\title{
$\frac{10}{9} \cdot 18.908 S D$ \\ SANDIA REPORT
}

SAND90-0163 $\cdot \mathrm{UC}-528$

Unlimited Release

Printed March 1990

\section{The Scalability of OTR Space Nuclear Power Systems}

Donald R. Gallup

\section{Prepared by}

Sandia National Laboratories

Albuquerque, New Mexico $\mathbf{8 7 1 8 5}$ and Livermore, California 94550

for the United States Department of Energy

under Contract DE-AC04-76DP00789

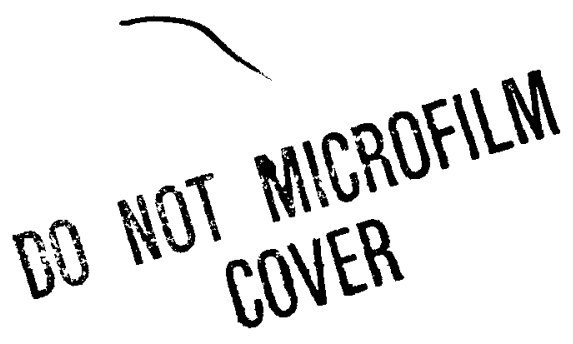




\section{DISCLAIMER}

This report was prepared as an account of work sponsored by an agency of the United States Government. Neither the United States Government nor any agency Thereof, nor any of their employees, makes any warranty, express or implied, or assumes any legal liability or responsibility for the accuracy, completeness, or usefulness of any information, apparatus, product, or process disclosed, or represents that its use would not infringe privately owned rights. Reference herein to any specific commercial product, process, or service by trade name, trademark, manufacturer, or otherwise does not necessarily constitute or imply its endorsement, recommendation, or favoring by the United States Government or any agency thereof. The views and opinions of authors expressed herein do not necessarily state or reflect those of the United States Government or any agency thereof. 


\section{DISCLAIMER}

Portions of this document may be illegible in electronic image products. Images are produced from the best available original document. 
Issued by Sandia National Laboratories, operated for the United States Department of Energy by Sandia Corporation.

NOTICE: This report was prepared as an account of work sponsored by an agency of the United States Government. Neither the United States Government nor any agency thereof, nor any of their employees, nor any of their contractors, subcontractors, or their employees, makes any warranty, express or implied, or assumes any legal liability or responsibility for the accuracy, completeness, or usefulness of any information, apparatus, product, or process disclosed, or represents that its use would not infringe privately owned rights. Reference herein to any specific commercial product, process, or service by trade name, trademark, manufacturer, or otherwise, does not necessarily constitute or imply its endorsement, recommendation, or favoring by the United States Government, any agency thereof or any of their contractors or subcontractors. The views and opinions expressed herein do not necessarily state or reflect those of the United States Government, any agency thereof or any of their contractors.

Printed in the United States of America. This report has been reproduced directly from the best available copy.

Available to DOE and DOE contractors from

Office of Scientific and Technical Information

PO Box 62

Oak Ridge, TN 37831

Prices available from (615) 576-8401, FTS 626-8401

Available to the public from

National Technical Information Service

US Department of Commerce

5285 Port Royal Rd

Springfield, VA 22161

NTIS price codes

Printed copy: A04

Microfiche copy: A01

\section{DO NOT MICROFILM THIS PAGE}


SAND90-0163

Unlimited Release

Printed March 1990
Distribution

Category UC-528

THE SCALABILITY OF OTR SPACE NUCLEAR POWER SYSTEMS

\author{
Donald R. Gallup \\ Space Power Systems Studies Division \\ Sandia National Laboratories SAND--90-0163 \\ Albuquerque, NM 87185 \\ DE9 0013553
}

\title{
DISCLAIMER
}

\begin{abstract}
This report was prepared as an account of work sponsored by an agency of the United States Government. Neither the United States Government nor any agency thereof, nor any of their employees, makes any warranty, express or implied, or assumes any legal liability or responsibility for the accuracy, completeness, or usefulness of any information, apparatus, product, or process disclosed, or represents that its use would not infringe privately owned rights. Reference herein to any specific commercial product, process, or service by trade name, trademark, manufacturer, or otherwise does not necessarily constitute or imply its endorsement, recommendation, or favoring by the United States Government or any agency thereof. The views and opinions of authors expressed herein do not necessarily state or reflect those of the United States Government or any agency thereof.
\end{abstract}

\section{ABSTRACT}

Masses of the STAR-C power system and an optimized OTR power system versus power level are investigated. The impacts of key system parameters on system performance are also addressed. The STAR-C is mass competitive below about $15 \mathrm{kWe}$, but at higher power levels the scalability is relatively poor. An optimized OTR is the least massive space nuclear power system below $25 \mathrm{kWe}$, and scales well to $50 \mathrm{kWe}$. The system parameters that have a significant impact on the scalability of the STAR-C are core thermal flux, thermionic converter efficiency, and core length to diameter ratio. The emissivity of the core surface is shown to be a relatively unimportant parameter. For an optimized OTR power system, the most significant system parameter is the maximum allowable fuel temperature. It is also shown that if advanced radiation-hardened electronics are used in the satellite payload, a very large mass savings is realized. 
BLANK 


\section{CONTENTS}

Abstract..............................

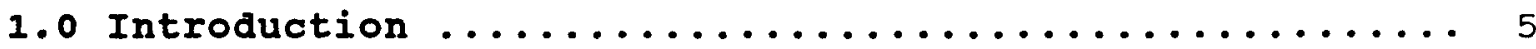

1.1 The STAR-C Power system................... 5

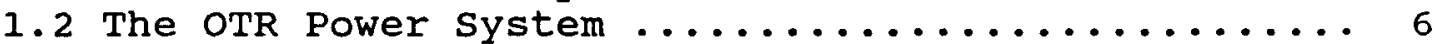

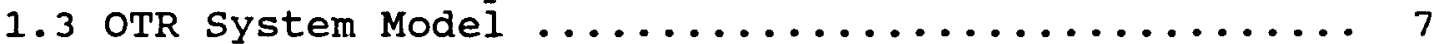

2.0 scalability of the star-c Power system ........... 14

2.1 Sandia Mass Estimates for STAR-C ............ 14

2.2 Comparison of Sandia and

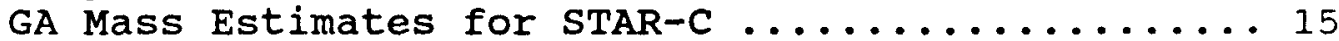

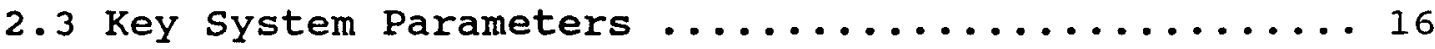

2.3.1 Core Thermal Flux .................. 16

2.3.2 Thermionic Converter Efficiency ......... 17

2.3.3 Emissivity of the Core surface ........... 18

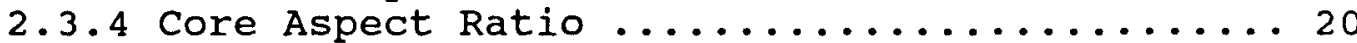

3.0 scalability of the OTR Power system $\ldots \ldots \ldots \ldots \ldots \ldots \ldots$

3.1 Mass Estimates for OTR Power systems .......... 36

3.2 Key system Parameters for OTRs .............. 37

3.2 .1 Emissivity of the core surface ......... 37

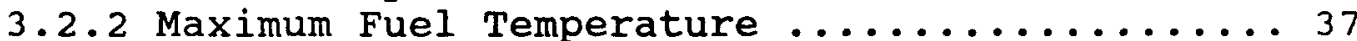

3.2.3 TI Converter Emitter Temperature ......... 38

3.2 .4 Thermal Conductivity of Graphite ......... 38

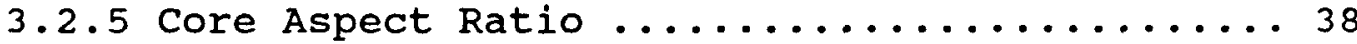

3.3 OTR Power System Design Changes ............ 38

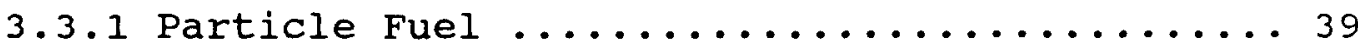

3.3.2 Advanced Rad-Hard Electronics ............ 40

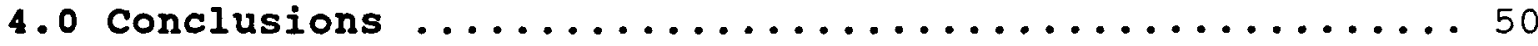

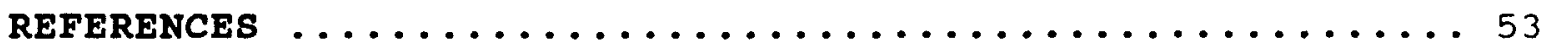

Appendix A: Input Parameters for the ............. 54

Appendix B: Example Input for the

Sandia OTR systems Model .............660

Appendix C: Example output from the

Sandia OTR systems Model .............6 63 


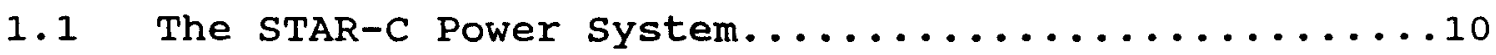

1.2 The Fuel Form For STAR-C --

Monolithic $\mathrm{UC}_{2}$ In Graphite Trays................11

1.3 Schematic Diagram of a STAR-C Thermionic Converter.12

1.4 Theoretical Efficiency of a ThermoElectron

Converter -- No Lead Losses..................13

2.1 Scalability of the STAR-C Power System with Power..25

2.2 Impact of Core Thermal Flux on

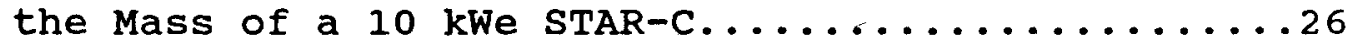

2.3 Impact of Core Thermal Flux on

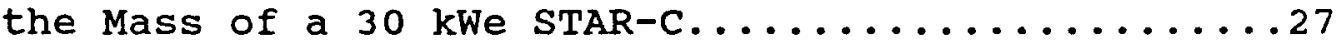

2.4 Impact of TI Converter Efficiency on

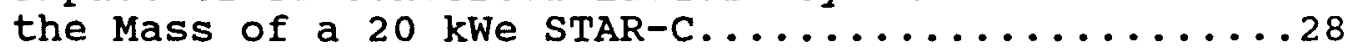

2.5 Impact of TI Converter Efficiency on

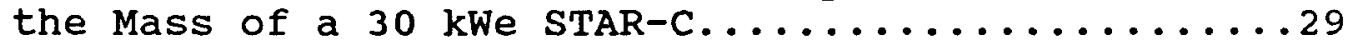

2.6 Impact of Core Surface Emissivity on

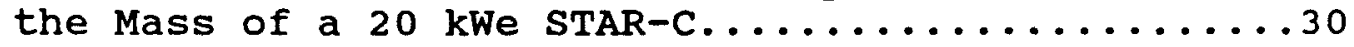

2.7 Impact of Core Surface Emissivity on

the Mass of a $20 \mathrm{kWe}$ STAR-C Using the

Wrong Approach, i.e., $\mathrm{T}_{\mathrm{CS}}=2000 \mathrm{~K} . \ldots \ldots \ldots . . . . .31$

2.8 Impact of Core Aspect Ratio on

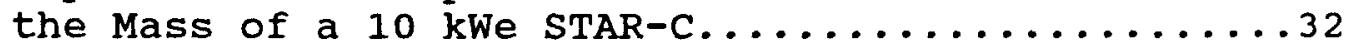

2.9 Impact of Core Aspect Ratio on

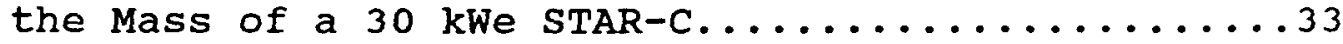

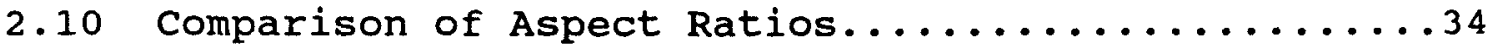

3.1 Scalability of the OTR and STAR-C Power Systems...41

3.2 Impact of Core Surface Emissivity on

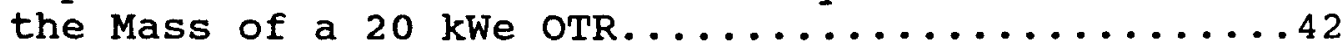

3.3 Impact of Maximum Fuel Temperature on

the Scalability of OTR Power Systems............43

3.4 Impact of TI Converter Emitter Temperature on

the Mass of a $20 \mathrm{kWe}$ OTR...................44 


\section{FIGURES}

3.5 Impact of Graphite Thermal Conductivity on

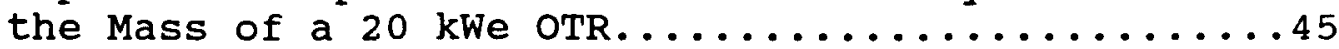

3.6 Impact of Core Aspect Ratio on

the Mass of a $30 \mathrm{kWe}$ OTR.................46

3.7 Impact of a Particle Fuel on the

scalability of Power systems...............47

3.8 Impact of Improved Rad-Hard Electronics on

the Scalability of an OTR Power system..........48

4.1 Comparison of the scalability of OTR

and STAR-C Power Systems with other

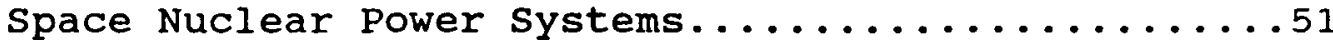

\section{TABLE8}

1.1 Key System Parameters For A $6 \mathrm{kWe}$

Star-C Power System (As Defined by Sandia)........8

1.2 Key System Parameters for a $30 \mathrm{kWe}$

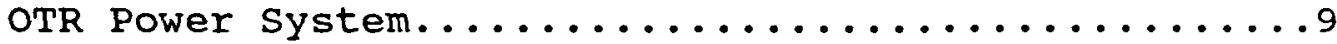

2.1 Sandia Mass Estimates For The

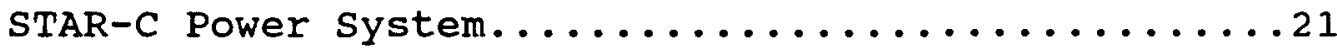

2.2 Comparison of Sandia Mass Estimates For

A 6 kWe STAR-C Power System For

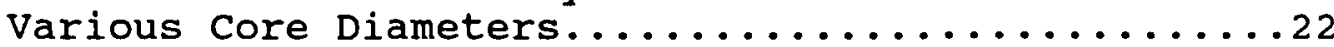

2.3 Comparison of Sandia Mass Estimates For

A $15 \mathrm{kWe}$ STAR-C Power System For

Various Core Diameters...................23

2.4 Comparison of The Sandia And GA Mass Estimates

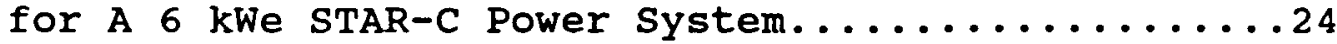

3.1 Sandia Mass Estimates For An Optimized

OTR Power System.......................4 40 


\subsection{Introduction}

For the past several years, the Air Force has been expressing an interest in space nuclear reactor power supplies for use with future satelitites. The power range of interest to the Air Force is 5 to $40 \mathrm{kWe}$. As a result, there have been new power system concepts proposed by industry that provide viable alternatives to the SP-100 power system, which was originally intended for use at higher power levels, e.g., $100 \mathrm{kWe}$. One of the concepts that has received considerable attention is the STAR-C power system, which is being proposed by GA Technologies (GA). Due to the attention received by STAR-C, the Air Force Space Technology Center (AFSTC) requested Sandia National Laboratories to investigate the viability of out-of-core thermionic reactor (OTR) power systems. OTR is a generic term for a STAR-C type power system.

This report presents the results of a study on the optimization of OTR power systems. The three primary objectives of the study were (1) to determine how well an oTR can scale with power level, (2) to determine the impact of key system parameters on OTR system performance, and (3) to compare the system performance of an optimized OTR power system with that of the STAR-C power system on a consistent basis.

A general description of the STAR-C and OTR power systems is given in sections 1.1 and 1.2 , and section 1.3 briefly discusses the system model used in this study. Chapter 2 discusses the scalability of the STAR-C power system and the impact of key system parameters on STAR-C. In chapter 3 the scalability and key system parameters of an optimized OTR are discussed. Chapter 4 presents the conclusions of this study.

\subsection{The STAR-C Power System}

The STAR-C power system, which is a specific version of an OTR power system, is described in detail in References 1 and 2. The STAR-C power system (Figure 1.1) is unique in that it is a totally static power system. The power that is generated in the reactor core is radiated radially across a small vacuum gap to the hot shoes of the thermionic (TI) converters. The TI converters, which are integrated into the reflector, produce electrical power by emitting electrons from the converter emitter to the converter collector, which are separated by a voltage potential. The waste heat is removed from the converter collector by a heat pipe, and is carried to the waste heat radiator, which surrounds the reactor. The satellite payload is protected from radiation emitted from the reactor by a radiation shield comprised of $\mathrm{ZrH}_{2}$ and $\mathrm{LiH}$. Key system parameters for a $6 \mathrm{kWe}$ STAR-C are given in Table 1.1 . 
The STAR-C reactor uses monolithic blocks of $\mathrm{UC}_{2}$ fuel that sit in graphite trays (Figure 1.2). The thickness of the $\mathrm{UC}_{2}$ is $1.6 \mathrm{~cm}$ and the ratio of the inner to outer fuel radius is 0.333 . The diameter of the reactor core is either 26 or $42 \mathrm{~cm}$; the diameter selected depends on the reactor power level. The core is built by stacking these trays on top of one another. Desired power and temperature profiles are obtained by varying the thickness of the graphite trays. The graphite trays are coated with NbC to prevent sublimation of the graphite and to retain the volatile fission products. The maximum temperature in the fuel is approximately $2300 \mathrm{~K}$, and the temperature at the radial core surface is $2000 \mathrm{~K}$. The thermal emissivity of the core surface is assumed to be 0.85 .

The TI converter used in the STAR-C power system is based on the SET converter, which was developed in a solar power program in the 1960s (Figure 1.3). The approximate emitter and collector temperatures of the converter are 1850 and $1000 \mathrm{~K}$, respectively. The efficiency at the electrical leads of the converter is $14.1 \%$. The waste heat produced by the converter is removed from the back side of the collector by an integral heat pipe. The heat is carried to the waste heat radiator, which surrounds the reactor, and radiated to space. The TI converters are integrated into the radial $\mathrm{Be}$ reflector, which surrounds the reactor core (Figure 1.1).

The satellite payload is protected from radiation emitted from the reactor by a radiation shield and a separation boom. The radiation shield is comprised of $\mathrm{ZrH}_{2}$ and $\mathrm{LiH}$. The $\mathrm{ZrH}_{2}$ is used for shielding against gamma rays, and the $L i H$ is for shielding against neutrons. For a given allowable total dose to the payload, the shield thickness and diameter, and thus mass, depend on the length of the separation boom. Power produced in the power system is carried down the boom by a transmission line, and then converted into the voltages required by the satellite by a power conversion system. (Note: The GA power system description stops at the back side of the shield; thus, the separation boom, transmission line, and power conditioning equipment are not included in their system description. It is included here to provide consistency with other power systems, e.g., the sp-100.)

\subsection{The OTR Power System}

out-of-core thermionic reactor is a general name that can be given to the STAR-C power system. It comes from the fact that the power is generated by TI converters that are external to the reactor core. By using the more general name, design changes can be made to investigate the use of different technologies and to optimize the power system without confusing the reader concerning the GA design. The two primary changes that have been made for the studies presented later in this report are (1) the reactor core 
dimensions are allowed to vary to obtain a minimum system mass, and (2) the thermionic converter used is based on data obtained from a ThermoElectron test converter (Figure 1.4) [3]. The system characteristics that are similar to the STAR-C include (1) the same fuel form, $\mathrm{UC}_{2}$ in graphite trays, is used, (2) the same shield materials, $\mathrm{LiH}$ and $\mathrm{ZrH}_{2}$, are used, and (3) the same reflector material, $\mathrm{Be}$, is used. The key system parameters for a $30 \mathrm{kWe}$ OTR power system are given in Table 1.2. (In future work, other system features, e.g., fuel form, will be varied.)

\subsection{OTR System Model}

The results presented in this study were obtained using an OTR system model developed at Sandia $[4,5,6]$. This model can be used to represent either the STAR-C power system or an OTR power system. When an OTR power system is modeled, key system parameters are varied to obtain the optimal system design based on total power system mass. When the STAR-C is modeled, the system parameters defined by GA are used, e.g., a ratio of the inner to outer fuel radius of 0.333 is used.

Although the entire Sandia OTR model has not yet been fully documented, the reactor and shield portion of the model are well documented in Reference 4 and 5 . A further indication of the level of detail the model contains can be obtained from the following considerations (1) the model contains over 2200 lines of FORTRAN coding and (2) almost 100 input parameters must be specified (Appendices $A$ and $B$ ). An example output from the system model is given in Appendix $C$.

One note of caution about the mass values obtained using the Sandia OTR model is needed. Specifically, at the higher power levels, i.e., above about $30 \mathrm{kWe}$, the waste heat radiator becomes so large that it cannot be located above the radiation shield without making design changes, e.g., increasing the diameter of the shield. The impact of these design changes is not included in the system mass. 
Table 1.1

Rey system Parameters For A 6 kWe 8TAR-C

Power system (As Defined By sandia)

system Parameter

Value

General

Net Electrical Power (kWe)

6

TI Converter Efficiency ( $\delta$ )

14.1

Net Electrical Efficiency ( $\%$ )

12.2

Temperatures (K)

Maximum Fuel

2290

Effective Core Surface

2000

TI Emitter

1863

TI Collector

1016

Dimensions (cm)

Core Length

35.9

Core Diameter

26.0

Inner Fuel Diameter

8.0

Outer Fuel Diameter

24.0

Masses (kg)

Reactor

455

Shield

389

Total system

1067 
Table 1.2

Rey system Parameters For A 30 kwe OTR Power system

System Parameter

Value

General

Net Electrical Power (kWe) 30

TI Converter Efficiency $(z)$

15.1

Net Electrical Efficiency ( $z)$

13.1

Temperatures (K)

Maximum Fuel

2300

Effective Core Surface

2112

TI Emitter

1900

TI Collector

1000

Dimensions $(\mathrm{cm})$

Core Length

77.6

Core Diameter

33.7

Inner Fuel Diameter

25.3

outer Fuel Diameter

31.4

Masses $(\mathrm{kg})$

Reactor

1052

Shield

394

Total system

1867 
Figure 1.1

\section{The STAR-C Power System}

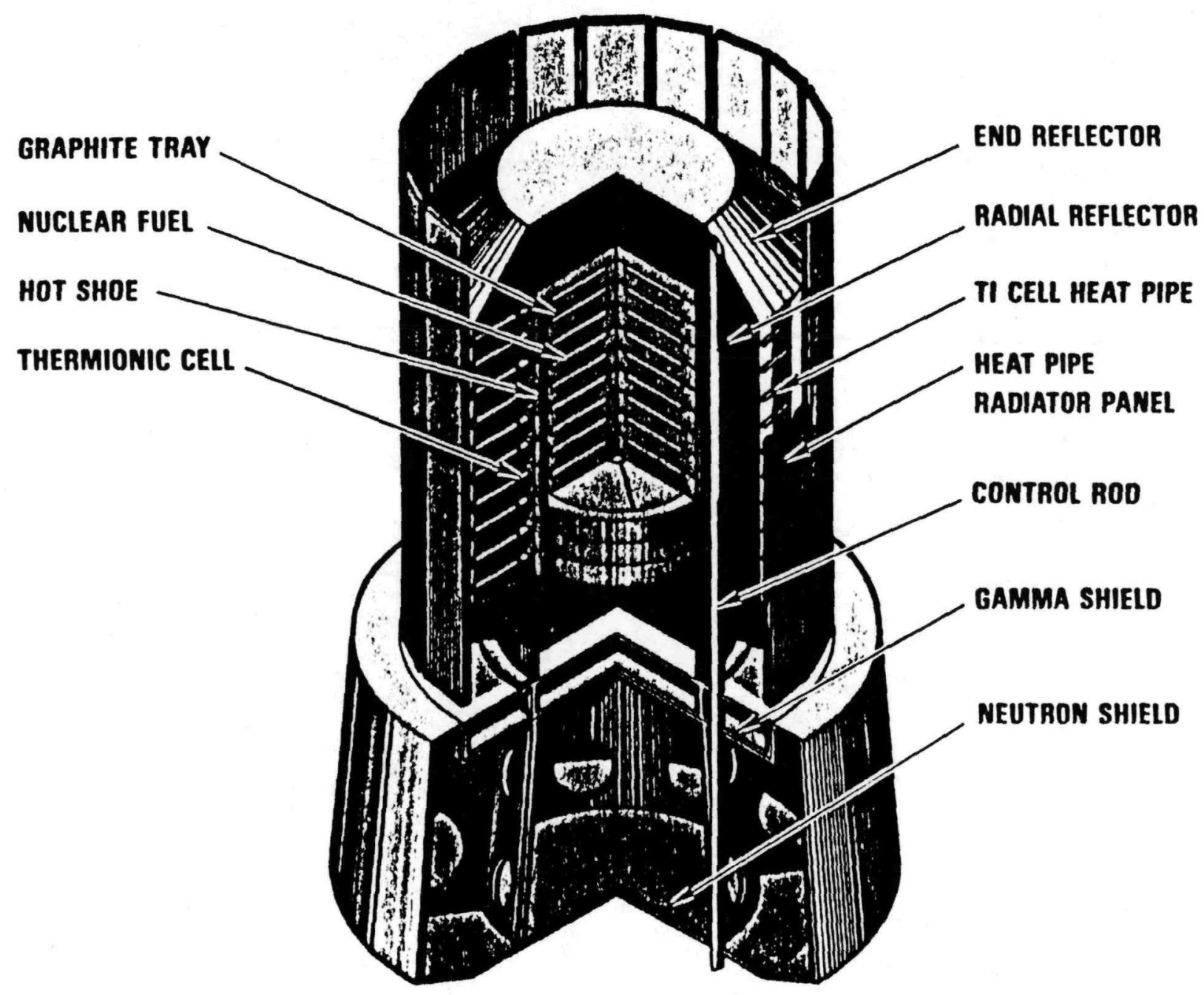




\section{Figure 1.2}

The Fuel Form For STAR-C -- Monolithic UC2 In Graphite Trays

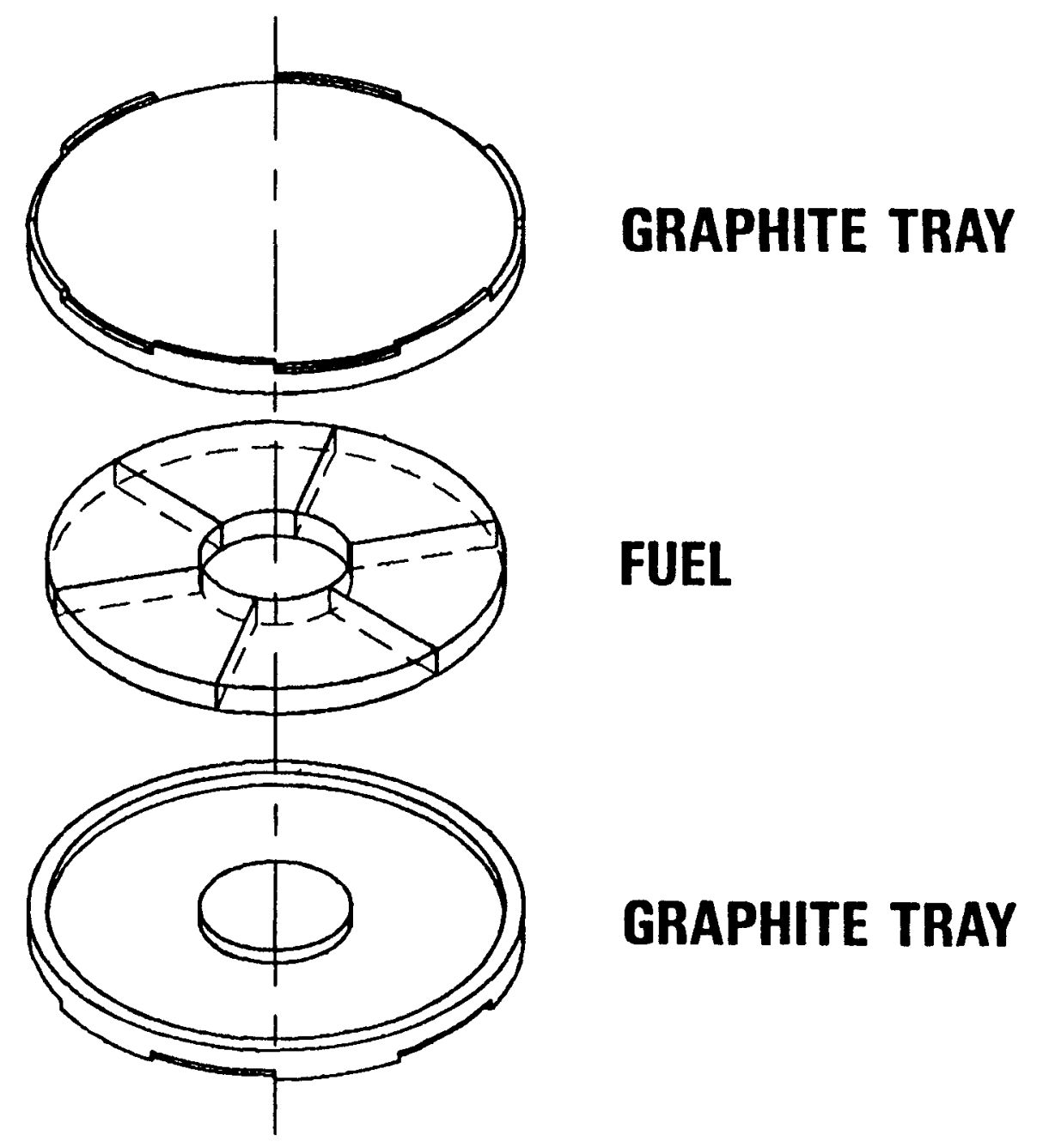




\section{Figure 1.3 Schematic Diagram of a STAR-C Thermionic Converter}

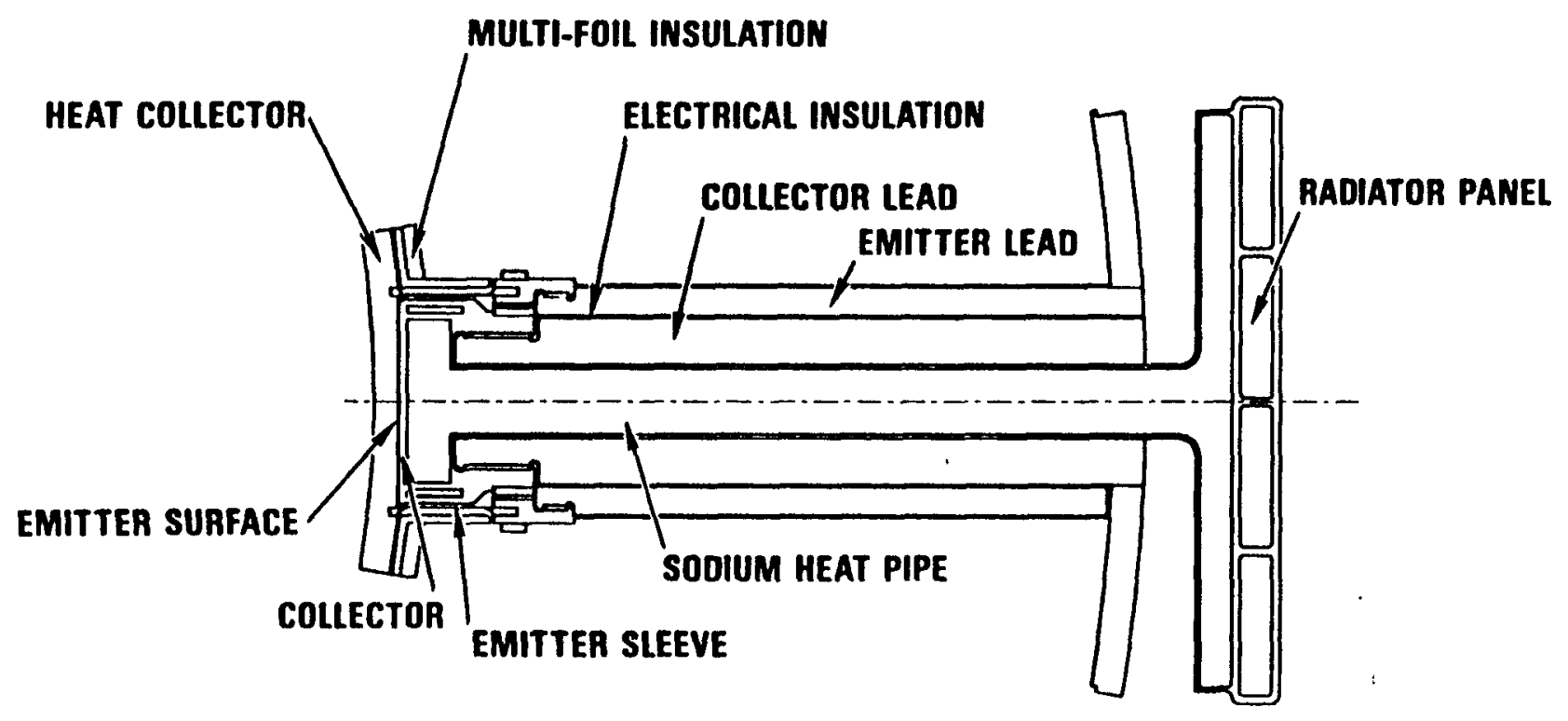


Figure 1.4

\section{Theoretical Efficiency of a ThermoElectron Converter -- No Lead Losses}

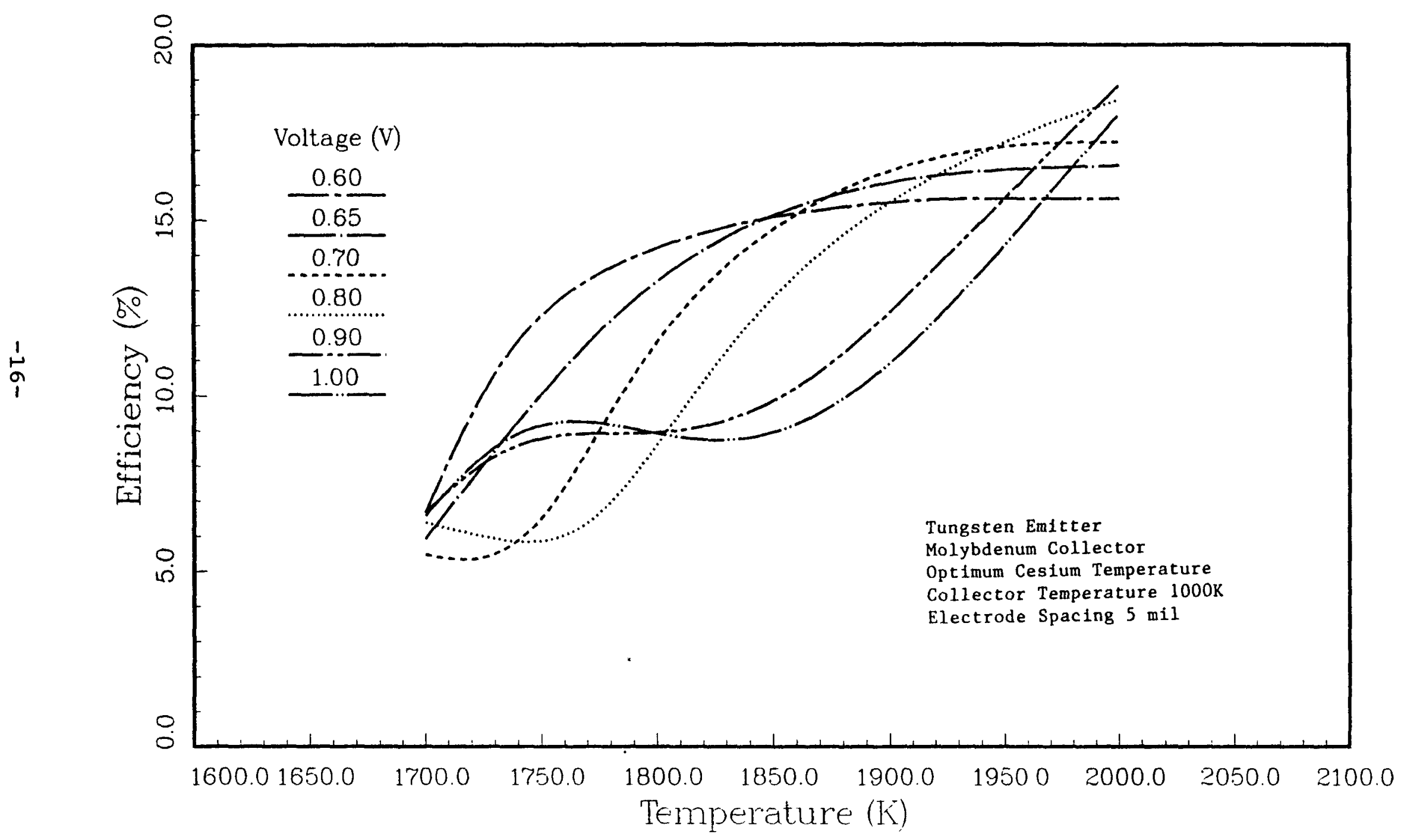




\subsection{Scalability of the sTAR-C Power system}

The Sandia OTR system model has been used to estimate the mass and impact of key system parameters on mass for the STAR-C power system. The mass estimates for the base case power systems are discussed in section 2.1. A comparison of the Sandia mass estimates with the mass estimates that have been made by GA Technologies is made in section 2.2. In Section 2.3 the significance of the assumed parameter values for the base case power systems discussed in section 2.1 is addressed. This is done by varying the parameter values over a wide range and assessing the change in the power system mass estimate.

\subsection{Sandia Mass Estimates for STAR-C}

The Sandia OTR system model has been used to calculate the mass and other system parameters of the STAR-C concept as described by GA Technologies in References 1 and 2 . The results of these mass calculations are given in Table 2.1 and plotted in Figure 2.1 as a function of power. Two sets of Sandia derived mass estimates are included. The first set is for reactor core dimensions as described by GA Technologies $[1,2]$, i.e., the core diameter is either $26 \mathrm{~cm}$ or $42 \mathrm{~cm}$ and the ratio of the inner to outer fuel radius is 0.333 , and this data is plotted as discrete points. The appropriate core diameter was selected based on two criteria (1) minimum system mass and (2) a maximum allowable core aspect ratio, i.e., core length to diameter ratio, of 3.0 . The second set of data is for an optimal core geometry, i.e., the core diameter is sized to minimize shield mass and the ratio of the inner to outer fuel radius is minimized to reduce the mass of fuel required, and this data is plotted as a solid line. For this set of data, the core length to diameter ratio was not allowed to exceed 2.5. (Note: All of the mass estimates for radiation shields presented in this report assume that the diameter of the payload is 4 meters and that the permissible radiation dose to the payload is 0.5 Mrad and 1013 nvt over a 10 year period. Boom length is optimized based on mass.) The solid line in Figure 2.1 does not represent a fully optimized system, primarily because the core thermal flux is held at $15.3 \mathrm{~W} / \mathrm{cm}^{2}$, which is the value derived from Reference 1. In Chapter 3, we will present Sandia's results for an OTR that is fully optimized to reduce power system mass.

As can be seen in Figure 2.1, it is important that the core dimensions be selected so as to minimize the power system mass as was done by Sandia. The power system mass can be reduced by as much as $20 \%$ by selecting the optimal core dimensions. The reason for the difference in mass between the two cases varies with power level. At $6 \mathrm{kWe}$, the reduction in mass is brought about primarily by a reduction in the mass of the radiation shield. This results from a 
reduction in the diameter, and thus volume, of the shield-the optimized reactor core has a smaller diameter than the GA specified diameter. A comparison of the mass breakdowns for 6 kWe power systems calculated using each of the methods described above is given in Table 2.2. At $15 \mathrm{kWe,} \mathrm{the}$ largest contributor to mass reduction for the optimized core geometry is the mass of the reactor itself. The reduction in reactor mass is a result of two factors. First, the optimized reactor has a larger aspect ratio: 2.5 as compared to 1.3. Since both systems require the same amount of surface area to convert the heat produced in the core to electricity via the thermionic converters, the volume of the optimized core is smaller. Second the ratio of the inner to outer fuel radius is larger for the optimized core configuration: 0.72 as compared to 0.33 . This results in a lower fraction of the core volume comprised of fuel, which has a much higher density than carbon, and so the average density of the core is smaller. The reduction in the radiation shield for the $15 \mathrm{kWe}$ system with the optimal core dimensions is also significant. As was the case for the $6 \mathrm{kWe}$ system, this is brought about by a reduction in the diameter, and thus volume, of the shield. A comparison of the mass breakdowns for the $15 \mathrm{kWe}$ systems with an optimized core geometry and a $42 \mathrm{~cm}$ diameter are presented in Table 2.3.

\subsection{Comparison of Sandia and GA Mass Estimates for STAR-C}

The mass estimates for the STAR-C power system discussed above are higher than the mass estimates that have been made by GA Technologies $[1,2]$. A comparison of the Sandia and GA mass estimates for a $6 \mathrm{kWe}$ power system is given in

Table 2.4. (The Sandia mass estimate is for a reactor with a $26 \mathrm{~cm}$ diameter core. Also, the mass breakdown is different than that given in Tables 2.2 and 2.3 , because GA has a different mass breakdown than Sandia.) The major differences in the two mass estimates are explained below.

The Sandia estimate for the reactor and thermionic converters is $25 \%$ higher than the GA estimate. This is brought about by the fact that GA does not include power losses in the transmission line and power conditioning system. As a result, GA uses a system efficiency of $13.5 \%$, whereas Sandia calculates an efficiency of $12.2 \%$. Another way of looking at this is that by the GA definition, the Sandia power system is actually a $6.8 \mathrm{kWe}$ system. In either case, the Sandia reactor requires a larger length to produce the necessary power. This additional length results in additional mass. The GA mass estimate for the instrumentation and control (I\&C) is about $100 \mathrm{~kg}$ lower than the Sandia estimate. This is a result of two factors. First, the GA mass estimate does not include instrumentation. Second, in the control system GA assumes the use of innovative control rod drives and Sandia assumes drives based on the technology being 
developed in the SP-100 program. Sandia estimates the mass of the safety systems to be $59 \mathrm{~kg}$. The safety systems include a re-entry heat shield and safety rods and drives. $G A$ has no mass allocation for safety systems. The mass of the Sandia radiation shield is $28 \mathrm{~kg}$ less than the GA shield. This is due in part to the fact that the GA shield was for a payload diameter of 4.5 meters and the Sandia shield assumed a 4.0 meter diameter payload. Different shield thicknesses could also contribute to the mass difference. The mass estimates for the electrical subsystems is different, because the GA and Sandia definitions for this subsystem are different. GA only has one component in their estimate: a dc-dc amplifier that boosts the voltage before the power is transmitted down the boom. The Sandia electrical subsystem consists of electrical straps that connect the thermionic converters, a transmission line for carrying the power down the boom, a power conditioning system to convert the power to the proper voltages for a prototypic payload, and a radiator for the power conditioning equipment. The final reason for the large difference between the GA and Sandia mass estimates is that the Sandia estimate includes the mass of the boom that separates the reactor from the payload.

A calculation was made using the Sandia OTR model for a $6 \mathrm{kWe}$ STAR-C and assuming an overall system efficiency of $13.5 \%$, which corresponds to the value used by GA. When the masses of the power conditioning system and separation boom are ignored as was done by GA, the system mass is estimated to beat $845 \mathrm{~kg}$ compared to $714 \mathrm{~kg}$ calculated by GA. In this very comparable situation, almost the entire difference can be attributed to the difference in the mass estimates for the I\&C system. This discrepancy needs to be resolved.

\subsection{Key System Parameters}

There are several key system parameters that can have a significant impact on the masses of the STAR-C power systems that were presented in section 2.1. Four of these parameters and their impact on the base case system masses are discussed below. The masses presented below are for optimal core dimensions as calculated by sandia, i.e., they are variations of the mass estimates that produced the solid line in

Figure 2.1.

\subsubsection{Core Thermal Flux}

One of the most important parameters in the design of the STAR-C power system is the core thermal flux, $\phi$ th. This is particularly true for power levels above 8 to $10 \mathrm{kWe}$. The basis for the significance of the core thermal flux is as follows. Once the size of the reactor core is large enough to be above the criticality limit, its size becomes limited by thermal considerations. Specifically, the useful power 
produced in the core must be radiated across a small gap to the hot shoe of the thermionic converter. If the electrical power flux across the TI converter is less than the core thermal flux, which will always be the case for a reasonable design, it can be shown that the required surface area of the core, $A_{C S}$ is given by:

$$
A_{c s}=\frac{P_{e}}{\eta_{T I}{ }^{\phi} h^{\eta} e}
$$

where

$$
\begin{aligned}
\phi_{t h} & =\text { Core Thermal Flux }\left(\mathrm{W} / \mathrm{cm}^{2}\right) \\
\mathrm{P}_{\mathrm{e}} & =\text { Electrical Power }(\mathrm{W}) \\
\eta_{\mathrm{TI}} & =\text { Efficiency of the Thermionic Converters } \\
\eta_{\mathrm{e}} & =\text { Efficiency of the Electrical Subsystem }
\end{aligned}
$$

This equation shows that as the electrical power of the system increases, the core surface area increases. If the aspect ratio of the core, $i . e .$, the ratio of the core length to diameter, is limited to a reasonable value, then the volume and mass of the core will increase with the core surface area. (The aspect ratio was limited to 2.5 for the calculations presented in this report.)

Figures 2.2 and 2.3 show how the mass of the STAR-C power system varies with core thermal flux for 10 and 30 kWe power levels, respectively. It should be noted that the value used for the base case is $15.3 \mathrm{~W} / \mathrm{cm}^{2}$ and is noted on the figures by a solid dot. This value was calculated from data presented in Reference 1. For a $10 \mathrm{kWe}$ STAR-C, the mass will significantly increase if the thermal flux falls below 15.3 $\mathrm{W} / \mathrm{cm}^{2}$; the system mass increases by almost $15 \%$ if the flux drops to $12 \mathrm{~W} / \mathrm{cm}^{2}$. Doubling the thermal flux to $30 \mathrm{~W} / \mathrm{cm}^{2}$ decreases the total system mass by $15 \%$. For a $30 \mathrm{kWe}$ STAR-C, the system mass increases by $20 \%$ if the flux drops to 12 $\mathrm{W} / \mathrm{cm}^{2}$; and if the flux is doubled to $30 \mathrm{~W} / \mathrm{cm}^{2}$, the system mass drops by $32 \%$. So at the higher power levels, it is more important to optimize this thermal flux.

\subsubsection{Thermionic Converter Efficiency}

The efficiency of the thermionic converter is another very important parameter for the STAR-C power system. As can be seen from Equation 2.1 , it has the same relationship to the required core surface area as does the core thermal flux. 
Figures 2.4 and 2.5 show how total system mass varies with converter efficiency for 10 and $30 \mathrm{kWe}$ power systems, respectively. The base case efficiency is $14.1 \%[1,2]$, and is indicated on the figures by a solid dot. If the converter efficiency for a $10 \mathrm{kWe}$ system drops to $12 \%$, the system mass goes up by $11 \%$. If the efficiency goes up to $16 \%$, the system mass drops by $7 \%$. For a $30 \mathrm{kWe}$ STAR-C, the system mass goes up by $14 \%$ if the converter efficiency goes down to $12 \%$, and the mass goes down by $10 \%$ if the converter efficiency increases to $16 \%$. Again the effect is greater at higher power levels, but the mass decrease permitted by higher thermionic device efficiency is moderate.

\subsubsection{Emissivity of the Core Surface}

The emissivity of the core surface is another system parameter that can impact the mass of a STAR-C power system. It has inappropriately received a lot of attention as being a weak link in the STAR-C design. The core surface emissivity is an important parameter, because it impacts the core thermal flux:

$$
\phi_{\mathrm{th}}=\frac{{ }^{\varepsilon} \mathrm{cs}^{\varepsilon} \mathrm{hs}^{\sigma}\left(\mathrm{T}_{\mathrm{Cs}^{4}}-\mathrm{T}_{\mathrm{hs}}^{4}\right)}{\mathrm{cs}^{+\varepsilon} \mathrm{hs}^{-\varepsilon} \mathrm{cs}^{\varepsilon} \mathrm{hs}}
$$

where

$$
\begin{aligned}
{ }_{\mathrm{cs}} & =\text { Emissivity of the core surface } \\
{ }_{\mathrm{hs}} & =\text { Emissivity of the Hot Shoe of the TI Converter } \\
\mathrm{T}_{\mathrm{cs}} & =\text { Temperature of the Core Surface }(\mathrm{K}) \\
\mathrm{T}_{\mathrm{hs}} & =\text { Temperature of the Hot Shoe of the } \mathrm{TI} \text { Converter } \\
\sigma & =\text { stefan-Boltzman constant }\left(5.67 \times 10^{-12} \mathrm{~W} / \mathrm{cm}^{2} \mathrm{~K}^{4}\right)
\end{aligned}
$$

It should be noted from the above equation that the impact of hot shoe emissivity and core surface emissivity on thermal flux are identical. Figure 2.6 shows the significance of core surface emissivity on a $20 \mathrm{kWe}$ STAR-C. The solid dot shows the base case: $\varepsilon_{c s}=\varepsilon h s=0.85$. The important point to be made from Figure 2.6 is that the core surface emissivity does not have a major impact on the mass of STAR-C; if the core surface and hot shoe emissivities both drop to 0.7 , the mass of the power system will increase by only $6 \%$.

Figure 2.6 was obtained using Equation 2.2 to calculate the core thermal flux, and the following (one-dimensional) equation to calculate the core surface temperature, $\mathrm{T}_{\mathrm{CS}}$ : 


$$
\begin{aligned}
T_{c s}=T_{f m}-\frac{q_{v} r_{i}^{2}}{4 k_{f}}\left[\left(\frac{r_{o}}{r_{i}}\right)^{2}-2 \ln \left(\frac{r_{o}}{r_{i}}\right)-1\right] \\
\left.-\frac{q_{v} r_{i}^{2}}{2 k_{g}}\left[\frac{r_{o}}{r_{i}}\right]^{2}-1\right] \ln \left(\frac{r_{o}+t_{g}}{r_{0}}\right)
\end{aligned}
$$

where

$$
\begin{aligned}
& \mathrm{T}_{\text {fm }}=\text { Maximum Fuel Temperature (K) } \\
& \mathrm{q}_{\mathrm{v}}=\text { Volumetric Heat source in Fuel }\left(\mathrm{w} / \mathrm{cm}^{3}\right) \\
& k_{f}=\text { Thermal Conductivity of the Fuel Region (W/cmK) } \\
& \mathrm{k}_{\mathrm{g}}=\text { Thermal Conductivity of the Graphite }(\mathrm{W} / \mathrm{cmK}) \\
& r_{0}=\text { outer Radius of the Fuel Ring (cm) } \\
& r_{i}=\text { Inner Radius of the Fuel Ring (cm) } \\
& t_{g}=\text { Thickness of the Graphite Ring Around the Fuel (cm) }
\end{aligned}
$$

The Sandia OTR system model uses Equations 2.2 and 2.3 to obtain the values of $T_{C S}$ and $\phi_{t h}$ that are used to size the reactor.

The key point to note about Equations 2.2 and 2.3 is that the thermal calculations for the STAR-C are based on a maximum fuel temperature of $2300 \mathrm{~K}$ (and a ratio of inner to outer fuel radius of 0.333 ). The significance of basing the thermal calculations on constant fuel dimensions and a maximum fuel temperature while allowing all other parameter to vary can be explained in the following simplistic manner. If there is a drop in the core surface emissivity, which will result in a drop in the core thermal flux (the thermal flux radiated from the core surface to the thermionic diode hot shoes), the reactor thermal power, i.e., the volumetric heat source, $q_{v}$, must be lowered to prevent over-heating because less heat is leaving the core. However, a smaller volumetric heat source results in an increase in the core surface temperature (Equation 2.3), and this increase in core surface temperature results in a higher core thermal flux (Equation 2.2). Thus, a drop in core emissivity will be compensated for by re-designing with an increase in the core surface temperature while keeping the maximum fuel temperature constant. For example, the base case $20 \mathrm{kWe}$ STAR-C has the following operating parameters: $\varepsilon$ cs $=\varepsilon$ hs $=0.85$, $\phi_{\mathrm{th}}=15.3 \mathrm{~W} / \mathrm{cm}^{2}, q_{\mathrm{v}}=1.00, \mathrm{~T}_{\mathrm{Cs}}=2000 \mathrm{~K}, \mathrm{~T}_{\mathrm{fm}}=2300 \mathrm{~K}$. If the core surface and hot shoe emissivities were both reduced to 0.70 , then the system would 
be redesigned with the following operating parameters: $\phi_{t h}=13.8 \mathrm{~W} / \mathrm{cm}^{2}, q_{\mathrm{V}}=0.90, \mathrm{~T}_{\mathrm{Cs}}=2032 \mathrm{~K}, \mathrm{~T}_{\mathrm{fm}}=2300 \mathrm{~K}$. This $10 \%$ drop in the core thermal flux (and volumetric heat source) means that the core length must be increased by $11 \%$ to keep the output power constant at $20 \mathrm{kWe}$. This increase in reactor size and the concomitant increase in shield size result in a larger system mass; the mass increases from $1918 \mathrm{~kg}$ to $2038 \mathrm{~kg}$. So the system can be designed to utilize lower core or hot shoe emissivities without severe mass penalties, and degradation of surface emissivity during operation only produces a minimal decrease in output power.

It should be noted that the reason the STAR-C power system was thought to be very sensitive to core surface emissivity is that previous calculations were performed assuming the core surface temperature was held at $2000 \mathrm{~K}$ rather than being calculated using Equation 2.3. Figure 2.7 shows the sensitivity of system mass for this case. If the core surface and hot shoe emissivities both drop to 0.7, the mass of the system increases by $22 \%$.

\subsubsection{Core Aspect Ratio}

The core aspect ratio is a fourth parameter that can have a significant impact on the mass of a STAR-C power system. As was discussed in section 2.2 .1 , the core aspect ratio has an impact on the core mass required to obtain the necessary core surface area. In addition, the aspect ratio also has an impact on the mass of the radiation shield--a small aspect ratio tends to increase the diameter of the shield. Figures 2.8 and 2.9 show the impact of aspect ratio on system mass for 10 and $30 \mathrm{kWe}$ systems, respectively. (Unless otherwise stated, the maximum aspect ratio allowed in the calculations presented elsewhere in this report is 2.5 , and this value is indicated in the figures by a solid dot. The value 2.5, although somewhat arbitrary, was selected as a maximum value based on the potential difficulties that could be encountered with core retention and the need to maintain a gap between the core and TI hot shoe surface. Figure 2.10 visually represents various aspect ratios.)

If the assumption that the aspect ratio can be 2.5 is optimistic and the actual maximum value is 2.0 , then the mass of the $10 \mathrm{kWe}$ system increases by $5 \%$ and the mass of the $30 \mathrm{kWe}$ system increases by $7 \%$. On the other hand, if the aspect ratio can be increased to 3.0 , the masses of the 10 and $30 \mathrm{kWe}$ systems decrease by $3 \%$ and $5 \%$, respectively. A unique characteristic of Figure 2.8 is that as the aspect ratio of the $10 \mathrm{kWe}$ system increases above 4.0 , the mass of the power system increases. This can be attributed to the fact that the large aspect ratio causes the reactor mass to be driven by criticality concerns rather than by the core surface area. 
Table 2.1

Bandia Mass Estimates For The sTAR-C Power system

\begin{tabular}{ccc} 
& \multicolumn{2}{c}{ Mass (kg) } \\
\cline { 2 - 3 } Power & 26 or $42 \mathrm{~cm}$ & $\begin{array}{c}\text { Optimal Core } \\
\text { Diameter }\end{array}$ \\
\hline & Core Diameter & \\
5 & 1013 & 904 \\
6 & 1067 & 945 \\
8 & --- & 1077 \\
10 & 1260 & 1203 \\
15 & 1997 & 1590 \\
20 & 2313 & 1918 \\
30 & 2975 & 2639 \\
40 & $(1)$ & 3431 \\
50 & $(1)$ & 4245
\end{tabular}

(1) Core Aspect Ratio Exceeds 3.0 For A $42 \mathrm{~cm}$ Diameter Core 
Table 2.2

Comparison of sandia Mass Estimates For A 6 kWe STAR-C

Power system For Various Core Diameters

\begin{tabular}{|c|c|c|c|c|}
\hline \multirow[b]{2}{*}{ Component } & \multicolumn{4}{|c|}{ Mass $(\mathrm{kg})$} \\
\hline & $\operatorname{core}^{2}$ & cm & $\begin{array}{c}15 \\
\operatorname{core}\end{array}$ & $\begin{array}{l}.9 \mathrm{~cm} \\
\text { Diameter }\end{array}$ \\
\hline \multicolumn{5}{|l|}{ Reactor } \\
\hline Fuel & 88 & & 76 & \\
\hline Moderator & 22 & & 16 & \\
\hline structure & 23 & & 17 & \\
\hline Reflector & 108 & & 103 & \\
\hline Total & & 241 & & 211 \\
\hline Inst \& Control & & 138 & & 131 \\
\hline \multicolumn{5}{|l|}{ Safety systems } \\
\hline Re-entry Shield & 18 & & 14 & \\
\hline Rods \& Drives & 41 & & 38 & \\
\hline Total & & 59 & & 52 \\
\hline \multicolumn{5}{|l|}{ Shield } \\
\hline Neutron & 134 & & 105 & \\
\hline Gamma & 255 & & 207 & \\
\hline Total & & 389 & & 312 \\
\hline Thermionics & & 35 & & 35 \\
\hline \multicolumn{5}{|l|}{ Electrical subsystem } \\
\hline Power Cond & 11 & & 11 & \\
\hline PC Radiator & 3 & & 3 & \\
\hline PC Rad Shield & 4 & & 4 & \\
\hline TI straps & 22 & & 22 & \\
\hline Trans Line & 55 & & 55 & \\
\hline Total & & 96 & & 96 \\
\hline Radiator & & 18 & & 18 \\
\hline Boom & & 90 & & 90 \\
\hline Total system & & 1067 & & 945 \\
\hline
\end{tabular}


Table 2.3

Comparison of Sandia Mass Estimates For A 15 kWe STAR-C Power system For Various Core Diameters

\begin{tabular}{|c|c|c|c|c|}
\hline \multirow[b]{2}{*}{ Component } & \multicolumn{4}{|c|}{ Mass (kg) } \\
\hline & core & $\begin{array}{l}12 \mathrm{~cm} \\
\text { Diameter }\end{array}$ & core & $\begin{array}{l}0.6 \mathrm{~cm} \\
\text { Diameter }\end{array}$ \\
\hline \multicolumn{5}{|l|}{ Reactor } \\
\hline Fuel & 318 & & 124 & \\
\hline Moderator & 104 & & 84 & \\
\hline structure & 98 & & 66 & \\
\hline Reflector & 222 & & 202 & \\
\hline Total & & 743 & & 478 \\
\hline Inst \& control & & 223 & & 199 \\
\hline \multicolumn{5}{|l|}{ Safety systems } \\
\hline Re-entry Shield & 33 & & 22 & \\
\hline Rods \& Drives & 65 & & 59 & \\
\hline Total & & 99 & & 81 \\
\hline \multicolumn{5}{|l|}{ Shield } \\
\hline Neutron & 168 & & 137 & \\
\hline Gamma & 304 & & 191 & \\
\hline Total & & 471 & & 328 \\
\hline Thermionics & & 88 & & 87 \\
\hline \multicolumn{5}{|l|}{ Electrical subsystem } \\
\hline Power Cond & 23 & & 25 & \\
\hline PC Radiator & 8 & & 8 & \\
\hline PC Rad Shield & 4 & & 4 & \\
\hline TI straps & 55 & & 36 & \\
\hline Trans Line & 76 & & 136 & \\
\hline Total & & 166 & & 210 \\
\hline Radiator & & 46 & & 46 \\
\hline Boom & & 162 & & 162 \\
\hline Total system & & 1997 & & 1590 \\
\hline
\end{tabular}


Table 2.4

Comparison of The sandia And GA Mass Estimates

For A 6 kwe staR-C power system

\begin{tabular}{lcc} 
& \multicolumn{2}{c}{ Mass Estimate (kg) } \\
\cline { 2 - 3 } subsystem & sandia & GA \\
\hline Reactor and TI's & 276 & 221 \\
Instrumentation \& Control & 138 & 38 \\
Safety & 59 & --- \\
Radiation Shield & 389 & 417 \\
Electrical & 96 & 5 \\
Waste Heat Rejection & 18 & 33 \\
Separation Boom & 90 & --- \\
$\quad$ Total & 1067 & 714
\end{tabular}




\section{Figure 2.1 \\ Scalability of the STAR-C Power System With Power}

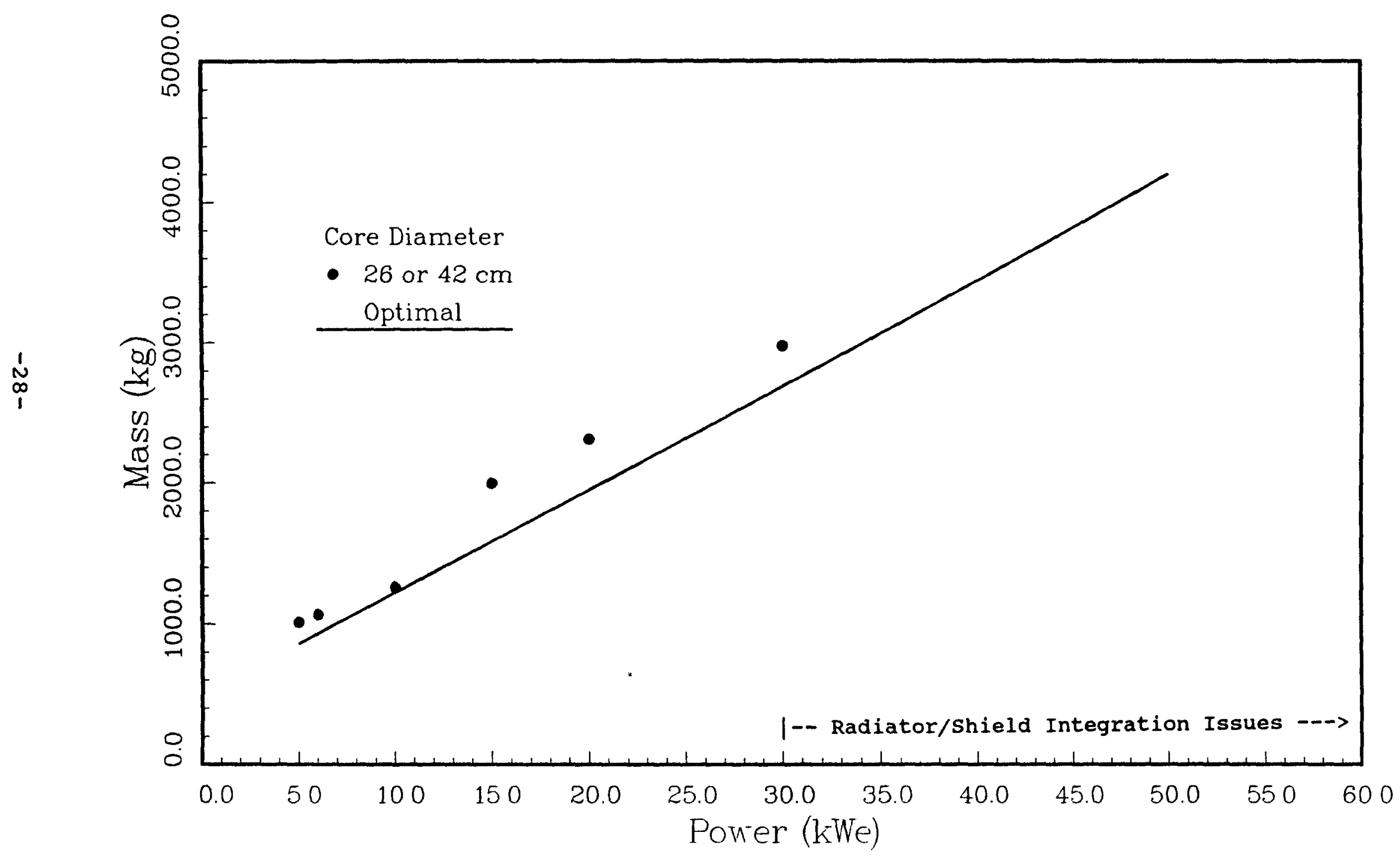


Figure 2.2

\section{Impact of Core Thermal Flux on the}

Mass of a $10 \mathrm{kWe}$ STAR-C

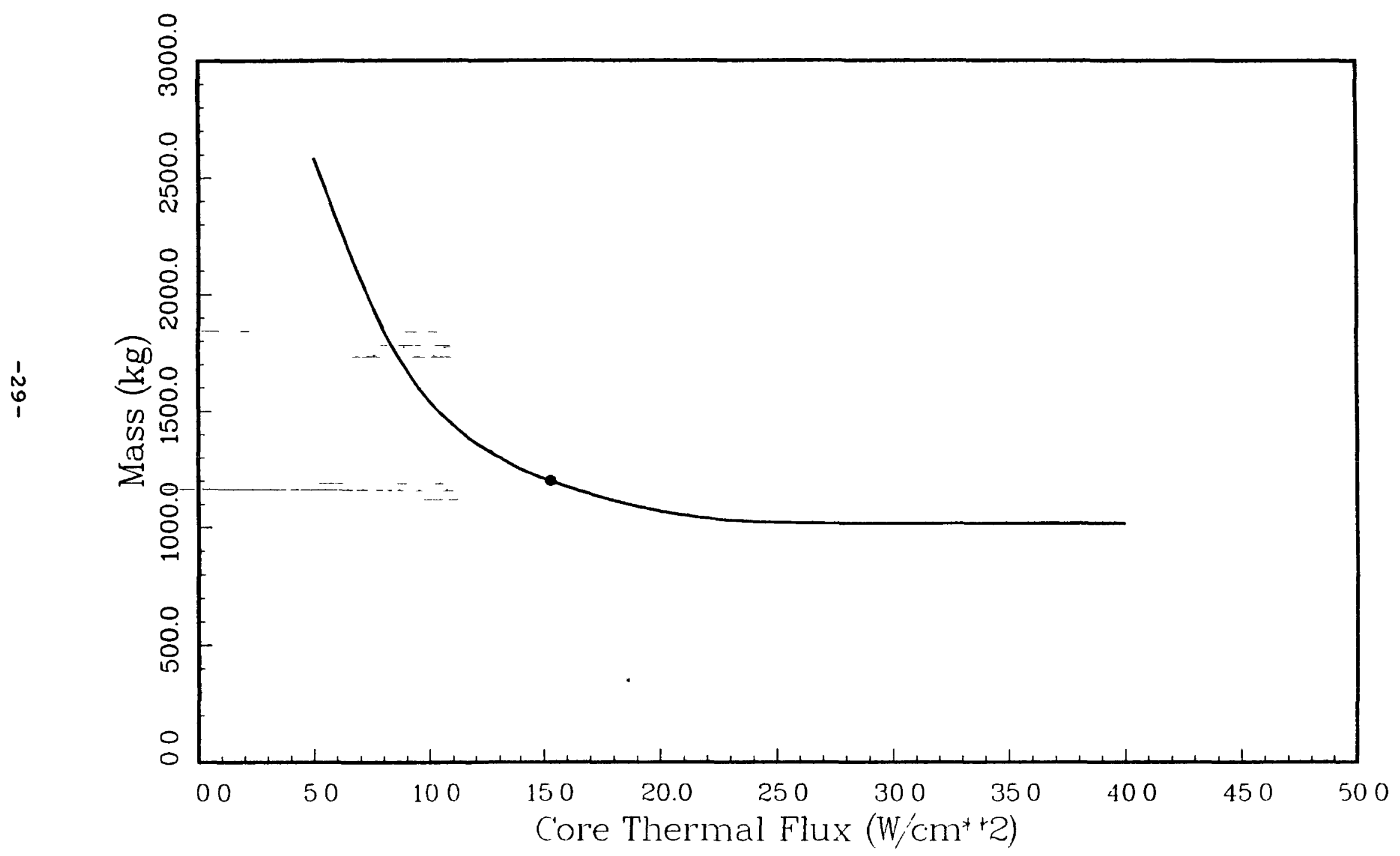


Figure 2.3

\section{Impact of Core Thermal Flux on the Mass of a $30 \mathrm{kWe}$ STAR-C}

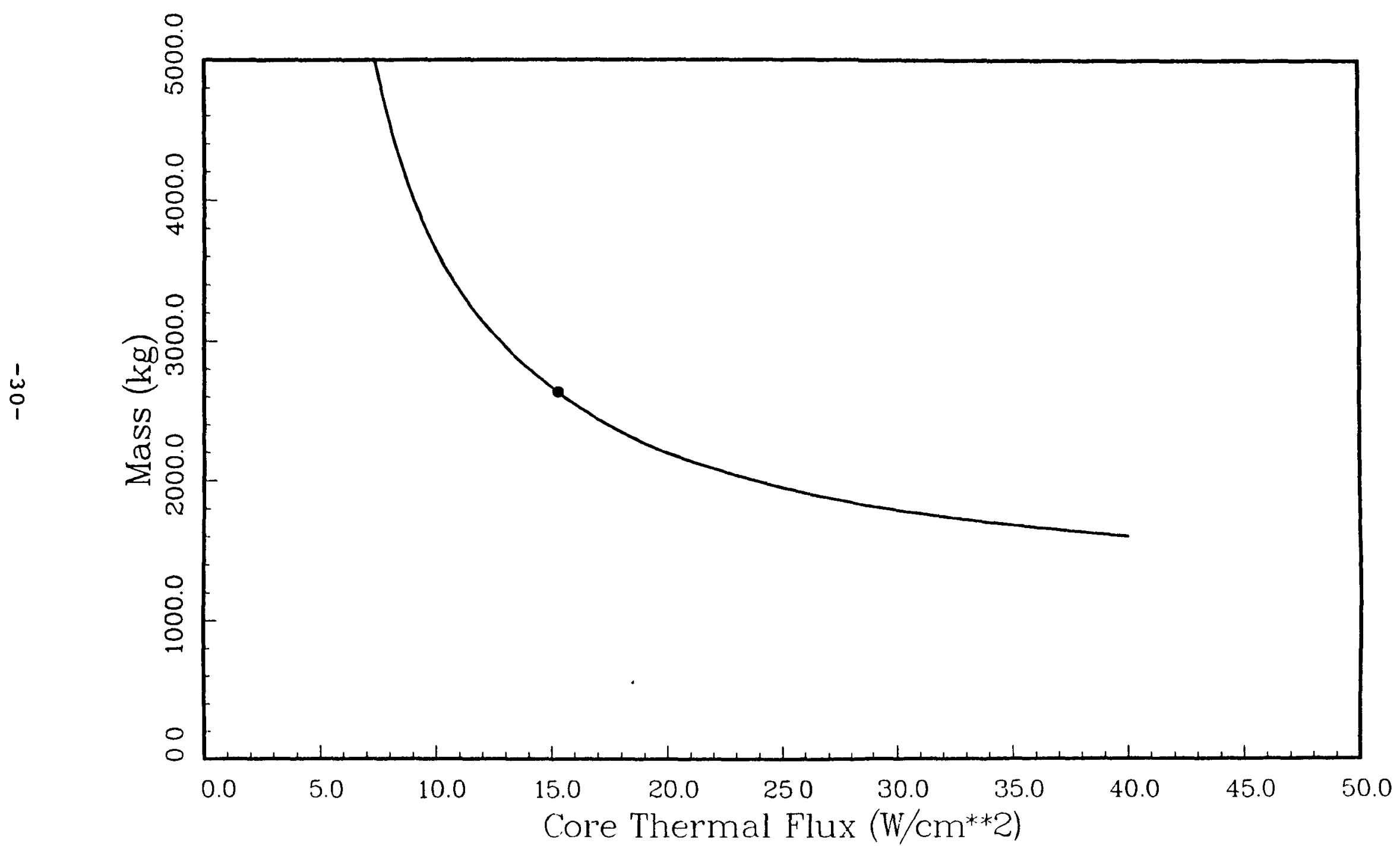


Figure 2.4

Impact of TI Converter Efficiency on the

Mass of a $10 \mathrm{kWe}$ STAR-C

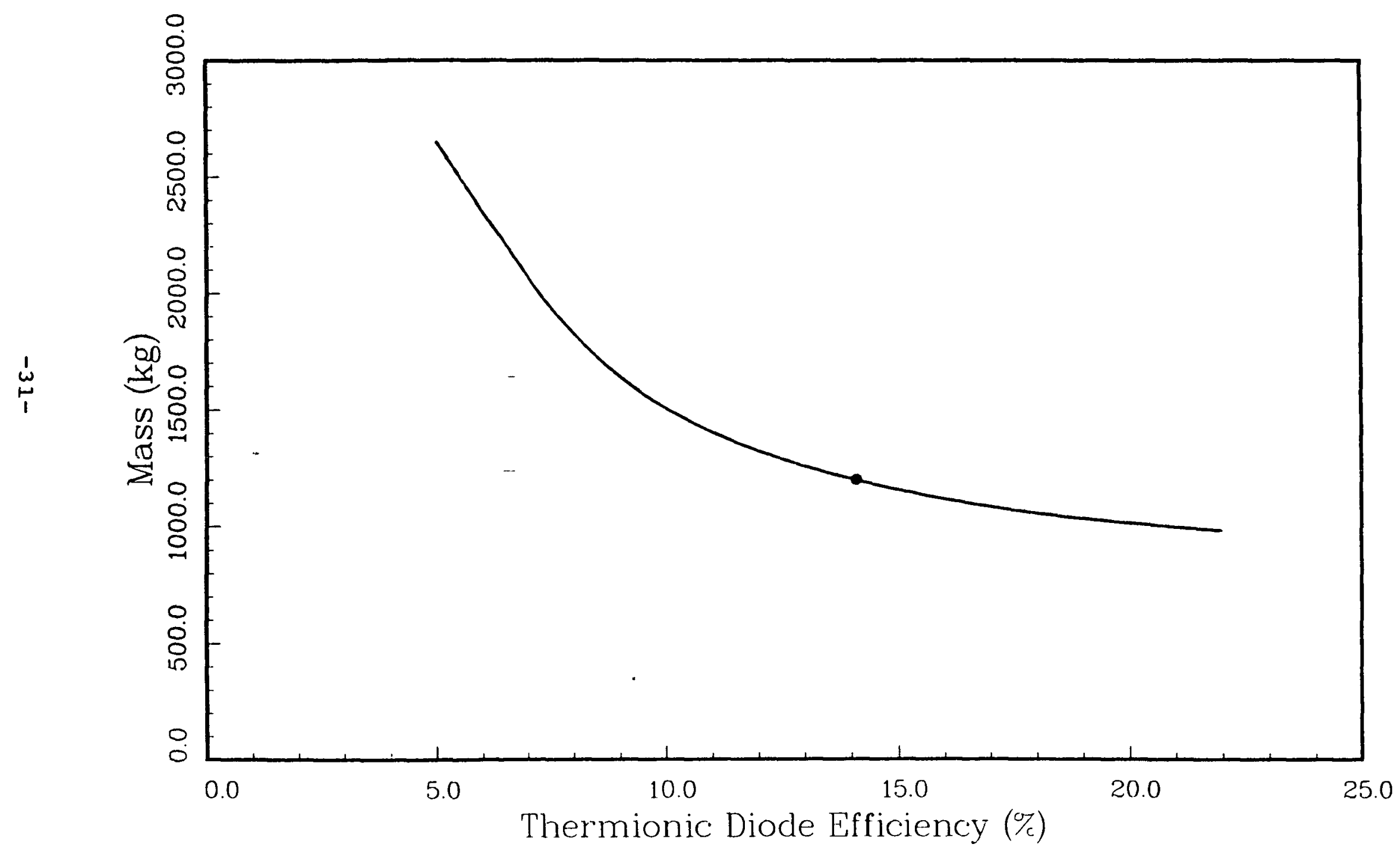


Figure 2.5

Impact of TI Converter Efficienty on the

Mass of a $30 \mathrm{kWe}$ STAR-C

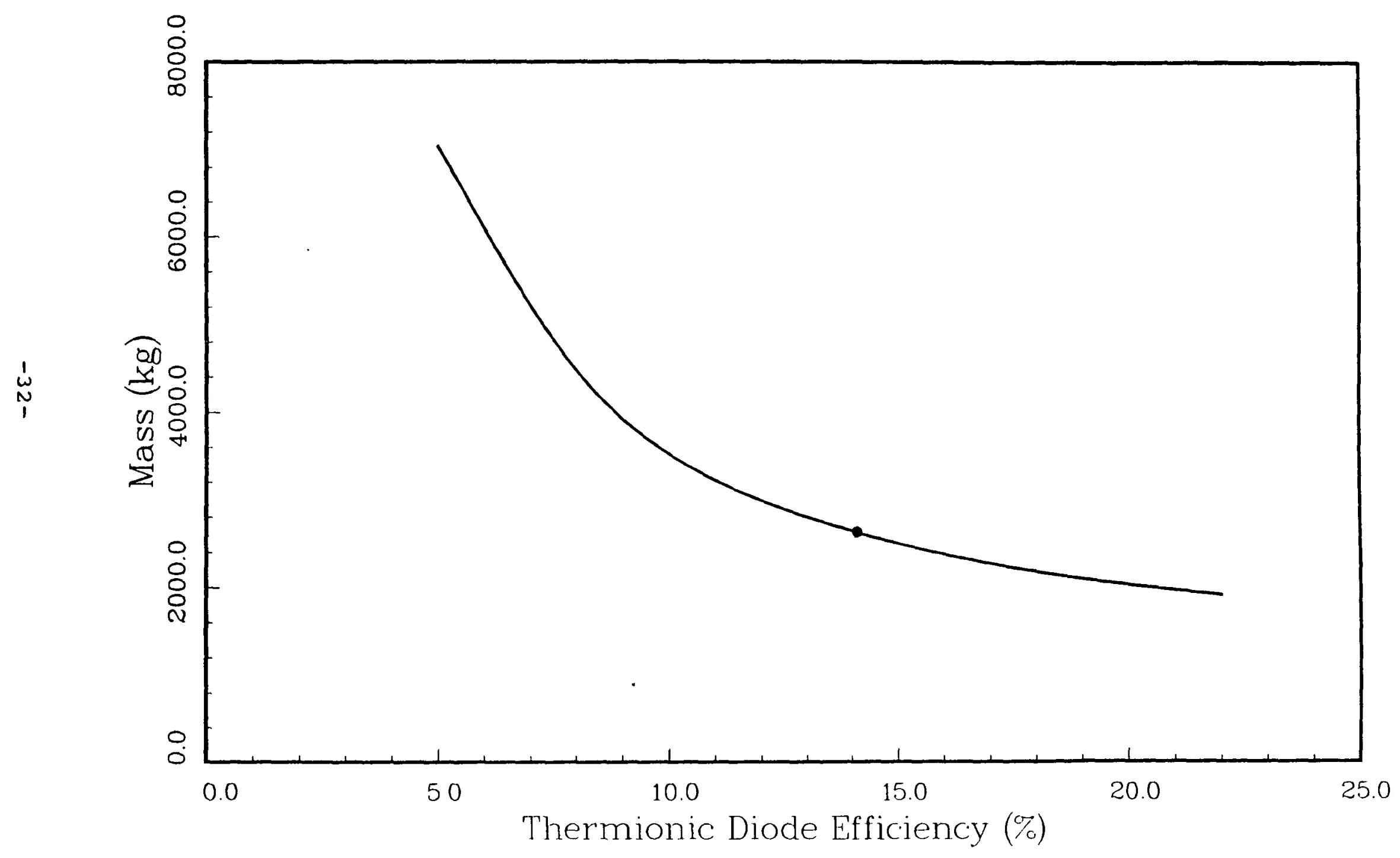


Figure 2.6

Impact of Core Surface Emissivity on the

Mass of a $20 \mathrm{kWe}$ STAR-C

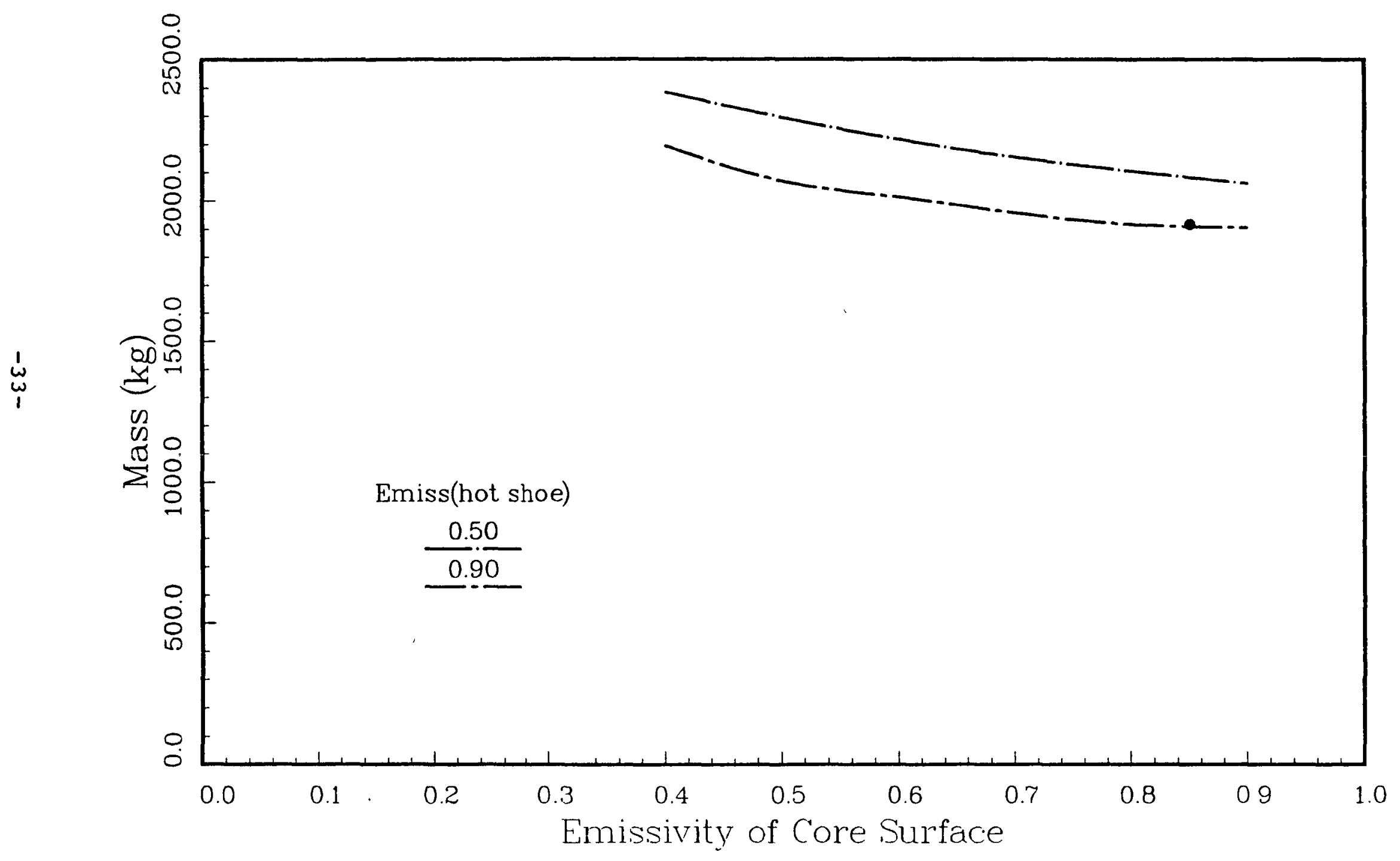


Figure 2.7

Impact of Core Surface Emissivity on the Mass of a 20 kWe STAR-C Using the Wrong Approach, i.e., $T_{\text {cs }}=2000 \mathrm{~K}$

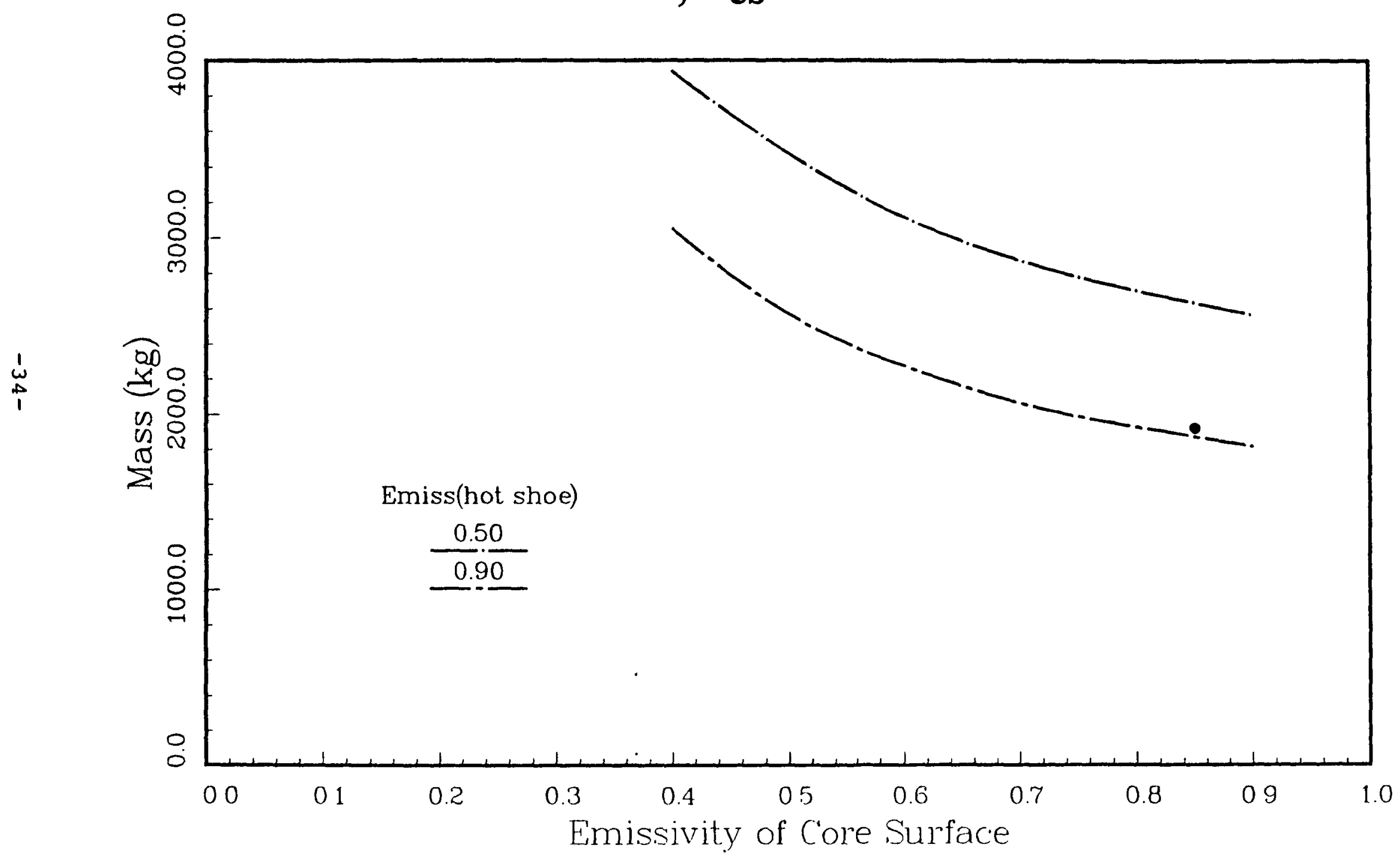


Figure 2.8

\section{Impact of Core Aspect Ratio on the Mass of a $10 \mathrm{kWe}$ STAR-C}

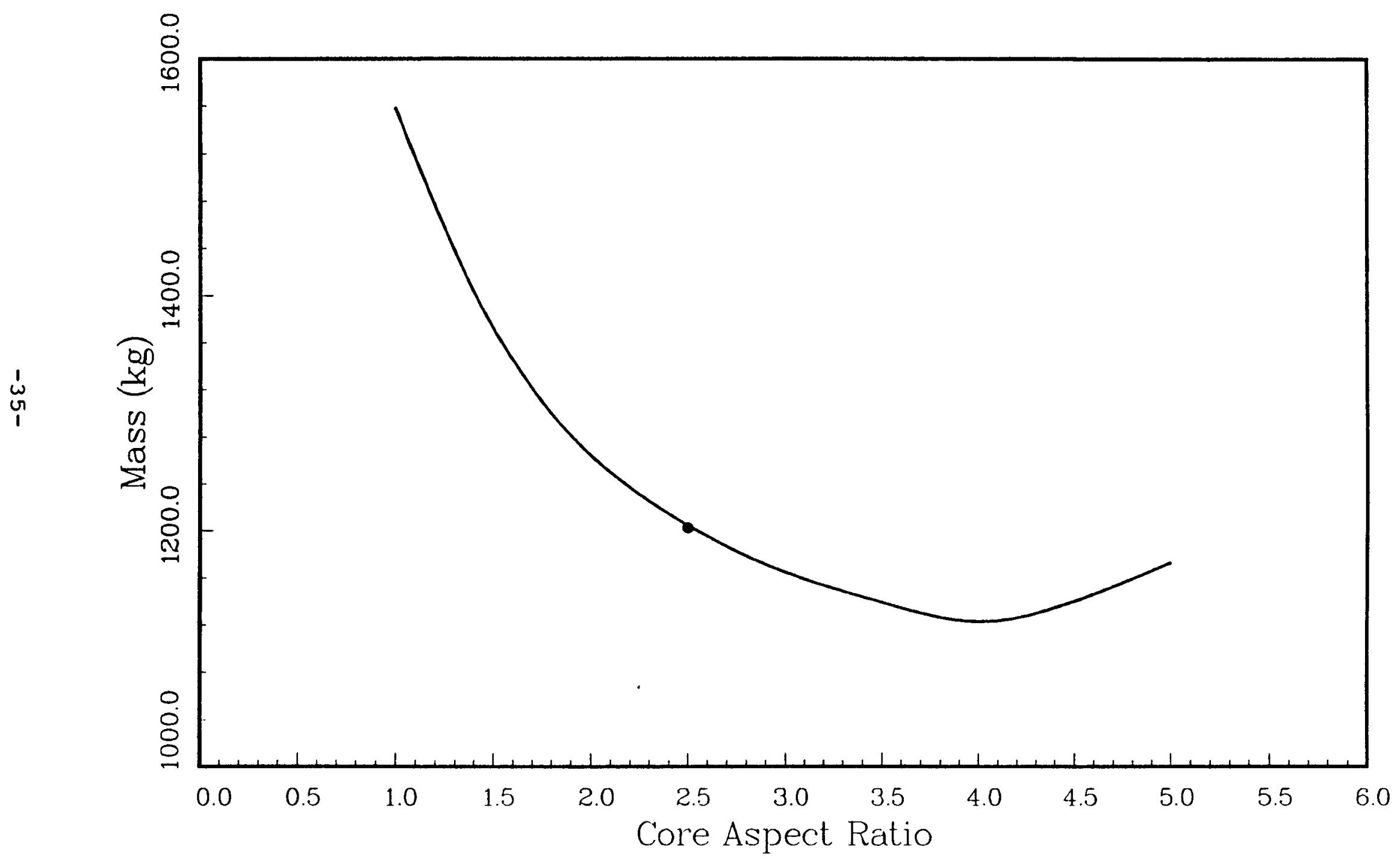


Figure 2.9

\section{Impact of Core Aspect Ratio on the} Mass of a $30 \mathrm{kWe}$ STAR-C

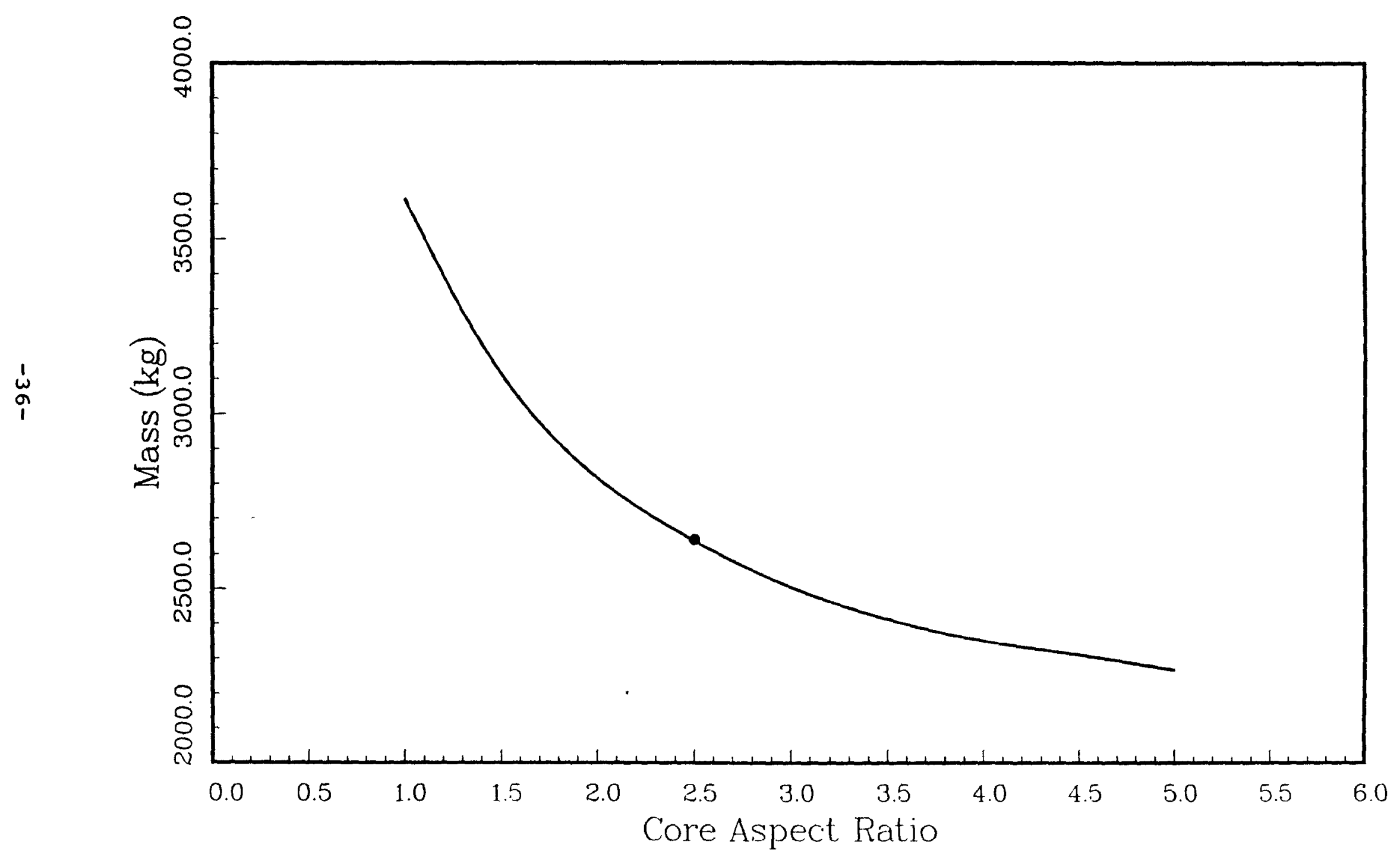


Figure 2.10

Comparison of Aspect Ratios

$4: 1$

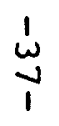

$2: 1$

$3: 1$

$2 \frac{1}{2}: 1$

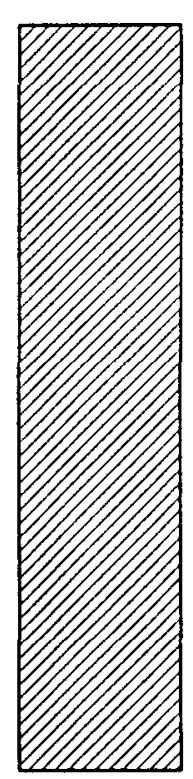




\subsection{Scalability of the OTR Power system}

The Sandia OTR system model was used to estimate the mass of a fully optimized OTR power system; one not restricted to a core thermal flux of $15.3 \mathrm{~W} / \mathrm{cm}^{2}$ as in Chapter 2 . As stated in Section 1.2, the two major differences between STAR-C and OTR are (1) the reactor core dimensions are allowed to vary to obtain a minimum mass, and (2) the thermionic converter used is based on data obtained from a ThermoElectron test converter [3]. The fully optimized OTR mass estimates are discussed in section 3.1. In section 3.2, the significance of the assumed parameter values for the base case OTR power systems discussed in section 3.1 is addressed. This is done by varying the parameter values over a wide range and

assessing the change in the power system mass estimate. The impact of system design changes is discussed in section 3.3 .

\subsection{Mass Estimates for OTR Power systems}

The Sandia OTR system model has been used to calculate the mass of a fully optimized OTR power system. The results of these calculations are given in Table 3.1 and plotted in Figure 3.1 as a function of power. Figure 3.1 also includes the Sandia mass estimates for the STAR-C power system for comparison. As this figure shows, optimization of an OTR power system with respect to mass can result in significant improvements over STAR-C as power levels increase. At $30 \mathrm{kWe}$, the STAR-C power system mass is $41 \%$ higher than the mass of the OTR power system.

It should be noted that the reactor core geometry, i.e., fuel tray dimensions, is optimized for each power level in Figure 3.1. This approach is appropriate since no OTR power system has been built. However, when the second OTR system is designed, the minimal cost approach may be to use the same core diameter as was used for the first power system. This could be the case when there is a small, i.e., <20\%, change in system power, and would result in a power system mass higher than that indicated in Figure 3.1 .

The primary reason that the system mass is improved by such a large amount at the higher power levels is that the thermal flux can be increased significantly with the proper core design. A second reason the mass decreases is that the use of the ThermoElectron TI converter increases system efficiency somewhat. Both of these factors reduce the required core surface area (Equation 2.1) and thus the power system mass. For the $30 \mathrm{kWe}$ OTR power system, the core thermal flux is $25 \mathrm{~W} / \mathrm{cm}^{2}$. The core thermal flux for the STAR-C is $15.3 \mathrm{~W} / \mathrm{cm}^{2}$. The TI converter efficiency for the OTR is $15.1 \%$, compared to $14.1 \%$ for STAR-C. 
The large increase in the core thermal flux that is obtained for the OTR power system results from improvements in the reactor core dimensions. Specifically, as the ratio of the inner to outer fuel radius increases, the temperature drop across the core decreases (Equation 2.3). Therefore, with a given maximum fuel temperature, the core surface temperature increases as the ratio of the inner to outer fuel radius increases. (Note: The derivative of Equation 2.3 with respect to the ratio of the fuel inner to outer radius, i.e., $r_{i} / r_{0}$, is positive, and so as $r_{i} / r_{0}$ increases the core surface temperature, $T_{C S}$, increases.) This higher core surface temperature results in a higher core thermal flux (Equation 2.2).

\subsection{Key System Parameters for OTRs}

There are several key system parameters that can have a significant impact on the mass of the OTR power system. Five of these parameters and their impact on the base case system masses are discussed below. The first four are parameters that impact system mass through their impact on core thermal flux and TI converter efficiency. The fifth parameter investigated is core aspect ratio.

\subsubsection{Emissivity of the core surface}

The emissivity of the core surface (and TI converter hot shoe) is important to the performance of an OTR, because it impacts the core thermal flux (Equation 2.2) and core thermal flux impacts the reactor core surface area (Equation 2.1). However, if the core surface temperature is calculated based on a maximum fuel temperature (Equation 2.3), then if the design value for emissivity is decreased, the core design can be changed as described in section 2.3.3 to keep the design output power constant. Figure 3.2 shows how the OTR system mass varies as a function of core surface emissivity for a $20 \mathrm{kWe}$ power system. This figure shows that a drop in the emissivities of the core surface and TI converter hot shoe do not have a large impact on system mass. If these

emissivities drop from 0.85 to 0.70 , the system mass increases by only $6 \%$.

\subsubsection{Maximum Fuel Temperature}

The maximum fuel temperature has a significant impact on the mass of a OTR power system as the power level increases (Figure 3.3). Maximum fuel temperature is important, because of its impact on the core surface temperature (Equation 2.3), which impacts the core thermal flux and core surface area (Equations 2.2 and 2.1). For a $30 \mathrm{kWe}$ OTR power system, the mass increases by $14 \%$ if the maximum fuel temperature drops from $2300 \mathrm{~K}$ to $2200 \mathrm{~K}$ and increases by $36 \%$ if it drops to $2100 \mathrm{~K}$. On the other hand, the system mass decreases by $11 \%$ if the maximum fuel temperature can be increased to $2400 \mathrm{~K}$. 


\subsubsection{TI Converter Emitter Temperature}

The temperature of the thermionic converter emitter, $\mathrm{T}_{e}$, can play an important role in the performance of an OTR power system, because it impacts both the converter efficiency (Figure 1.4) and the core thermal flux through its impact on the converter hot shoe temperature (Equation 2.2). (Note: $\mathrm{T}_{\mathrm{hs}}=\mathrm{T}_{\mathrm{e}}+\mathrm{k} \phi$ th, where $\mathrm{k}$ is a positive constant.) specifically, as the emitter temperature increases, the converter efficiency increases and the thermal flux decreases. These two effects tend to counter one another as can be seen in Equation 2.1 .

The impact of emitter temperature on the mass of a $20 \mathrm{kWe}$ OTR power system is presented in Figure 3.4. As can be seen, the consequence of decreasing the emitter temperature from its optimum of $2000 \mathrm{~K}$ to $1850 \mathrm{~K}$ is very minor--power system mass increases by only $1 \%$. Decreasing the emitter temperature to $1800 \mathrm{~K}$ increases system mass by $4 \%$.

\subsubsection{Thermal Conductivity of Graphite}

The thermal conductivity of graphite, $\mathrm{k}_{\mathrm{g}}$, is important in the design of an OTR, because it has an impact on the temperature of the core surface (Equation 2.3). Figure 3.5 shows the impact of the thermal conductivity on the mass of a $20 \mathrm{kWe}$ OTR power system. As is expected, as the thermal conductivity increases, the system mass decreases somewhat. Increasing the conductivity from 40 to $70 \mathrm{~W} / \mathrm{mK}$ reduces the system mass by $6 \%$.

\subsubsection{Core Aspect Ratio}

As was mentioned in section 2.3 .4 , the core aspect ratio is an important parameter in OTR design, because of its impact on the core mass required to obtain the necessary core surface area and on the size of the radiation shield. Figure 3.6 shows the impact of core aspect ratio on the mass of a $30 \mathrm{kWe}$ OTR power system. If the aspect ratio can be increased from 2.5 to 3.0 , the system mass decreases by $2 \%$. on the other hand, if the ratio drops to 2.0 , the mass increases by $4 \%$. These changes are smaller than the changes for a $30 \mathrm{kWe}$ STAR-C (Figure 2.10). This is because the OTR power system has been optimized and as a result there is less room for improvement.

\subsection{OTR Power System Design Changes}

Along with investigating the impact of key system parameters on OTR power system mass, the impacts of two system design changes have been investigated. These design changes are changing the fuel form to a particle fuel and (2) assuming that electronics that should be available in 1995 will be used in the payload. These design changes are discussed below. 


\subsubsection{Particle Fuel}

The fuel form used in all of the calculations so far has been monolithic blocks of $\mathrm{UC}_{2}$ in graphite trays (Figure 1.2). If the power system is required to retain all fission products, then it will be necessary to either design an elaborate system for capturing the gaseous and volatile fission products or to change to a fuel form that retains all fission products. For the purposes of this investigation, it was assumed that a triso-type fuel particle that would retain fission products could be manufactured. First order calculations were used to determine the dimensions of the particle; the $\mathrm{UC}_{2}$ fuel kernel has a radius of $200 \mu \mathrm{m}$, the porous graphite layer around the $\mathrm{UC}_{2}$ has a thickness of 50 $\mu \mathrm{m}$, and the ZrC coating over the graphite has a thickness of $25 \mu \mathrm{m}$. It was further assumed that the particles could be packed in graphite so as to comprise $55 \%$ of the fuel volume. The final assumptions made were that the thermal conductivity and maximum temperature of this fuel was the same as for the base case fuel. (Note: The particle fuel described here is purely hypothetical. Fuel testing would be required to determine if fission products could be retained for 10 years at the appropriate operating conditions. The above fuel description has been made so that illustrative calculations could be performed.)

Figure 3.7 shows the impact of changing from a monolithic fuel to a particle fuel. The mass of an OTR system with particle fuel is always greater under the assumptions made for this analysis. This can be explained as follows. As has been discussed previously, the mass of an OTR power system is minimized by making the ratio of the inner to outer fuel diameter a minimum. Since the $\mathrm{UC}_{2}$ fuel density is lower for our hypothetical particle fuel by about a factor of 2.0 , a larger ratio of inner to outer fuel diameter is required to achieve criticality. For example, for a $20 \mathrm{kWe}$ power system, this ratio changes from 0.60 to 0.51 when going from monolithic to particle fuel. Under the assumptions that the maximum fuel temperature and fuel thermal conductivity are the same for the two fuel types, this results in a lower core surface temperature for the particle fuel (Equation 2.3). This results in a lower thermal flux and larger core surface area (Equations 2.2 and 2.1).

Two factors must be considered before the conclusion can be reached that an OTR power system will always be more massive when particle fuel is used. First, it is possible that the maximum fuel temperature for particle fuel is higher than that of monolithic fuel. And second, the OTR system code does not include a mass for a fission product trapping system. It should be noted that a fission product trapping system may prevent the use of a central control rod if it were needed for safety purposes. Also, a fission product 
trapping system may preclude the use of a movable upper reflector as a safety feature.

\subsubsection{Advanced Rad-Hard Electronics}

Under the current political climate in the U.S., it is doubtful that a space nuclear power system will be required before about 2005. If this is the case, it is reasonable to assume that 1995 electronics will be used in the power system and payload. These electronics could be much harder to radiation than current electronics. The Weapons Laboratory currently has a program in place that should result in space qualified integrated circuits and memory chips that will have hardness values of 100 Mrad gamma and 1015 nvt neutrons $[7,8,9,10]$. This is substantially higher than the 0.5 Mrad and 1013 nvt used in this report. If a similar program were in place to develop power electronics that could withstand the higher radiation levels as well as single event burn-out, which can be induced by cosmic radiation, a substantial mass savings could be realized for space nuclear power systems. It should be noted, however, that the technical issues associated with hardening high voltage power electronics will be more difficult to solve than those associated with lower voltage integrated circuits and memory chips [10]. This is an area where a research program could have a high pay-off.

Figure 3.8 compares the masses of OTR power systems with current and advanced electronics for various power levels. significant mass savings are realized when the radiation hardness of the electronics increases by two orders of magnitude. At $10 \mathrm{kWe}$ the power system mass decreases by $26 \%$, and at $30 \mathrm{kWe}$ the power system mass decreases by $21 \%$. At the same time, the length of the separation boom decreases; for the $30 \mathrm{kWe}$ system the length drops from $20 \mathrm{~m}$ to $7 \mathrm{~m}$ with the increase in radiation hardness of the electronics. 
Table 3.1

Sandia Mass Estimates For An

Optimized OTR Power system

\begin{tabular}{rr} 
Power (kwe) & Mass (kg) \\
\hline 5 & 861 \\
6 & 909 \\
8 & 981 \\
10 & 1055 \\
15 & 1292 \\
20 & 1493 \\
30 & 1867 \\
40 & 2249 \\
50 & 2745
\end{tabular}




\section{Figure 3.1 \\ Scalability of the OTR and STAR-C Power Systems}

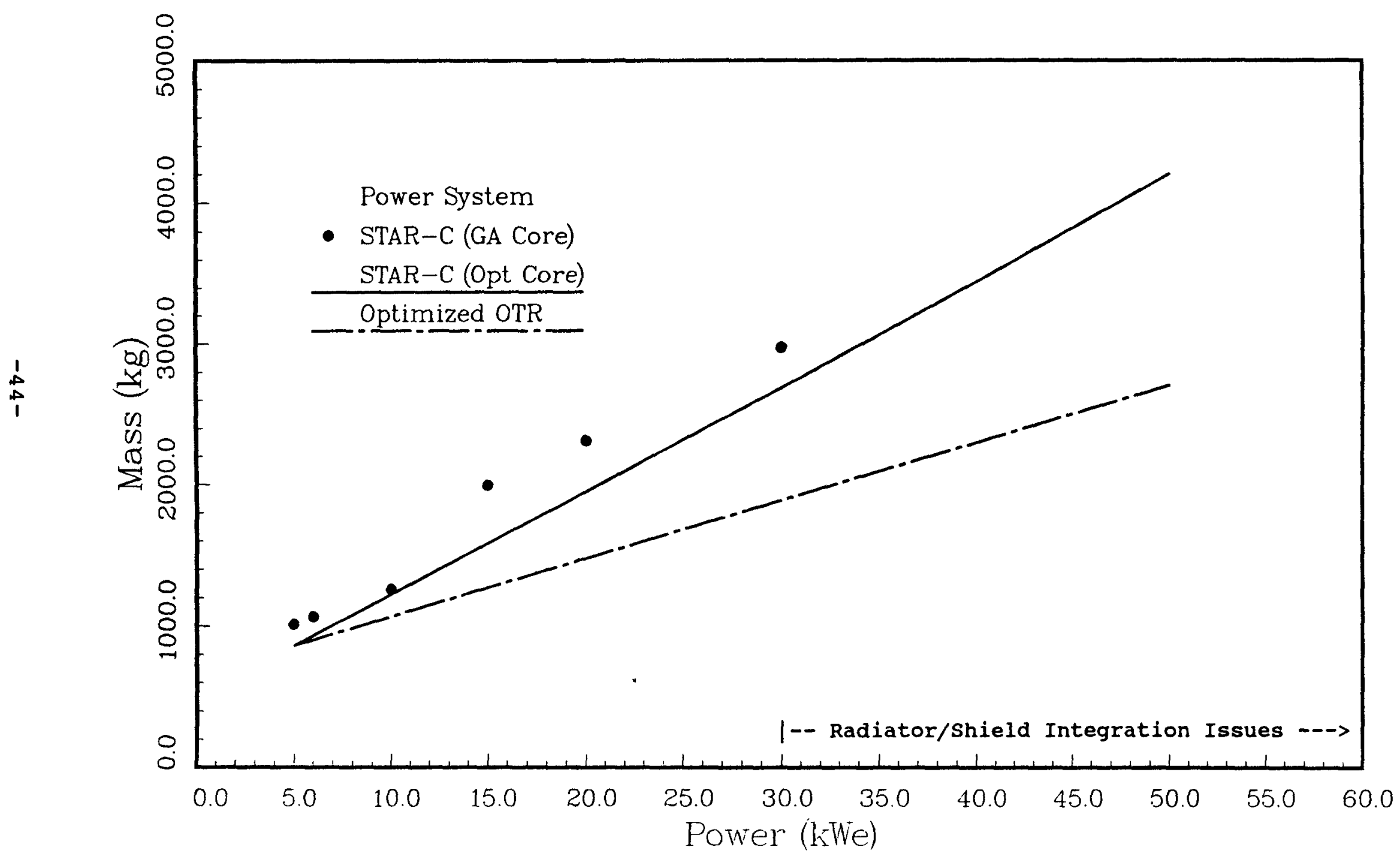


Figure 3.2

\section{Impact of Core Surface Emissivity on the Mass of a $20 \mathrm{kWe}$ OTR}

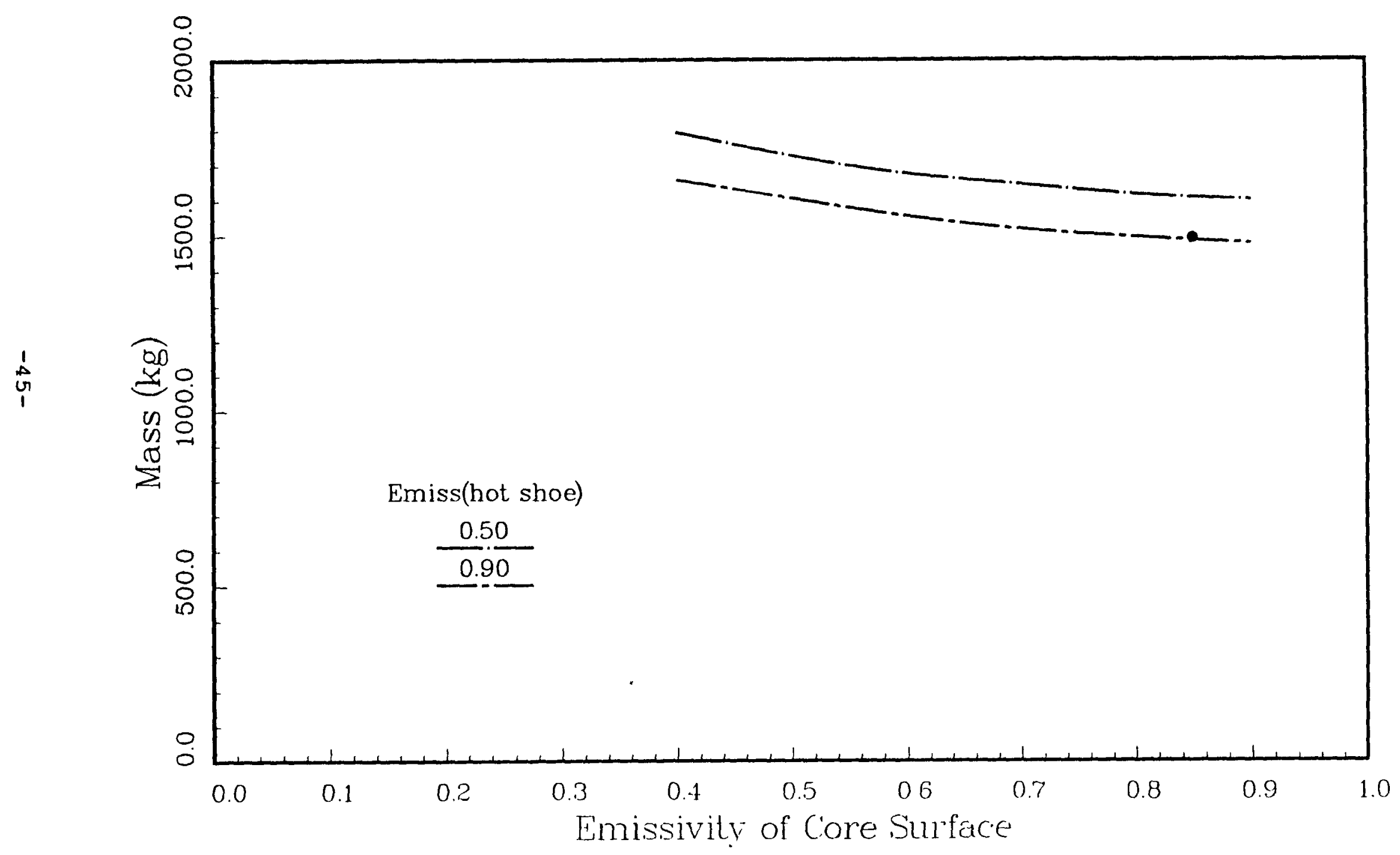




\section{Figure 3.3}

\section{Impact of Maximum Fuel Temperature on the Scalability of OTR Power Systems}

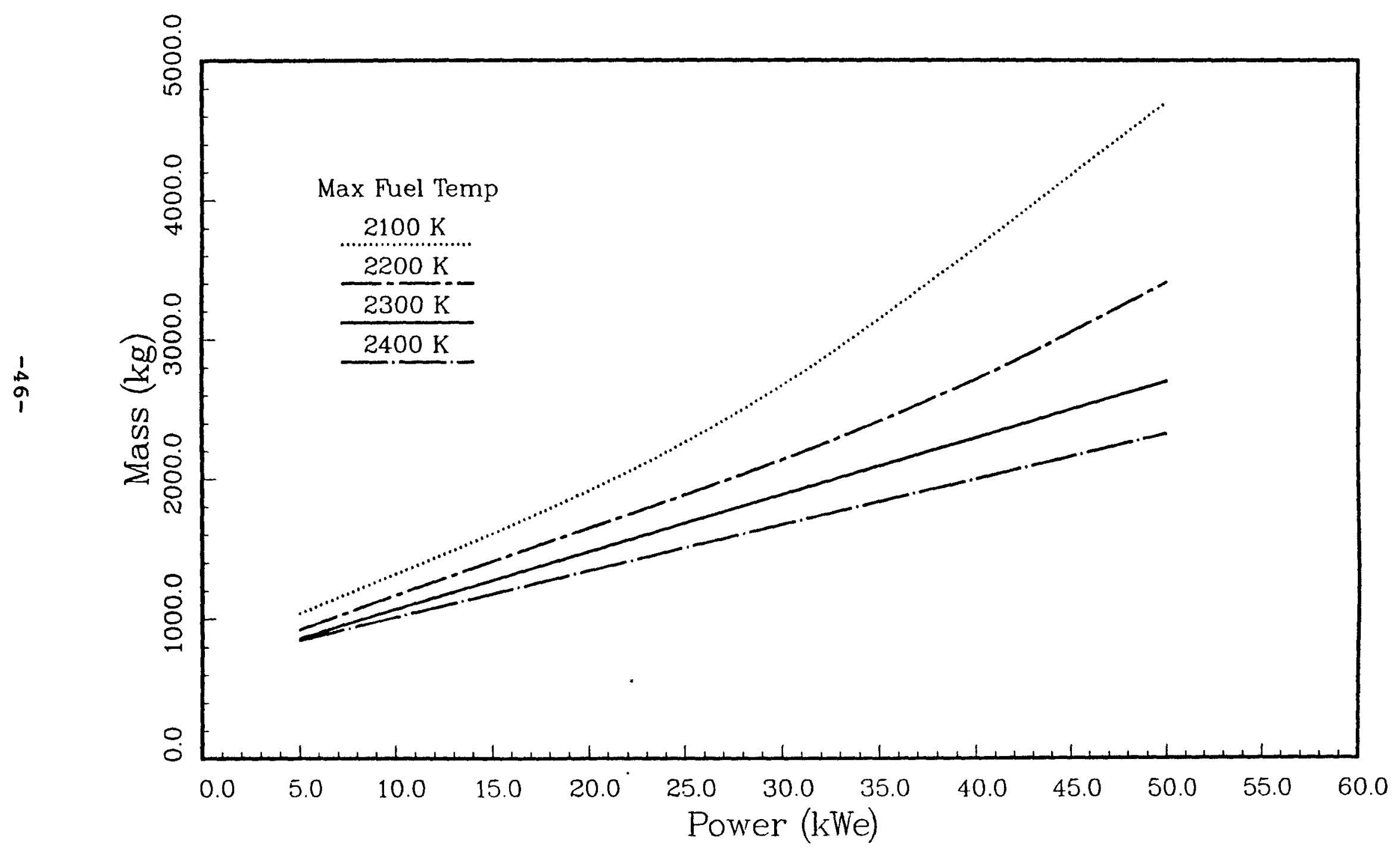


Figure 3.4

\section{Impact of TI Converter Emitter Temperature on the Mass of a $20 \mathrm{kWe}$ OTR}

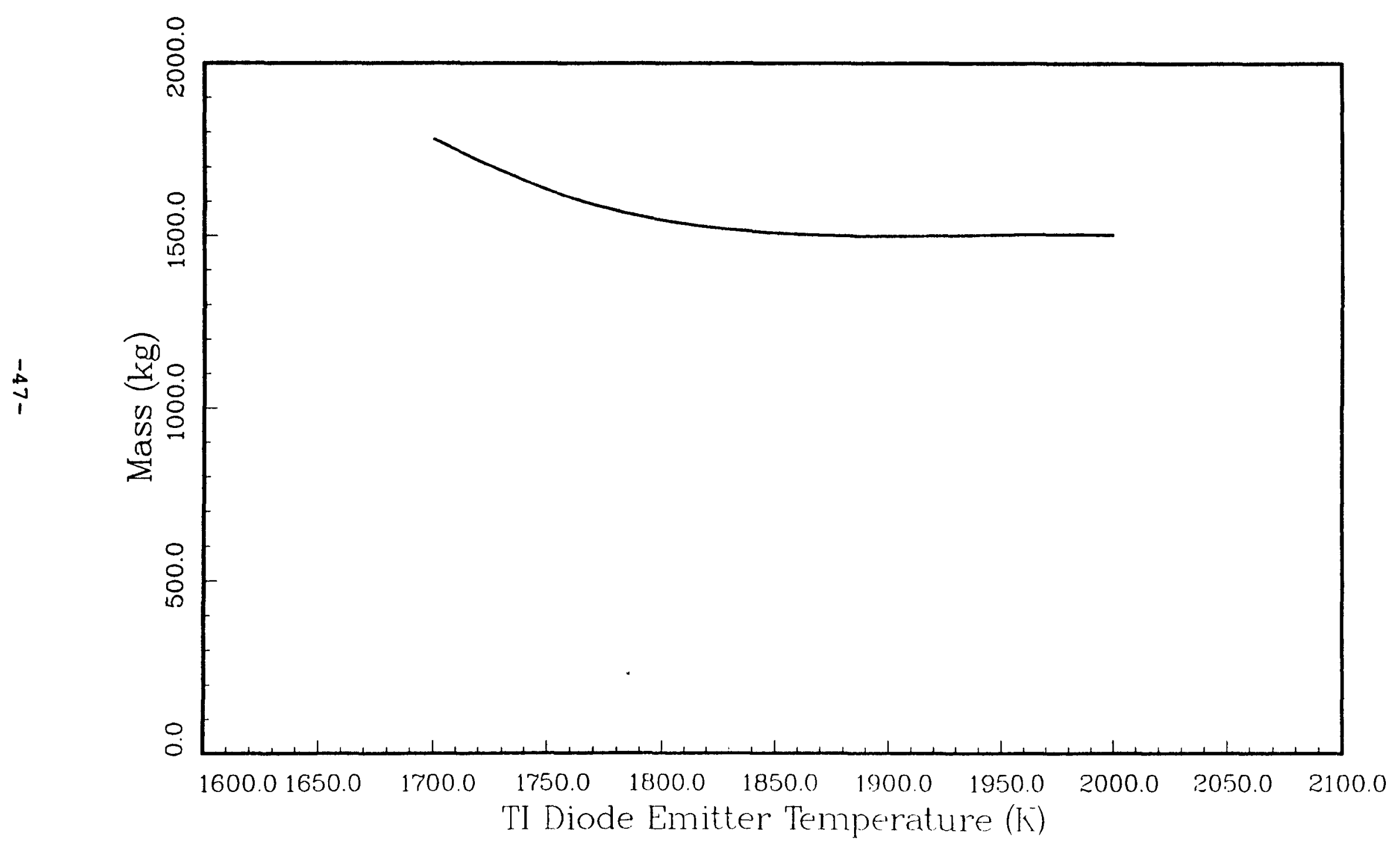




\section{Figure 3.5}

Impact of Graphite Thermal Conductivity on the Mass of a $20 \mathrm{kWe}$ OTR

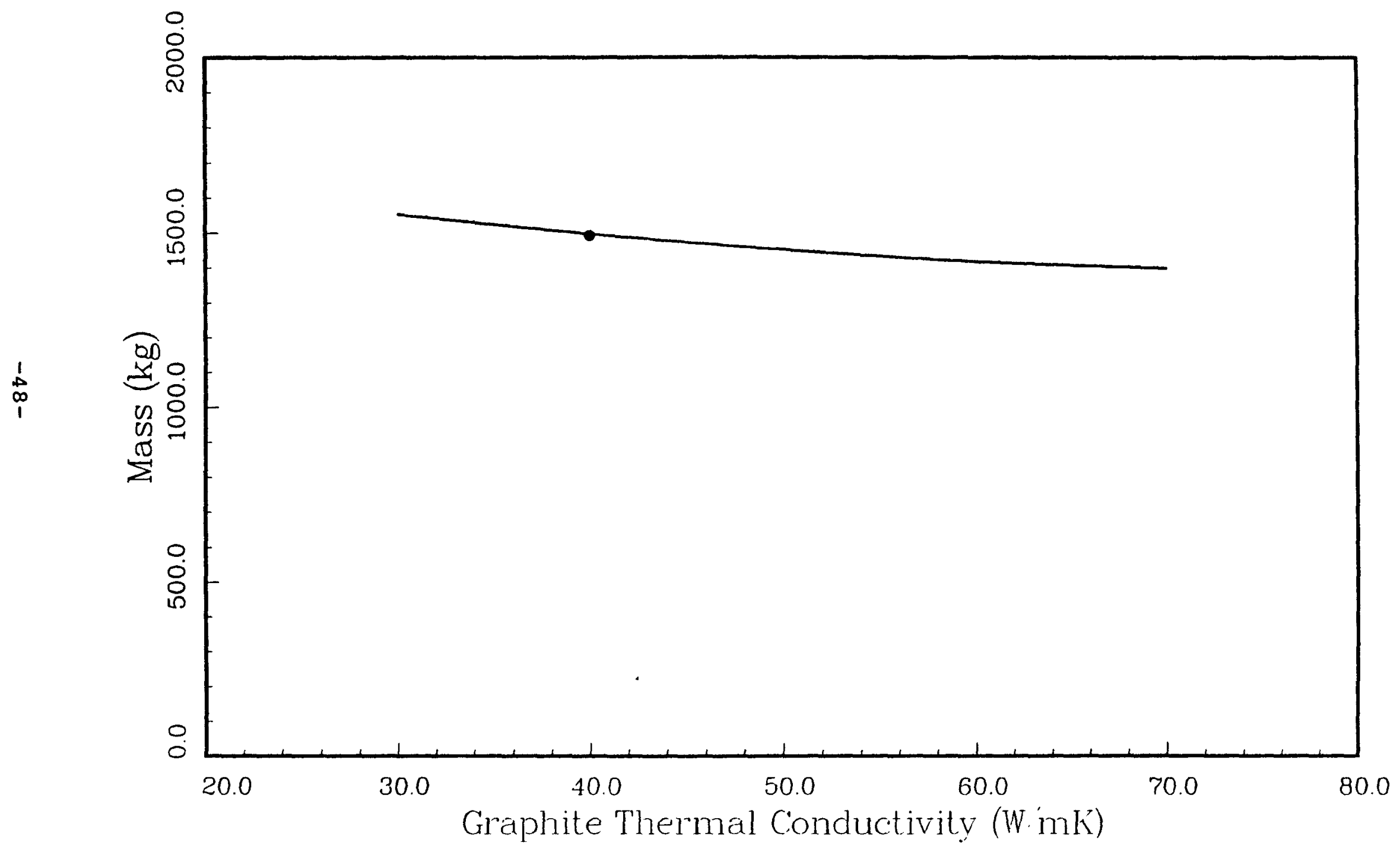


Figure 3.6

Impact of Core Aspect Ratio on the Mass of a $30 \mathrm{kWe}$ OTR

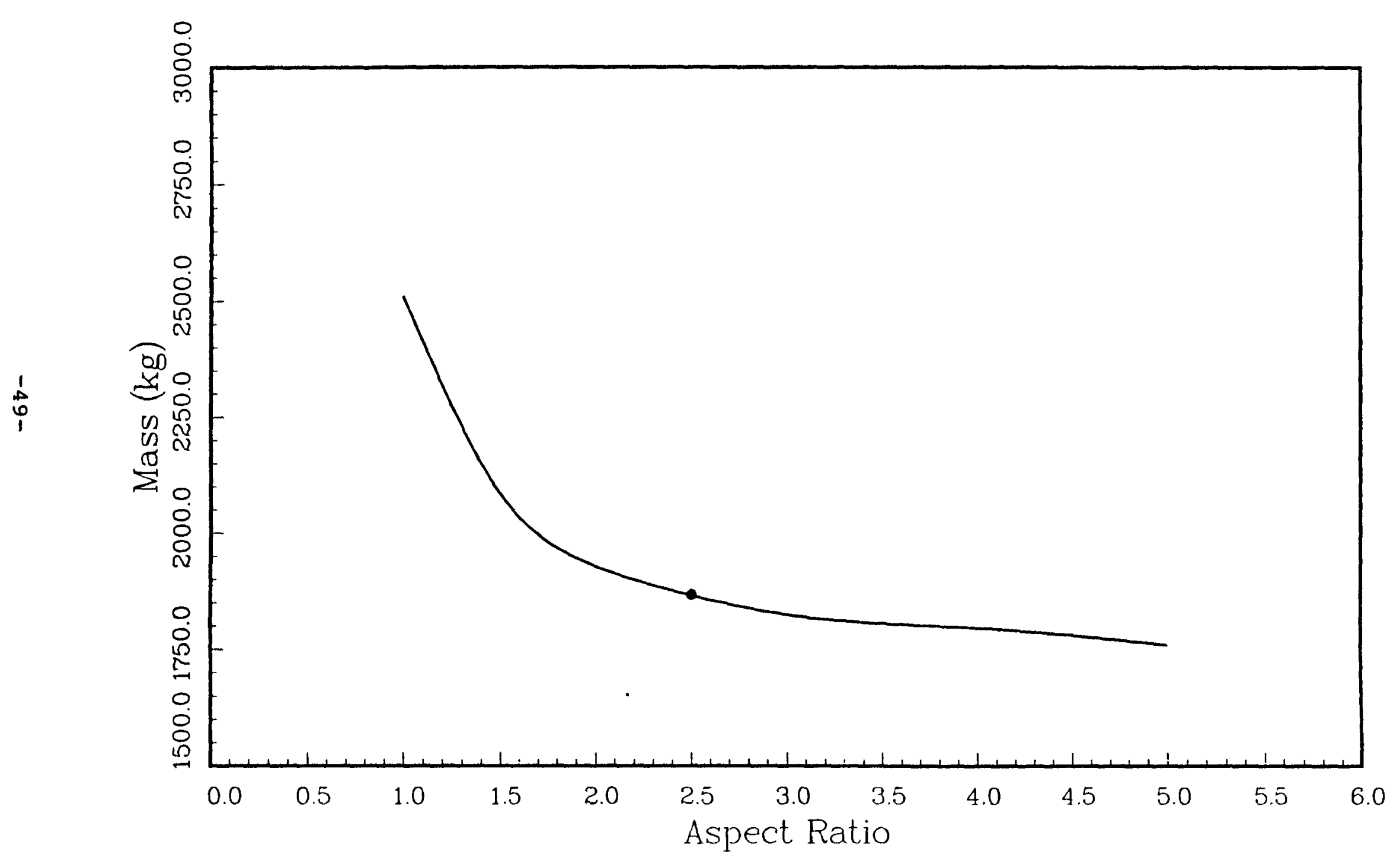


Figure 3.7

\section{Impact of a Particle Fuel on the Scalability of \\ Power Systems}

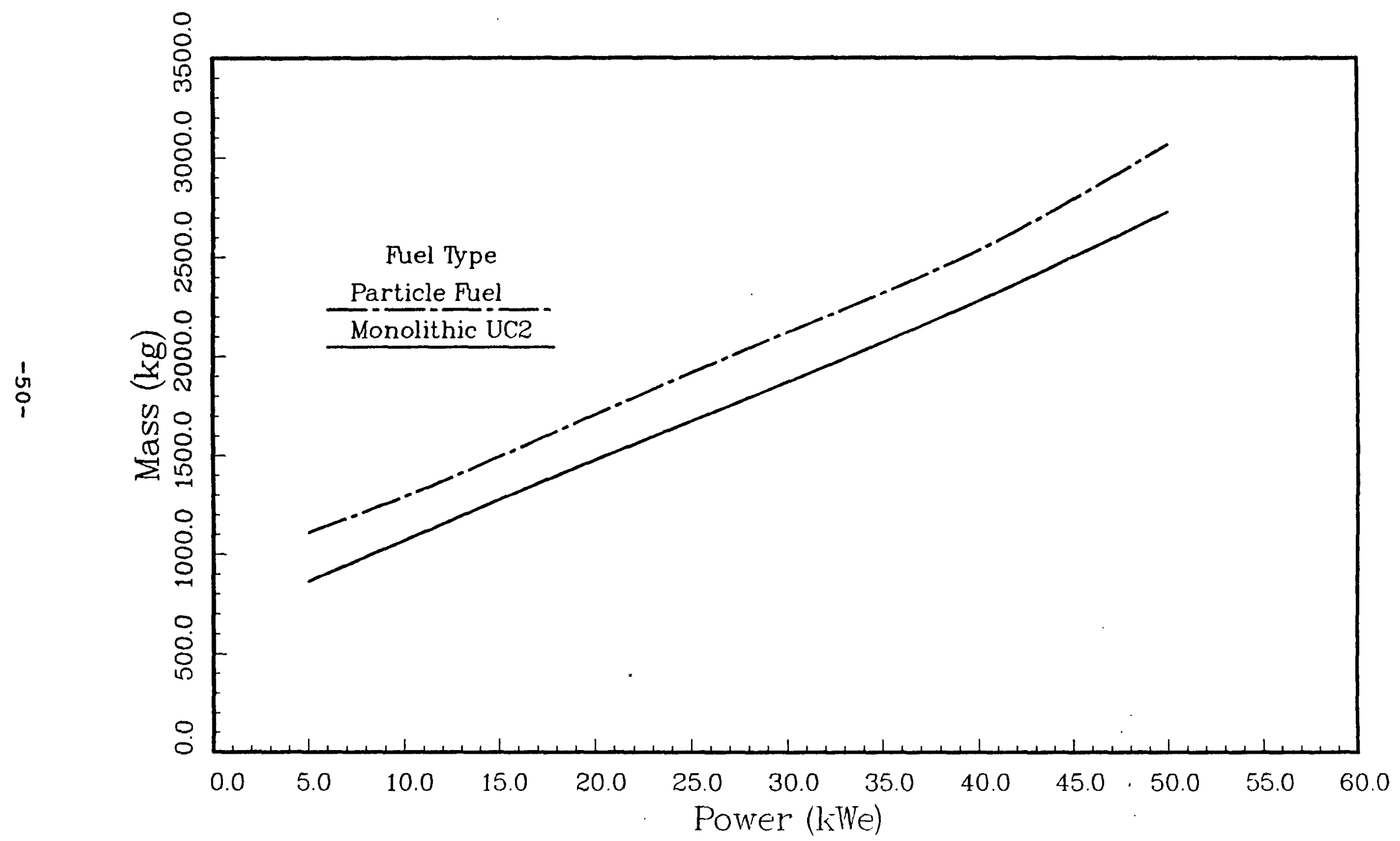




\section{Figure 3.8}

\section{Impact of Improved Rad-Hard Electronics on the Scalability of an OTR Power System}

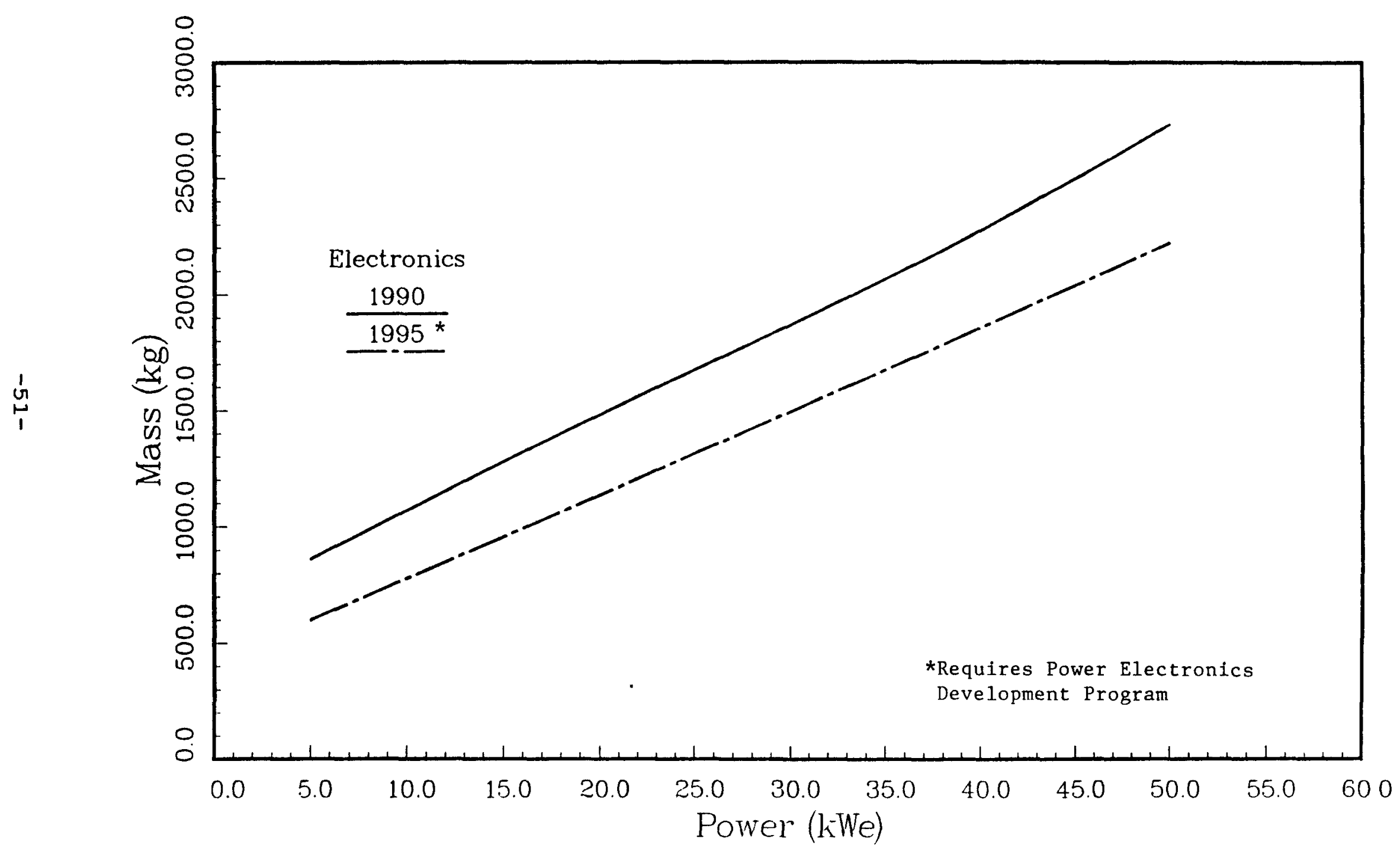




\subsection{Conclusions}

The objectives of this work were (1) to determine how well an OTR can scale with power level, (2) to determine the impact of key system parameters on OTR system performance, and (3) to compare the system performance of an optimized OTR power system with that of the STAR-C power system on a consistent basis.

The ability of an OTR power system to scale with power level is shown in Figure 4.1 [6]. This figure compares the scalability of STAR-C and OTR power systems with other nuclear power system options, e.g., the innovative SP-100, on a consistent basis. The mass estimates for the other power systems were obtained with power system codes developed at Sandia that are similar in nature to the OTR power system code. These codes will be documented in Reference 6 . Figure 4.1 shows that an optimized OTR power system is the least massive nuclear power system up to about $25 \mathrm{kWe}$ and that it is less massive than both the SP-100 and innovative SP-100 at all power levels up to $50 \mathrm{kWe,} \mathrm{which} \mathrm{is} \mathrm{about} \mathrm{as}$ large a power level as can be obtained with a single OTR. The one near-term power system that appears lighter than an OTR between 25 and $50 \mathrm{kWe}$ is the $\mathrm{SP}-100$ reactor with a Brayton conversion system. (Note: The SP-100/stirling system shown in Figure 4.1 assumes the use of refractory metals, which means that it, along with the sP-100/Rankine system, will not be available without several extra years of technology development. An SP-100/stirling system using superalloys would be a near-term system that might be lighter than an OTR in the 25 to 50 kWe power range.)

The system parameters that can have a significant impact on the scalability of an OTR power system are the aspect ratio of the core and those parameters that impact TI converter efficiency and core thermal flux. The aspect ratio is important because it impacts the core volume and the diameter of the radiation shield. TI converter efficiency and core thermal flux are important because they determine the required core surface area for power systems above about $8 \mathrm{kWe}$ (Equation 2.1). For the work performed here, it was assumed that the maximum core aspect ratio is 2.5 . If the aspect ratio must be reduced, the system mass increases. This effect is more pronounced as the power level increases. Paradoxically, the parameters such as emitter temperature that effect TI converter efficiency and core thermal flux have a smaller than expected effect on OTR power system mass. This is because a change in one parameter can be compensated for by changes in other parameters. 
Comparisons of an optimized OTR power system with the STAR-C power system are given in Figures 3.1 and 4.1 . These figures show that an optimized OTR scales better with power level than the STAR-C at all power levels, and this difference becomes significant at about $15 \mathrm{kWe}$. At $30 \mathrm{kWe}$, the STAR-C system mass is $41 \%$ higher than the OTR power system mass. A major consequence of the relatively poor STAR-C scalability is that it does not compare favorably with the innovative SP100 above $15 \mathrm{kWe}$. There are two major reasons that the STAR$C$ does not scale well with power level. First, GA chose to allow only two core diameters, 26 and $42 \mathrm{~cm}$, rather than optimizing the core diameter (and aspect ratio) for each power level. As a result, the reactor and shield masses are higher than they need to be. second, GA chose to set the inner to outer fuel diameter to 0.333 for all reactor designs rather than to maximize this ratio. As a result, the maximum core surface temperature for a STAR-C power system is about $2000 \mathrm{~K}$. This is based on a maximum fuel temperature of 2300 $K$. If the inner to outer fuel diameter ratio is maximized, the core surface temperature can be increased (Equation 2.3). (Many of the optimized OTR power systems had core surface temperatures of about $2100 \mathrm{~K}$.) This results in a higher thermal flux (Equation 2.2), which reduces the required core surface area (Equation 2.1). 


\section{Figure 4.1 \\ Comparison of the Scalability of OTR and STAR-C Power Systems With Other Space Nuclear Power Systems}

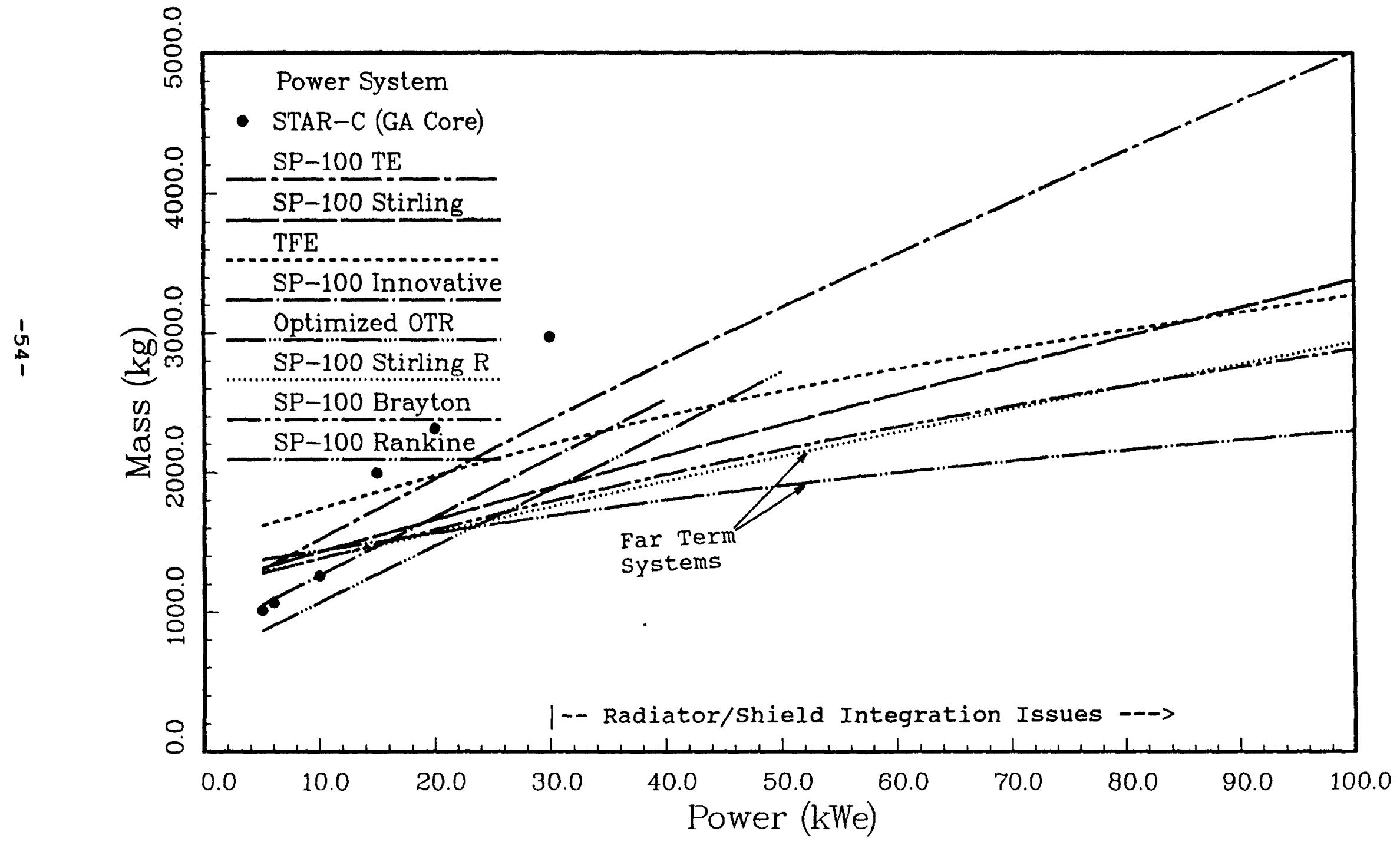




\section{REFERENCES}

1. Concept Definition Phase of The STAR-C Thermionic Power System For The Boost Surveillance And Tracking System, GA Technologies Report GA-C18676, January 1987.

2. STAR-C For LOW-Power Space Missions, GA Technologies, Viewgraph Presentation, October 19, 1987.

3. F. Rufeh and D. Lieb, The output Characteristics of A Vapor-Deposited Tungsten Emitter And A Molybdenym Collector, ThermoElectron Corp. Report, TE4086-3-70, June 1969 .

4. Albert Marshall, "Scaling Model For An Out-of-Core Thermionic Power system," Sandia National Laboratories, Memo to L. O. Cropp, February 13, 1989.

5. Albert Marshall, "Improvements To The STAR-C Model," Sandia National Laboratories, Memo to L. O. Cropp, February 24, 1989.

6. L. O. Cropp, et al., "Design Considerations For 10 to 1000 kwe Nuclear Reactor Power Systems For Space Applications," Sandia National Laboratories, to be published.

7. Air Force Space Technology Center, Presentation to the Air Force Nuclear Mission Advisory Board, November 8, 1989 .

8. Air Force Space Technology Center, Advanced Spaceborn Computer Module Program, Contract No. F29601-89-C-0084 with Honeywell.

9. Air Force Space Technology Center, Advanced Spaceborn Computer Module Program, Contract No. F29601-89-C-0089 with IBM.

10. William Dawes, Sandia National Laboratories, private communications, November 10, 1989. 


\section{Appendix A: Input parameters for the sandia OTR systems Model}


THE REQUiREd INPUT DATA For the REACTOR ARE:

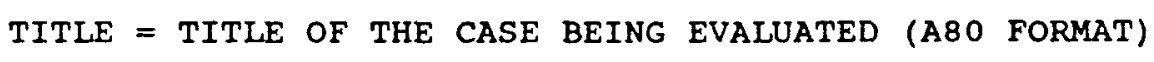




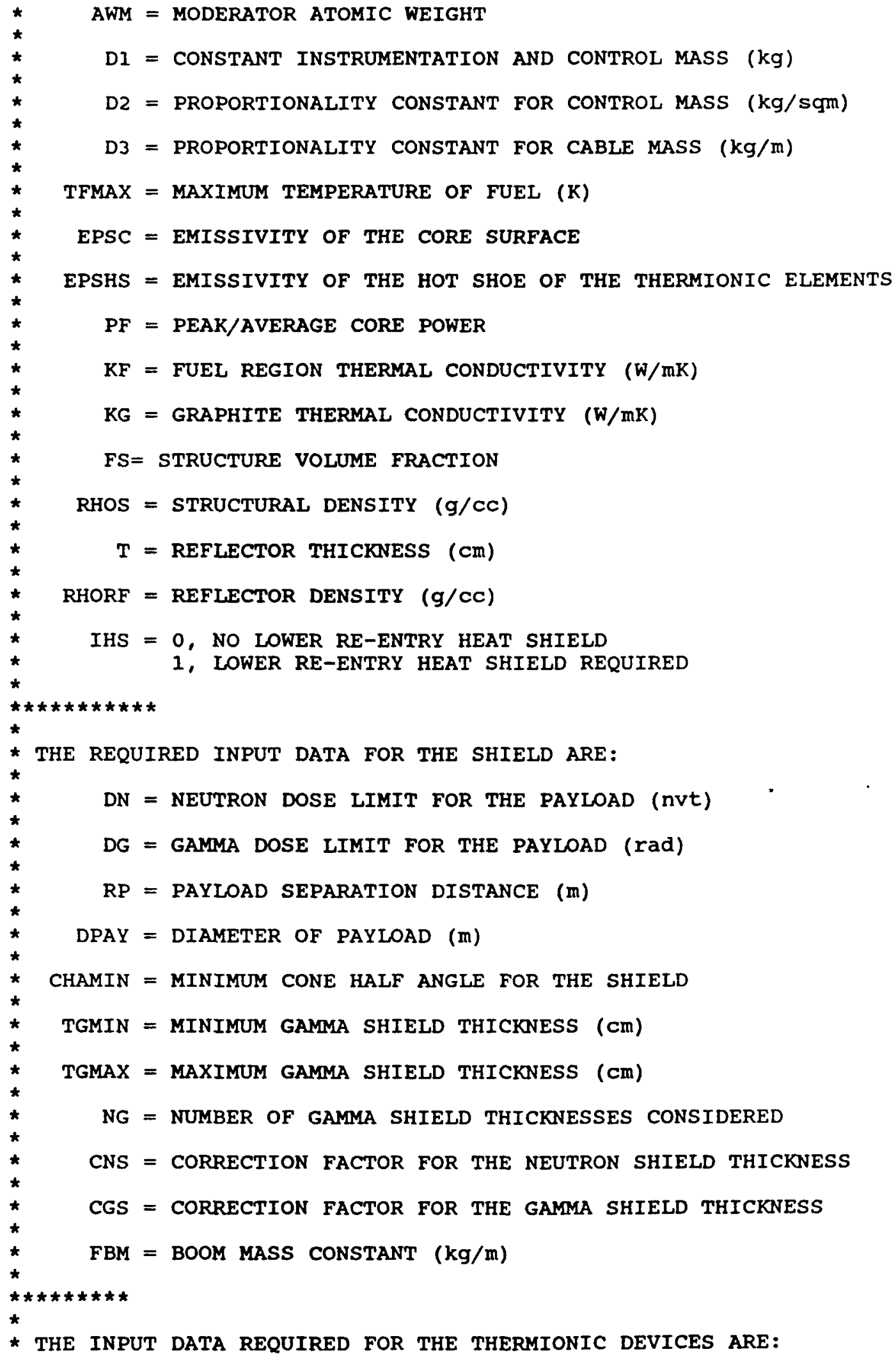




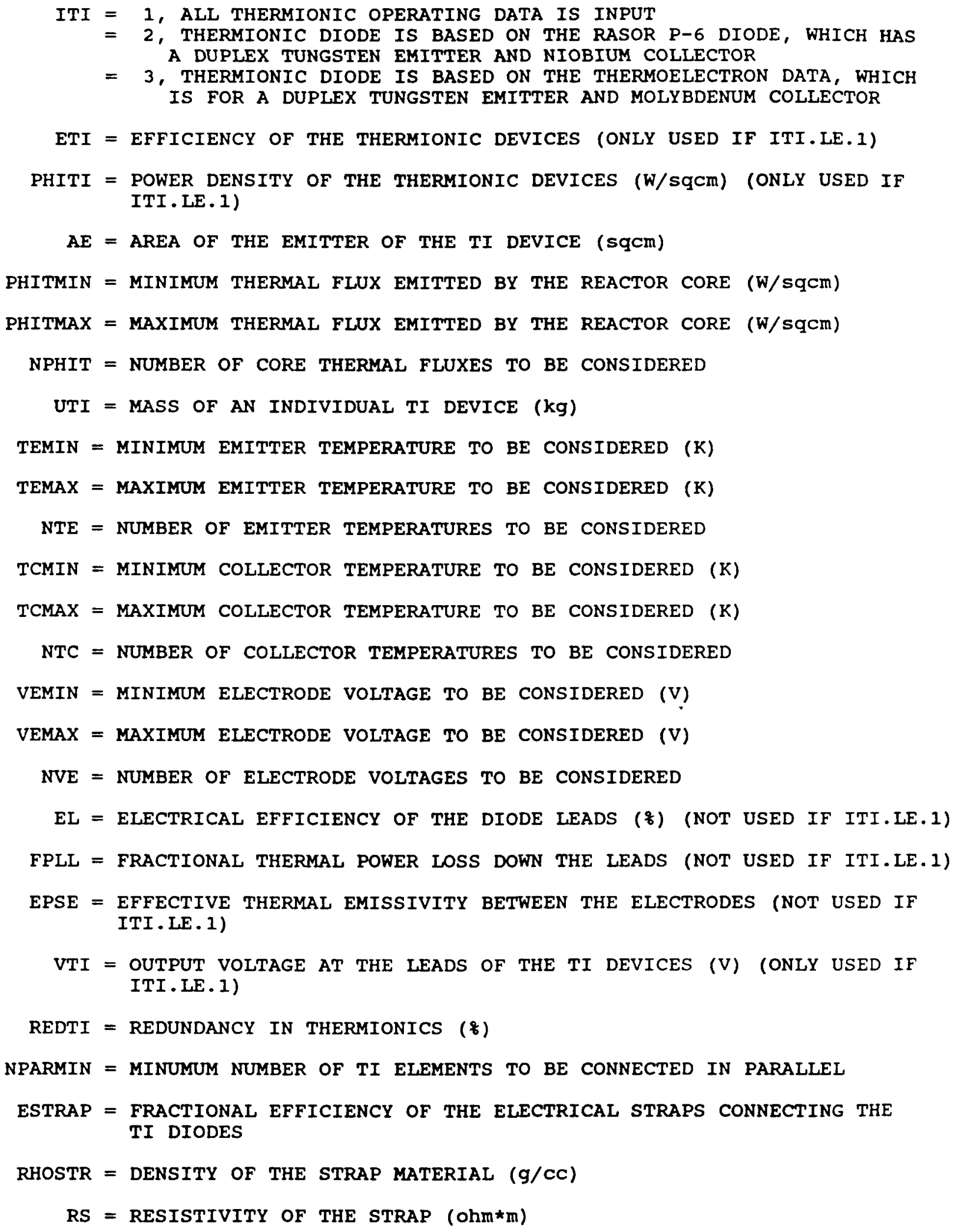




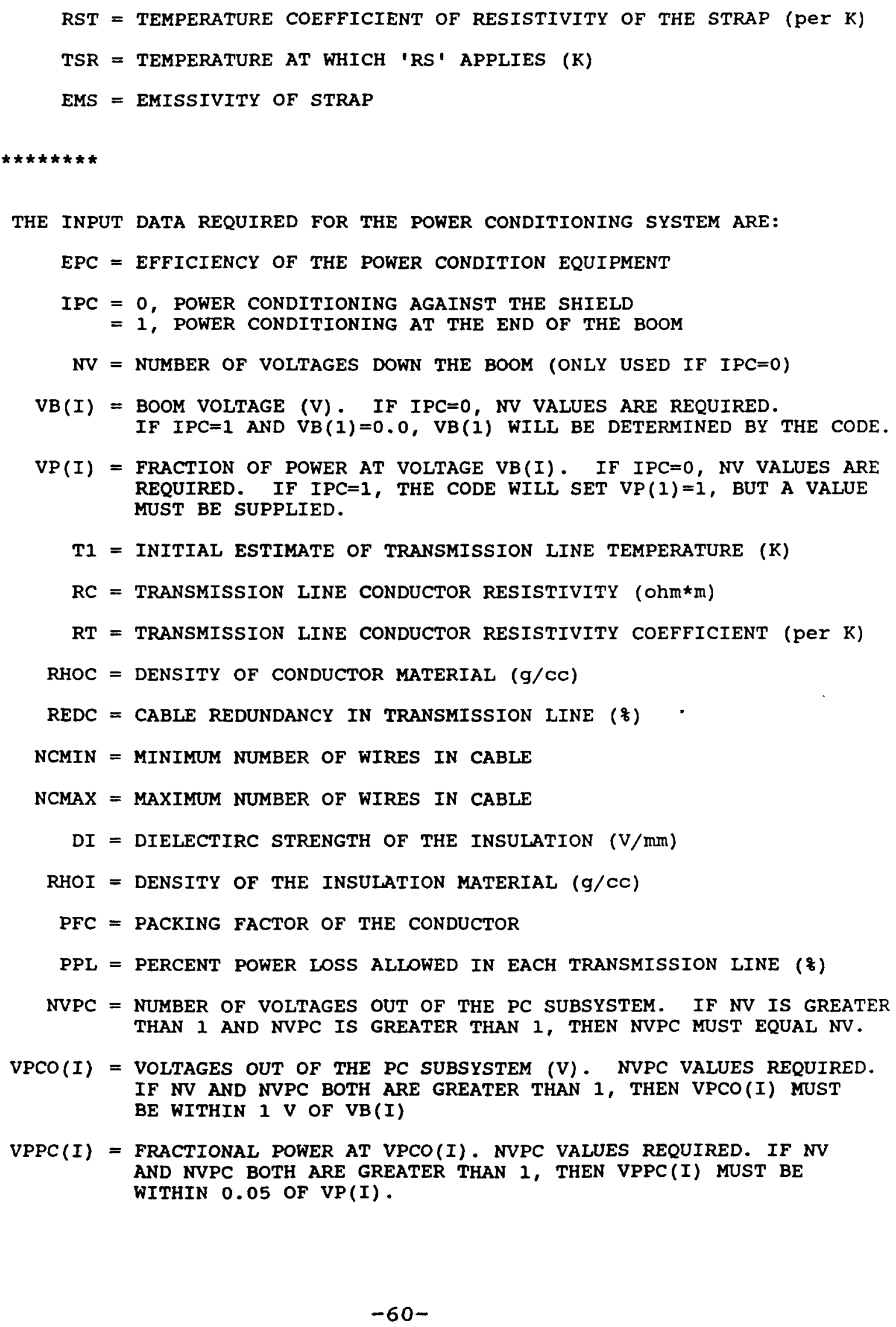


* MRLFLT = MASS OF RELAY AND FILTER WITHOUT CONVERTER (kg)

* MCTRL = MASS OF CONTROL ELECTRONICS (kg)

* $\quad$ SSWIT = SPECIFIC MASS OF POWER DISTRIBUTION SWITCH $(\mathrm{kg} / \mathrm{kW})$

* VMOD $=$ VOLUME OF PC ELECTRONICS MODULE $(\mathrm{cc} / \mathrm{kW})$

* UPCRAD = SPECIFIC MASS OF THE POWER CONDITIONING RADIATOR (kg/sqm)

* UPCSHLD = SPECIFIC MASS OF THE POWER CONDITIONING RADIATION SHIELD (g/sqCM)

* * REDPC $=$ REDUNDANCY IN POWER CONDITIONING $(\xi)$ 
Appendix B: Example Input for the Sandia OTR systems Model 


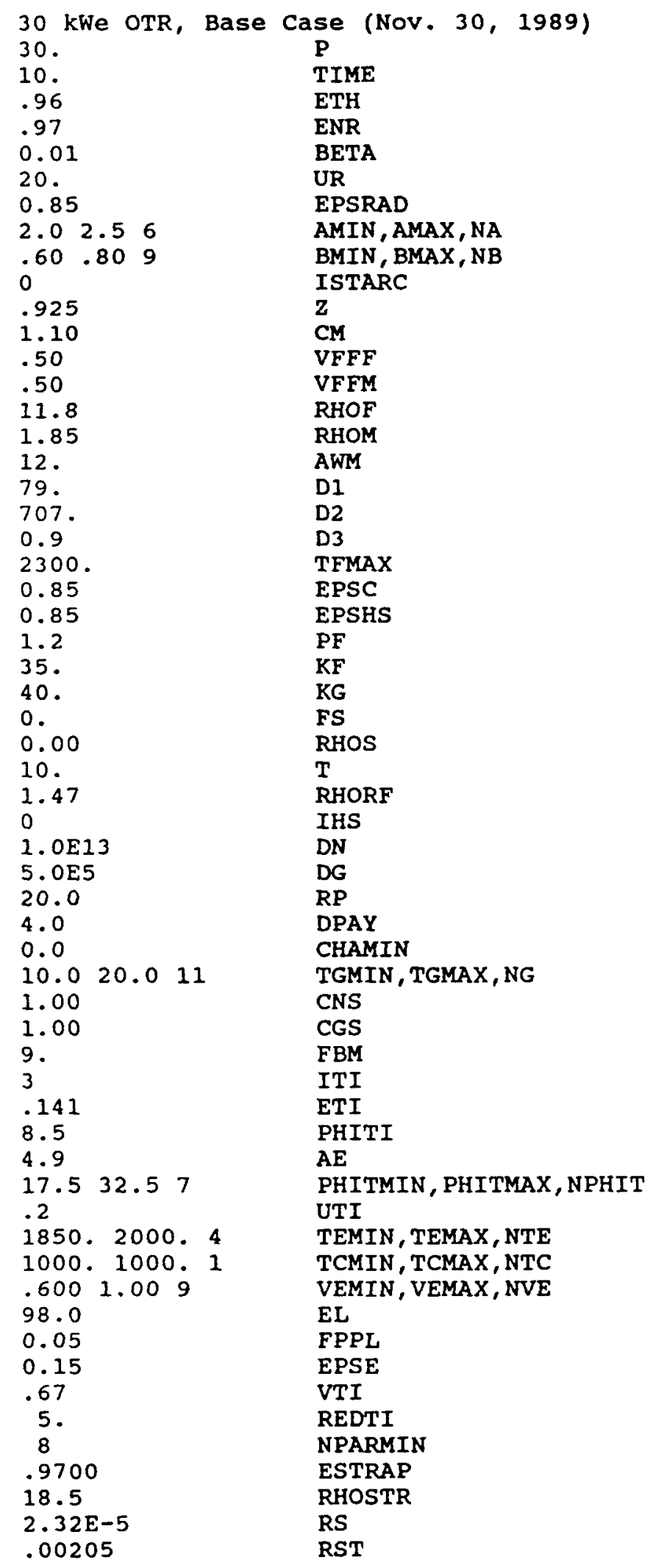




$\begin{array}{ll}900 . & \text { TSR } \\ .75 & \text { EMS } \\ 0.91 & \text { EPC } \\ 1 & \text { IPC } \\ 1 & \text { NV } \\ 00 . & \text { VB(.) } \\ 1.0 . & \text { VP(.) } \\ 300 . & \text { TI } \\ 2.65 E-8 & \text { RC } \\ 4.29 E-3 & \text { RT } \\ 2.7 & \text { RHOC } \\ 10.0 & \text { REDC } \\ 10 & \text { NCMIN } \\ 50 & \text { NCMAX } \\ 2000 . & \text { DI } \\ 2.5 & \text { RHOI } \\ 1.2 & \text { PFC } \\ 1.5 & \text { PPL } \\ 3 & \text { NVPC } \\ 5.28 .100 . & \text { VPCO (I) } \\ .15 .55 .30 & \text { VPPC(I) } \\ .09 & \text { MRLFLT } \\ .8 & \text { MCTRL } \\ .06 & \text { SSWIT } \\ 300 . & \text { VMOD } \\ 7.5 & \text { UPCRAD } \\ 4.0 & \text { UPCSHLD } \\ 10 . & \text { REDPC }\end{array}$


Appendix c: Example output from the Sandia OTR systems Model 
$30 \mathrm{kHe}$ OTR, Base Case (Nov. 30, 1989)

REACTOR INPUT DATA

$30.0 P$, POWER (KWE)

10.0 TIME, OPERATION TIME (YEARS)

0.960 ETH. THERMAL EFFICIEMCY OF THE POUER SYSTEM

0.970 ENR, FRACTIONAL ENRICHMENT

0.0100 BETÁ, FRACTIONAL BURNUP LIMIT

20.00 UR, MASS TO PONER RATIO FOR RADIATOR (KG/SOM)

0.85 EPSRAD, RADIATOR EMISSIVITY

2.00 AMIN, MIN LENGTH TO DIAMETER RATIO

2.50 AMAX, MAX LENGTH TO DIAMETER RATIO

6 NA, NUMBER OF L/O RATIOS

0.60 BMIN, MIN FUEL TO CORE DIAMETER RATIO

0.80 BMAX, MAX FUEL TO CORE DIAMETER RATIO

9 NB, NUMBER OF DIAMETER RATIOS

O ISTARC FLAG FOR CORE GEOMETRY (GA'S STAR-C)

0.932 ; FUEL TO CORE DIAMETER RATIO

$1.10 \mathrm{~cm}$, CRITICAL MASS CORRECTION FACTOR

0.500 VFFF, VOLUME FRACTION OF FUEL IN FUEL ANHULUS

0.500 VFFM, VOLUME FRACTION OF MOOERATOR IN FUEL ANHULUS

11.80 RHOF, FUEL DENSITY (G/CC)

1.85 RHOM, MOOERATOR DENSITY (G/CC)

12.0 ALM, MOOERATOR ATOMIC WEIGHT

79. D1, I\&C CONSTANT MASS (KG)

707. D2, PROP CONSTANT FOR CONTROL MASS (KG/SOM)

0.9003 , PROP CONSTANT FOR CABLE MASS (KG/M)

2300. TFMAX, MAX TEMPERATURE OF FUEL (K)

0.85 EPSC, EMISSIVITY OF CORE SURFACE

0.85 EPSHS, EMISSIVITY OF THERMIONIC ELEMENT HOT SHOE

$1.20 \mathrm{PF}$, PEAK/AVERAGE CORE POUER

35.0 KF, FUEL REGION THERMAL CONDUCTIVITY (W/M*K)

40.0 KG, GRAPHITE THERMAL CONDUCTIVITY (W/M*K)

0.000 FS, STRUCTURE VOLUME FRACTION

0.00 RHOS, STRUCTURE DENSITY (G/CC)

10.0 T, RÉFLECTOR THICKNESS (CM)

1.47 RHORF, REFLECTOR DENSITY (G/CC)

O IHS, FLAG FOR LOWER RE-ENTRY HEAT SHIELL

SHIELD INPUT DATA

1.00E+13 DN, NEUTRON DOSE LIMIT (NVT)

5. O0E+05 DG, GAMMA DOSE LIMIT (RAD)

20.0 RP: PAYLOAD SEPARATION DISTANCE (M)

4.00 DPAY, PAYLOAD OIAMETER (M)

0.0 CHAMIN. MINIMUM CONE HALF ANLGE FOR THE SHIELD (DEg)

10.00 TGMIN, MINIMUM GAMMA SHIELD THICKNESS (CM)

20.00 TGMAX, MAXIMUM GAMMA SHIELO THICKMESS (CM)

11 NG, NÚMBER OF GAMMA SHIELD THICKNESSES

1.00 CNS, NEUTRON SHIELD CORRECTION FACTOR

1.00 CGS, GAMMA SHIELD CORRECTION FACTOR

9.0 FBM, BOOM MASS CONSTANT (KG/M) 
THERMIONIC DEVICE INPUT DATA

3 ITI. FLAG FOR THERHIONIC DEVICE TYPE

0.141 ETI, THERMIONIC DEVICE EFFICIENCY

8.50 PHITI, II PONER DENSITY (H/SOCM)

4.90 AE, AREA OF THE TI EMITTER (SOCM)

17.50 PHITMIN, MINIMUM THERMAL FLUX FROM CORE (W/SOCM)

32.50 PHITMAX, MAXIMUM THERMAL FLUX FROM CORE (W/SOCM)

7 NPHIT, NUMBER OF CORE THERMAL FLUXES CONSIDERED

0.20 UTI. MASS OF A TI DEVICE (KG)

1850. TEMIN, MINIMUM EMITTER TEMPERATURE (K)

2000. TEMAX, MAXIMUM EMITTER TEMPERATURE (K)

4 NTE, NUMBER OF EMITTER TEMPERATURES CONSIDERED

1000. TCMIN, MINIMUM COLLECTOR TEMPERATURE (K)

1000. TCMAX, MAXIMU COLLECTOR TEMPERATURE (K)

I NTC NUMBER OF COLLECTOR TEMPERATURES CONSIDERED

0.60 VEMIN, MINIMUM ELECTROOE VOLTAGE (V)

1.00 VEMAX, MAXIMUM ELECTROOE VOLTAGE (V)

9 NVE, NUMBER OF ELECTROOE VOLTAGES

98.0 EL, TI LEAD EFFICIENCY ( $x$ )

0.050 FPLL, FRACTIONAL THERMAL PONER LOSS IN LEAD

0.150 EPSE, THERMAL EMISSIVITY IN INTERELECTROOE GAP

0.67 VTI II OUTPUT VOLTAGE (V)

5.0 REDTI REDUNDANCY IN THERMIONICS $(\boldsymbol{X})$

8 NPARMIN, MINIMUM PARALLEL CONHECTIONS OF TI DEVICES

0.97 ESTRAP.' EFFICIENCY OF ELECTRICAL STRAPS

18.50 RHOSTR, OENSITY OF STRAP MATERIAL (G/CC)

2.32E-05 RS, STRAP RESISTIVITY (OHM*M)

0.00205 RST, STRAP TEMPERATURE COEFF OF RESISTIVITY $(K-1)$

900. ISR, TEMPERATURE AT WHICH RS IS APPLICABLE (K)

0.75 EMS, STRAP EMISSIVITY

POWER CONDITIONING INPUT DATA

0.91 EPC, EFFICIENCY OF PONER CONDITIONING

1 IPC, LOCATION OF PONER CONOITIONING MOOULE

1 NV. NUMBER OF VOLTAGES DON BOOM

0.00 VB( 1$),$ BOOM VOLTAGE 1

1.000 VP(1); PERCENT POUER AT VB(1)

300. T1. ESTIMATED CABLE TEMPERATURE (K)

2.65E-08 RC, CONDUCTOR RESISTIVITY (OHM*M)

4.29E-03 RT, CONOUCTOR RESISTIVITY COEFFICIENT (K-1)

2.70 RHÓC, CONDUCTOR DENSITY (G/CC)

10.0 REDC, CABLE REDUNDANCY

10 NCMIN , MINIMUM NUMBER OF CABLES CONSIDERED

50 NCMAX, MAXIMUM NUMBER OF CABLES CONSIDERED

2000.00 DI, DIELECTRIC STRENGTH OF INSULATION

2.50 RHOI, DENSITY OF INSULATION MATERIAL $(G / C C)$

1.20 PFC, PACKING FRACTION OF CABLES

$1.50 \mathrm{PPL}$, PERCENT POWER LOSS ALLONED IN TRANSMISSION LINE

3 NVPC AUMBER OF VOLTAGES OUT OF PC

5.00 VPCO(1), PONER CONDITIONIMG VOLTAGE 1

0.15 VPPC (1), FRACTION OF POWER AT VPCO( 1 )

28.00 VPCO(2); PONER CONDITIOHING VOLTAGE 2

0.55 VPPC (2), FRACTION OF PONER AT VPCO (2)

100.00 VPCO (3); POWER CONDITIONING VOLTAGE 3

0.30 VPPC (3); FRACTION OF POUER AT VPCO( 3)

0.09 MRLFLT, MASS OF RELAY AND FILTER W/O CONVERTER (KG)

0.80 MCTRL, MASS OF PC CONTROL ELECTRONICS (KG)

0.060 SSWIT; SPECIFIC MASS OF POWER DIST SWITCH (KG/KW)

300. VMOO, SPECIFIC VOLUWE OF PC ELEC MOOULE (CC/KW)

7.50 UPCRAD, SPECIFIC MASS OF PC RADIATOR (KG/SOM)

4.00 UPCSHLD, SPECIFIC MASS OF PC RADIATION SHIELD (G/SCOM)

10.0 REDPC, REDUNDANCY IN PONER CONOITIONING (X) 
30 kHe OTR, Base Case (Nov. 30, 1989)

\begin{tabular}{|c|c|c|c|c|c|c|c|c|c|c|}
\hline $\begin{array}{l}\text { EMITTER } \\
\text { TEMP (K) }\end{array}$ & $\begin{array}{l}\text { COLLECTOR } \\
\text { TEMP (K) }\end{array}$ & $\begin{array}{l}\text { ELECTROOE } \\
\text { VOLT (V) }\end{array}$ & $\begin{array}{l}\text { POWER } \\
\text { (W/SOCM) }\end{array}$ & $\begin{array}{l}\text { LEAD } \\
\text { VOLT (V) }\end{array}$ & $\begin{array}{l}\text { THERMIONIC } \\
\text { EFF (X) }\end{array}$ & $\begin{array}{l}\text { SYSTEM } \\
\text { EFF (X) }\end{array}$ & $\begin{array}{l}\text { THERM FLUX } \\
\text { (H/SOCM) }\end{array}$ & $\begin{array}{l}\text { REACTOR } \\
\text { MASS (KG) }\end{array}$ & $\begin{array}{l}\text { SHIELD } \\
\text { MASS (KG) }\end{array}$ & $\begin{array}{c}\text { TOTAL } \\
\text { MASS (KG) }\end{array}$ \\
\hline 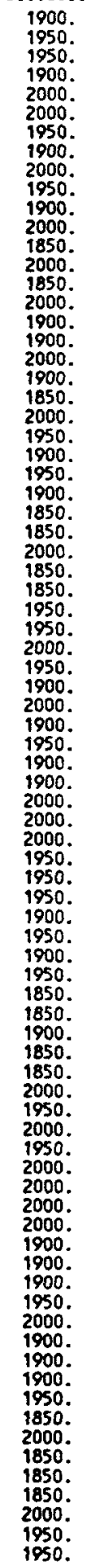 & 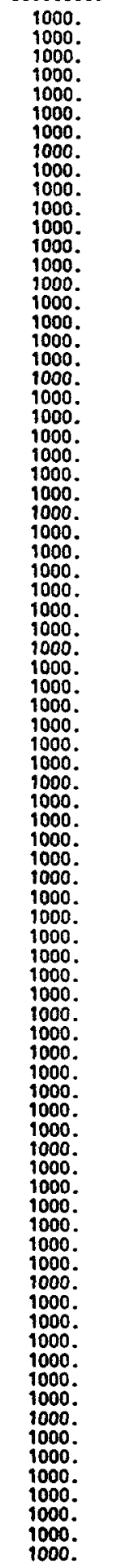 & 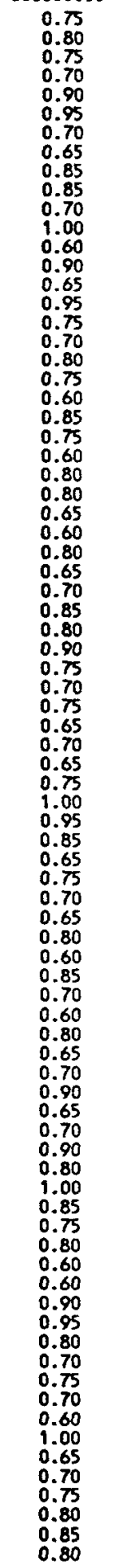 & 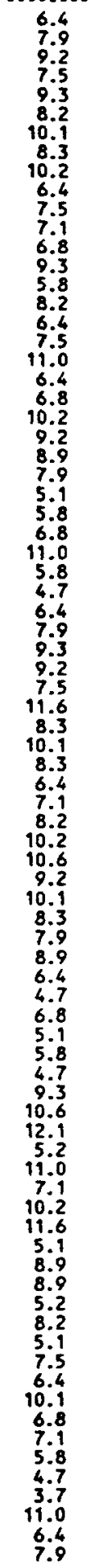 & 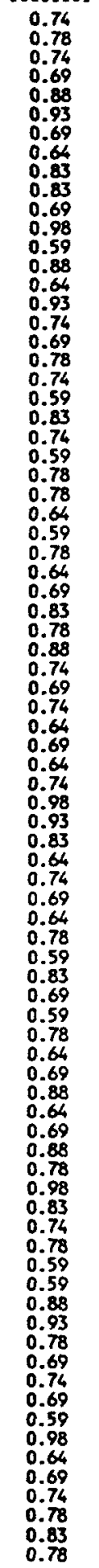 & 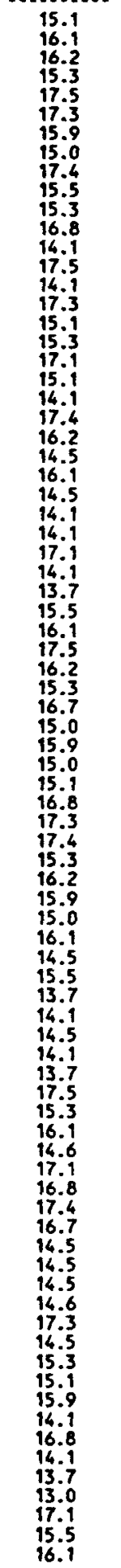 & 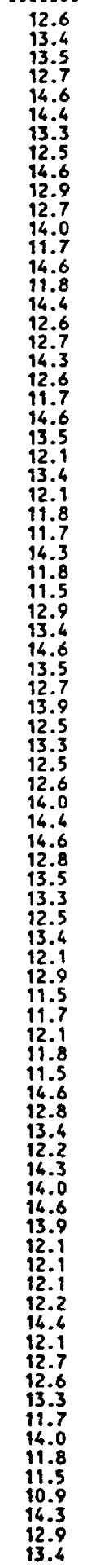 & 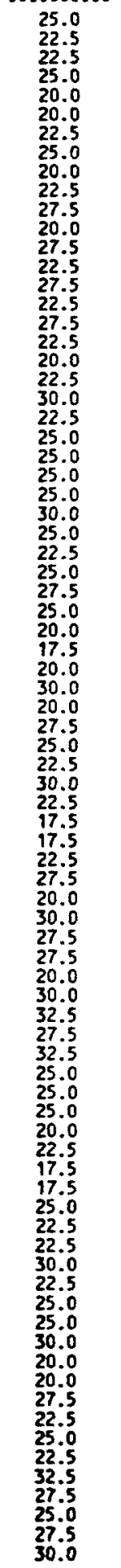 & 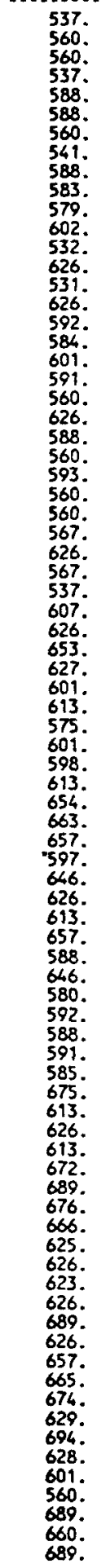 & 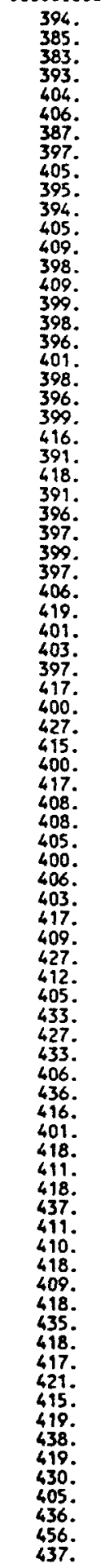 & 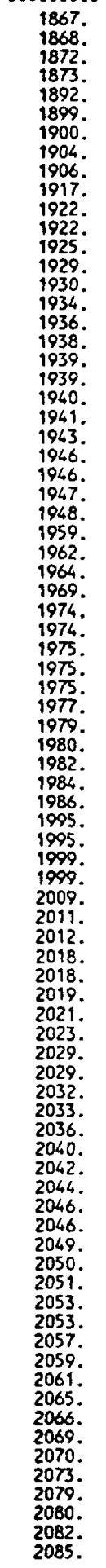 \\
\hline
\end{tabular}


30 kWe OTR, Base Case (Nov. 30, 1989)

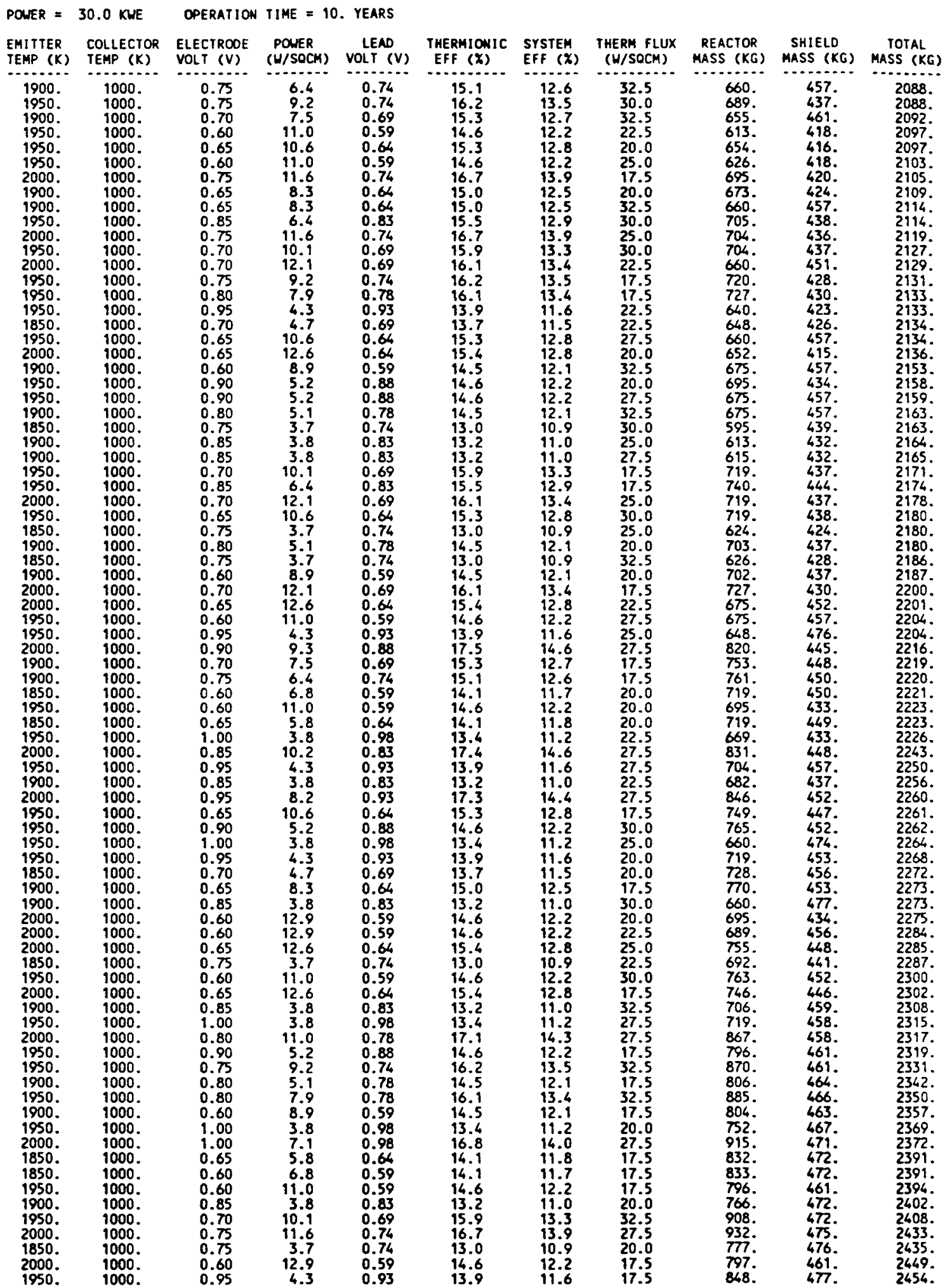


$30 \mathrm{kWe}$ OTR, Base Case (Nov. 30, 1989)

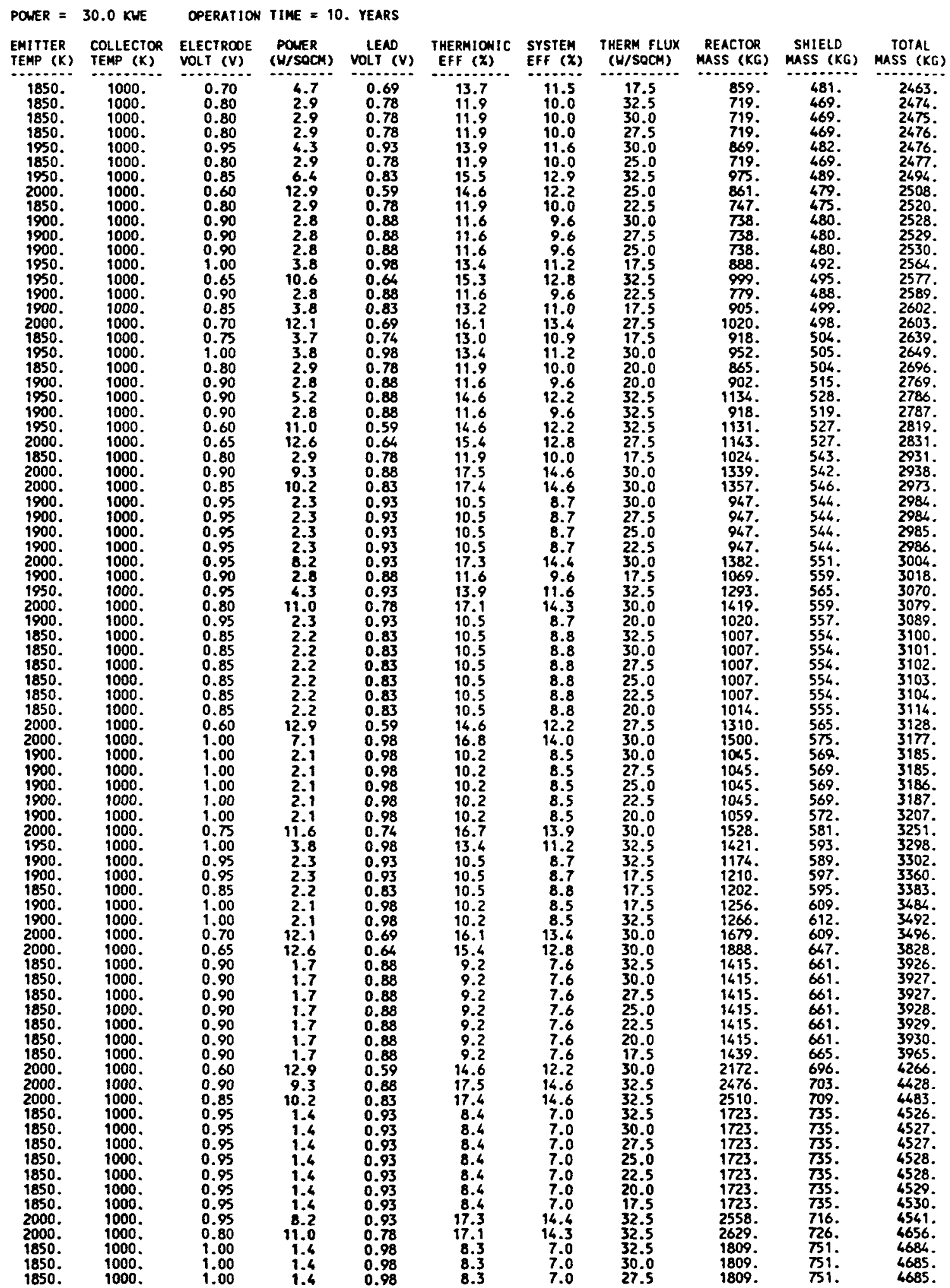


30 kHe OTR, Base Case (Nov. 30, 1989)

PONER $=30.0$ KWE OPERATION TIME $=10$. YEARS

\begin{tabular}{|c|c|c|c|c|c|c|c|c|c|c|}
\hline $\begin{array}{l}\text { EMITTER } \\
\text { TEMP (K) }\end{array}$ & $\begin{array}{l}\text { COLLECTOR } \\
\text { TEMP (K) }\end{array}$ & $\begin{array}{l}\text { ELECTROOE } \\
\text { VOLT (V) }\end{array}$ & $\begin{array}{l}\text { PONER } \\
\text { (W/SOCM) }\end{array}$ & $\begin{array}{l}\text { LEAD } \\
\text { VOLT }(V)\end{array}$ & $\begin{array}{l}\text { THERMIONIC } \\
\text { EFF }(X)\end{array}$ & $\begin{array}{l}\text { SYSTEM } \\
\text { EFF (X) }\end{array}$ & $\begin{array}{l}\text { THERM FLUX } \\
\text { (W/SOCM) }\end{array}$ & $\begin{array}{l}\text { REACTOR } \\
\text { MASS (KG) }\end{array}$ & $\begin{array}{l}\text { SHIELD } \\
\text { MASS (KG) }\end{array}$ & $\begin{array}{c}\text { TOTAL } \\
\text { MASS (KG) }\end{array}$ \\
\hline
\end{tabular}


30 kHe OTR, Base Case (Nov. 30, 1989)

THERMIONIC DATA

$\begin{array}{lr}\text { II DEVICE POWER } & 31 . \mathrm{u} \\ \text { II DEVICE VOLTAGE } & 0.73 \mathrm{v} \\ \text { II DEVICE EFF } & 15.1 \mathrm{x} \\ \text { EMITIER AREA } & 60.3 \mathrm{x} \\ \text { II NETWORK VOLTAGE } & 103.2 \mathrm{v} \\ \text { NUMBER OF DEVICES } & 1179 \\ \text { MASS OF DEVICES } & 236 . \mathrm{KG}\end{array}$

STRAP DATA

$\begin{array}{ll}\text { EFFICIENCY } & 97.0 \mathrm{~K} \\ \text { MASS } & 27 . \mathrm{KG} \\ \text { DIAMETER } & 0.52 \mathrm{CM} \\ \text { LENGTH } & 67.93 \mathrm{M} \\ \text { TEMPERATURE } & 1005 . \mathrm{K}\end{array}$

PONER CONOITIONING DATA

$\begin{array}{lc}\text { EFFICIENCY } & 91.0 \times \\ \text { VOLUME } & 0.002 \mathrm{M} * 3 \\ \text { MASS } & 39 . \mathrm{KG} \\ \text { SHIELO MASS } & 3 . \mathrm{KG} \\ \text { RADIATOR MASS } & 17 . \mathrm{KG} \\ \text { RADIATOR AREA } & 2.22 \mathrm{M} * 2\end{array}$

EFFICIENCY SUMMARY

$\begin{array}{ll}\text { THERMIONICS } & 15.1 \% \\ \text { STRAP } & 97.0 \% \\ \text { TRANSMISSION LINE } & 98.4 \% \\ \text { POWER CONDITIONING } & 91.0 \% \\ \text { NET ELECTRICAL } & 13.1 \%\end{array}$


30 kWe OTR, Base Case (Nov. 30, 1989)

POWER $=34.5 \mathrm{~kW}$

VOLTAGE $=100.0 \mathrm{~V}$

HIRE GUAGE $=7$

TRANSMISSION LINE TABLE (NO REDUNOANCY)

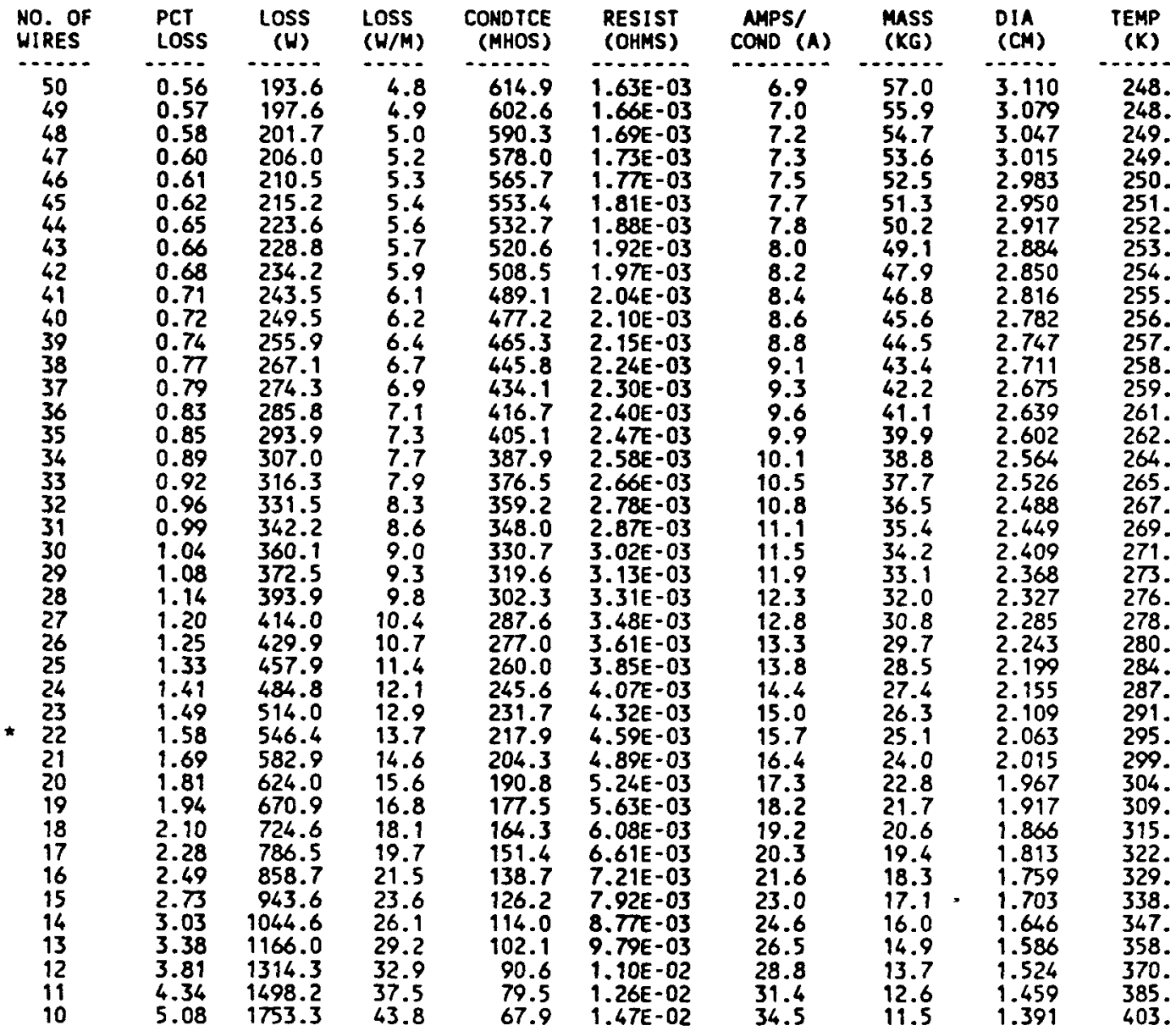

- transmission line selecteo 
30 kWe OtR, Base Case (Nov. 30, 1989)

LONEST MUCLEAR SUBSYSTEM MASS OPTION

PONER $=30.0 \mathrm{KWE}$ OPERATION TIME $=10.0$ YEARS

THERMAL EFFICIENCY $=12.6 \times$

1235. KG - MUCLEAR SUBSYSTEM MASS

537. KG - REACTOR MASS

394. KG - SHIELD MASS

2.300 - LENGTH TO DIAMETER RATIO

0.750 - INSIDE FUEL TO CORE DIAMETER RATIO

0.337 M - CORE DIAMETER

$0.776 \mathrm{M}$ - CORE LENGTH

$0.069 m^{* * 3}$ - CORE VOLUME

$123.0 \mathrm{KG}$ - ACTUAL FUEL MASS

122.3 KG - FUEL MASS BASED ON THERMIONICS

$108.5 \mathrm{KG}$ - FUEL MASS BASED ON FUEL DAMAGE

$120.1 \mathrm{KG}$ - FUEL MASS BASED ON TEMPERATURE

123.0 KG - FUEL MASS BASED ON MEUTRONICS

0.17 - MOLECULAR MOOERATOR TO FUEL RATIO

62.2 KG - COMPACTED CRITICAL MASS

0,000 KG - MASS OF FUEL BURNED UP

109. KG - MOOERATOR MASS

82. KG - MASS OF REACTOR STRUCTURE

223. KG - REFLECTOR MASS

$0.160 \mathrm{M}$ - TOTAL GAMMA SHIELD THICXNESS

$0.441 \mathrm{M}$ - TOTAL NEUTRON SHIELD THICKNESS

154. KG - NEUTRON SHIELD MASS

240. KG - GAMMA SHIELD MASS

394. KG - TOTAL SHIELD MASS

1933. $\mathrm{K}$ - II DIODE HOT SHOE TEMPERATURE

2112. K - TEMPERATURE OF THE CORE SURFACE

NEUTRON DOSE BEHJND SHIELD GAMMA DOSE BEHIND SHIELD
5.15E+15 NVT $2.57 E+08$ RAD 
30 kHe OTR, Base Case (Hov. 30, 1989)

OPERATION TIME $=10.0$ YEARS

THERMAL EFFICIENCY $=12.6 \%$

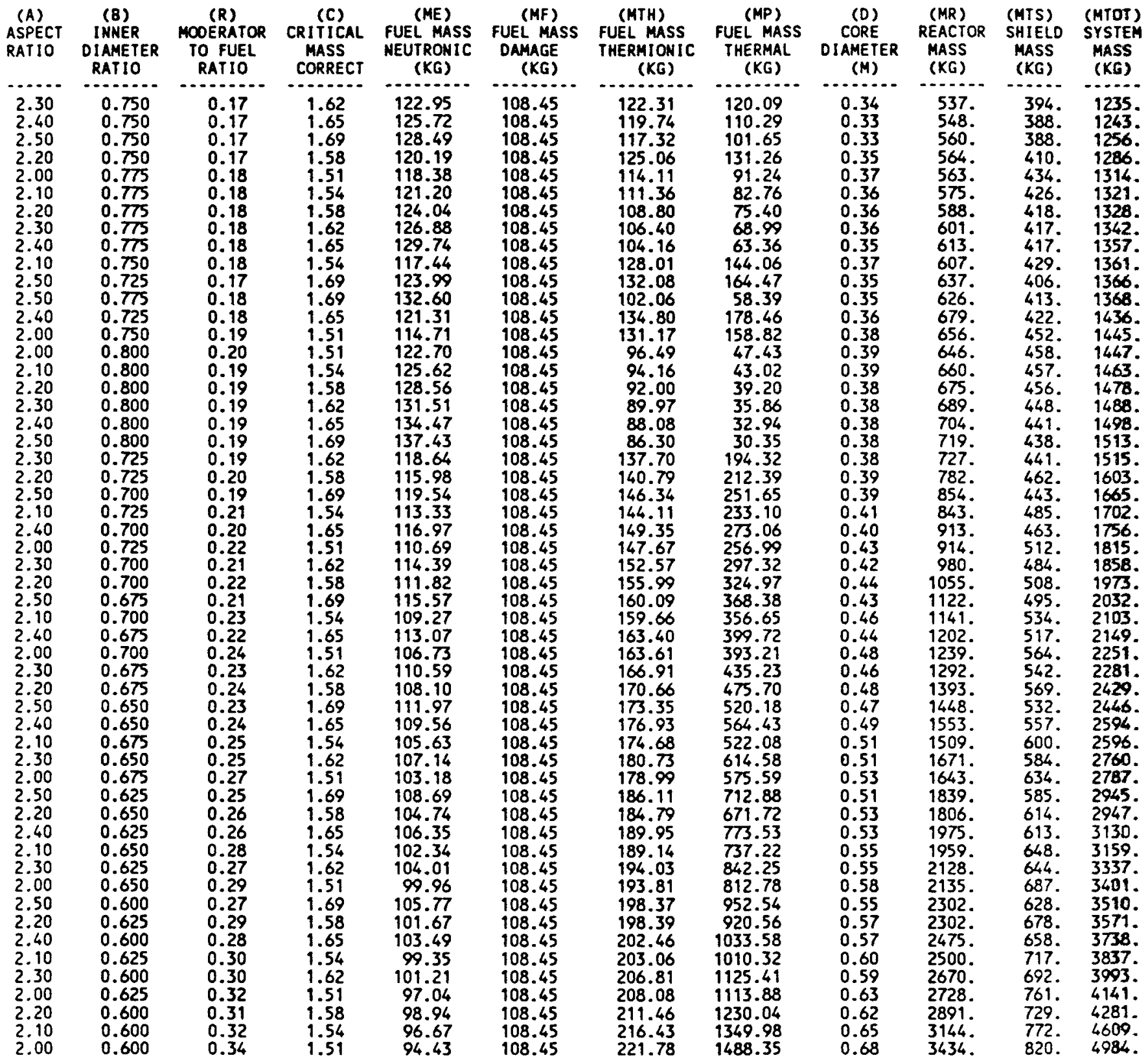


30 kHe OTR, Base Case (Nov. 30, 1989)

POUER = 30. KUE

OPERATION TIME $=10.0$ YEARS

ELECTRICAL EFFICIENCY $=13.1 \mathrm{x}$

OPTIMIZEO PONER SYSTEM MASS SUMMARY

REACTOR

$\begin{array}{lr}\text { FUEL } & 123 . \\ \text { MOOERATOR } & 109 . \\ \text { STRUCTURE } & 82 .\end{array}$

STRUCTURE $\quad 82$.

TOTAL 537.

INST \& CONTROL 216.

SAFETY SYSTEMS

RE-ENTRY SHIELD 25.

ROOS \& ORIVES 63.

TOTAL

63.

SHIELD

NEUTRON 154.

GAMMA 240

TOTAL 394.

THERMIONICS

236.

ELECTRICAL SUBSYSTEM

$\begin{array}{lr}\text { POWER COND } & 39 . \\ \text { PC RADIIATOR } & 17 . \\ \text { PC RAD SHIELD } & 3 . \\ \text { TI STRAPS } & 27 . \\ \text { TRANS LIINE } & 46 . \\ \text { TOTAL } & \end{array}$

TOTAL

131.

RADIATOR

84.

BOON

TOTAL SYSTEM

180.

1867. KG

OPTIMIZED POWER SYSTEM DIMENSION SUMMARY

REACTOR

$\begin{array}{ll}\text { CORE LENGTH } & 77.56 \mathrm{CM} \\ \text { CORE DIAMETER } & 33.72 \mathrm{CM} \\ \text { REFLECTOR THICK } & 10.00 \mathrm{cM} \\ \text { TOTAL VOLUME } & 0.221 \mathrm{M}^{* * 3}\end{array}$

SHIELO

\begin{tabular}{|c|c|}
\hline $\begin{array}{l}\text { NEUTRON THICK } \\
\text { GAMMA THICK } \\
\text { FRONT DIAMETER } \\
\text { TOTAL VOLUME }\end{array}$ & $\begin{array}{l}44.15 \mathrm{CM} \\
14.00 \mathrm{CM} \\
70.65 \mathrm{CM} \\
0.23 \mathrm{M} * * 3\end{array}$ \\
\hline MALF AMGLE & 4.7 DEG \\
\hline LENGTH & $20.0 \mathrm{M}$ \\
\hline DIATOR AREA & $4.2 \mathrm{~m} * 2$ \\
\hline RADIATOR AREA & $2.2 m * * 2$ \\
\hline
\end{tabular}

***** CaUtion: radiator does not fit above shielo *m*m 
DISTRIBUTION

Note: DOE/OSTI, UC 70059 copies.

Julio C. Acevedo

PSIO/NASA

Lewis Research Center

$21000 \mathrm{Rd}$.

Cleveland, OH 44135

Dr. C. A. Aeby

WL/NTC

Weapons Laboratory

Kirtland AFB, NM 87117

Lt. Col A. Alexander

AFSTC/SW

Kirtland AFB, NM 87117

Douglas Allen

W. J. Schafer Associates

1901 No. Ft. Myers Drive

Suite 800

Arlington, VA 22209

L. Amstutz

U.S. Army Belvoir RDE Ctr.

STRABE - FGE

Fort Belvoir, VA 22060-5606

Larry Atha

U.S. Army Strategic Defense Com.

106 Wynn Drive

Huntsville, AL 35807

Lt. Dale Atkinson

WL/NTCA

Weapons Laboratory

Kirtland AFB, NM 87117

H. S. Bailey

Manager, Systems Analysis

General Electric NSTO

310 DeGuigne Drive

Sunnyvale, CA 90486

Rick R. Balthaser

RETD

U.S. Department of Energy

Albuquerque Operations Office

Albuquerque, NM 87115
C. Perry Bankston

California Institute of Technology

Jet Propulsion Laboratory

4800 Oak Grove Drive

MS 122-123

Pasadena, CA 91109

Major W. Barattino

WL/TAS

Kirtland Air Force Base

New Mexico 87117-6002

J. O. Barner

Battelle Pacific Northwest Laboratory

P. O. Box 999

Richland, WA 99352

D. Bartine

Oak Ridge National Laboratory

P. O. Box $Y$

Bldg 9201-3, MS-7

Oak Ridge, TN 37831

Ormon Bassett

W. J. Schafer Associates 1901 No. Ft. Myers Drive

Suite 800

Arlington, VA 22209

Ms. Kathleen Batke

NASA Lewis Research Center

Research/Technology Branch

21000 Brookpark Road

MS 3350

Cleveland, OH 44135

$\mathrm{J}$. Beam

AFWRDC/POOS

Wright-Patterson Air Force Base

Ohio 45433

J.A. Belisle

Manager, Energy Programs

Grumman Aerospace Corp.

MS B20-05

Bethpage, NY 11714

DO NOT MICROFLLM

THIS PAGE 
C. Bell

Los Alamos National Laboratory

P.O. Box 1663

MS - F611

Los Alamos, NM 87545

D. Bennett

U. S. Department of Energy

NE- 521

Germantown, MD 20874

RP/Gary Bennett

NASA Headquarters

600 Independence Ave.

Washington, D.C. 20546

David Bents

NASA Lewis Research Center

21000 Brookpark Road

MS 301-5, Rm. 101

Cleveland, $\mathrm{OH} \quad 44135$

J. A. Bernard

Massachusetts Institute of Technology

1328 Albany Street

Cambridge, MA 02139

Dave Berwald

Grumman Aerospace Corporation

MS B20-05

Bethpage, NY 11714

F. Best

Assistant Professor

Texas A\&M University

Nuclear Engineering Dept.

College Station, TX 77843-3133

Mark Bezik

NASA Lewis Research Center

3160

21000 Brookpark Rd.

Cleveland, OH 44135

Samit K. Bhattacharyya

Argonne National Laboratory

9700 So. Cass Avenue

Bldg. 207

Argonne, IL 60439-4841
H. S. Bloomfield

Program Manager

NASA Lewis Research Center

MS 301-5, Rm. 103

21000 Brookpark Road

Cleveland, OH 44135

Ron Boatwright MS-L- 8030

Attn: Document Control

Martin Marietta Space Systems

P O Box 179

Denver, CO 80201

Richard J. Bohl

Los Alamos National Laboratory

MS K560

P. O. Box 1663

Los Alamos, NM 87545

James Bolander

NASA Lewis Research Center

21000 Brookpark Road

Cleveland, OH 44135

William Borger

AFWRDC/POOA

Aeronautical Laboratory

Wright Patterson AFB

Ohio 45433

S. Borowski

NASA Lewis Research Center

MS : $501-6$

21000 Brookpark Road

Cleveland, OH 44135

D. Bouska

U.S. Army Strategic Defense Command 106 Wynn Drive

Huntsville, AL 35807

T. Bowden

Brookhaven National Laboratory

P. O. Box 155

Upton, NY 11973

Robert Boyle

Garrett Fluid Systems Co.

P. 0. Box 5217

Phoenix, Arizona

\section{DO NOT MICROFILM


Mr. Dick Bradshaw

CSSD-H-SAV

US Army Strategic Defense Command

106 Wynn Drive

P. O. Box 1500

Huntsville, AL 35807-3801

Bruce Bremer

Riverside Research Institute

1701 No. Ft. Meyers Drive

Suite 700

Arlington, VA 22209

Jerry Bueck

W. J. Schafer Associates

2000 Randolph Road, SE

Suite 205

Albuquerque, NM 87106

Wade Carroll

U.S. Department of Energy

NE 52

Germantown Building

Washington, DC 20545

R. D. Casagrande

General Electric

Astro Systems

P. O. Box 8555

Philadelphia, PA

L. Cavery

SDIO/IST

Washington, DC 20301-7100

B. Chadsey

SAIC

1710 Goodridge Drive

McLean, VA 22101

T. S. Chan

General Electric

Astro Systems/SCO

P. O. Box 8555

35 T15, Bldg. 20

Philadelphia, PA 19101

John W. H. Chi

Westinghouse Electric Corp.

Advanced Energy Systems

P.O. Box 158

Madison, PA 15663
W. Chiu

General Electric

Space Systems Division

Valley Forge Space Center

P. O. Box 8555

Rm. 35T20, B1dg. 20

Philadelphia, PA 19101

Paul Chivington

TRW, Inc.

Suite 200

2340 Alamo, Se

Albuquerque, NM 87106

Lynn Cleland

Lawrence Livermore National Laboratory

P.0. Box 808

MS L- 144

Livermore, CA 94550

Robert Cooper

MS MS-241

Aerospace Corporation

P. O. Box 92957

Los Angeles, CA 90009-2957

E. P. Coomes

Battelle Pacific Northwest Laboratory

P. O. Box 999

Richland, WA 99352

Carl Cox

Westinghouse Hanford

MS $\mathrm{C}-27$

P.O. Box 1970

Richland, WA 99352

Cecil Crews

MS M5-614

Aerospace Corporation

P. 0. Box 92957

Los Angeles, CA 90009-2957

J. Crissey

W. J. Schafer Associates

1901 No. Ft. Myers Drive

Suite 800

Arlington, VA 22209

R. Dahlberg

General Atomics

P. 0. Box 85608

San Diego, CA 92138

DO NOT MICROFILM

Dist-3 
Dr. Gracie E. Davis

RAEE

HQ Defense Nuclear Agency

6801 Telegraph Road

Alexandria, VA 22213

Dan DeLong

Teledyne Brown Engineering

Cummings Research Park

Huntsville, AL 35807

R. Dewitt

Naval Surface Weapons Ctr.

Code F-12

Dahlgren, VA 22448-5000

N. Diaz

INSPI

202 NSC

University of Florida

Gainesville, FL 32611

P. W. Dickson

EG\&G Idaho, Inc./INEL

P. O. Box 1625

Idaho Falls, ID 83415

P. J. Dirkmaat

U.S. Department of Energy/Idaho 785 DOE Place

Idaho Falls, ID 83402

J. DiTucci

AF Space Technology Ctr.

SWL

Kirtland AFB, NM 87117-6008

M. P. Dougherty

Martin Marietta Corporation

Astronautics Group

Space Systems

P.O. Box 179

Denver, CO 80201

Rudy Duscha

NASA Lewis Research Center

PSIO

21000 Brookpark Rd.

Cleveland, OH 44135
Mr. Richard Dudney

CSSD - H-YA

US Army Strategic Defense Command 106 Wynn Drive

P. 0. Box 1500

Huntsvil1e, AL 35807-3801

D. S. Dutt

Manager, Fuel Design

Westinghouse Hanford

Engineering Development Lab.

P. O. Box 1970

Richland, WA 99352

G. Edlin

U.S. Army Strategic Defense Cm.

106 Wynn Drive

Huntsville, AL 35807

R. L. Eilbert

Naval Research Laboratory

Washington, DC 20375-5000

M. E1-Genk

University of New Mexico

Chemical and Engineering Department

Albuquerque, NM 87131

Jeffrey George

MS 501-6

NASA Lewis Research Center

21000 Brookpark Road

Cleveland, Ohio 44135

David M. Ericson

ERC

1717 Louisiana NE

Suite 202

Albuquerque, NM 87110

D. Escher

TRW

One Space Park

Redondo Beach, CA 90278

J. Farber

Defense Nuclear Agency

RAEV

6801 Telegraph Road

Alexandria, VA 22310-3398

\section{DO NOT MICROFILM


G. Farbman

Westinghouse

Advanced Energy Systems Division

P. O. Box 158

Madison, PA 15663

D. C. Fee

Argonne National Laboratory

9700 S. Cass Avenue

Argonne, IL 60439

M. Firmin

Aerospace Corporation

P.O. Box 9113

Albuquerque, NM 87119

C. Fisher

GA Technologies

P. O. Box 85608

San Diego, CA 92138

T. Fitzgerald

TRW

One Space Park

Redondo Beach, CA 90278

Terry Flannagan

JAYCOR

11011 Torreyana Road

P.O. Box 85154

San Diego, CA 92138-9259

Dr. Dennis Flood

NASA Lewis Research Center

Mail Stop: 302-1

2100 Brookpark Road

Cleveland, Ohio 44135

J . Foster

Defense Nuclear Agency

RAEV

6801 Telegraph Road

Alexandria, VA 22310-3398

E. P. Framan

California Inst. of Technology

Jet Propulsion Lab.

4800 Oak Grove Drive

MS 301-285

Pasadena, CA 91109
Dr. Mike Frankel

SPAS

HQ Defense Nuclear Agency

6801 Telegraph Road

Alexandria, VA 22213

Robert Frank1in

U.S. Army Strategic Defense $\mathrm{Cm}$ 106 Wynn Drive

Huntsville, AL 35807

Bob Gardner

Mission Research Corporation

1720 Randolph Road, SE

Albuquerque, NM 87106-4245

James Garner

TRW

One Space Park

Redondo Beach, CA 90278

Dr. James Gee

MS M7-633

Aerospace Corporation

P. O. Box 92957

Los Angeles, CA 90009-2957

Jeffrey George

MS : $501-6$

NASA Lewis Research Center

21000 Brookpark Rd.

Cleveland, OH 44135

R. Giellis

Martin Marietta Corp.

P. O. Box 179

MS 0484

Denver, CO 80201

B. Glasgow

TRW-ATD

One Space Park

Redondo Beach, CA 90278

Lt. M. Good

Air Force Space Technology Center TP

Kirtland Air Force Base

New Mexico, 87117-6008

Capt. J. Gray

WL/NTCA

Weapons Laboratory

Kirtland AFB, NM 87117 
R. Gray

RADC/OCTP

Griffis Air Force Base

New York 13441

R. Gripshoven

Naval Surface Weapons Center

F12

Dahlgren, VA 22448-5000

R. L. Hammel

Product Line Manager

Spacecraft Engineering Division

TRW

One Space Park

Bldg. R-4/2190

Redondo Beach, CA 90278

$R$. Hammond

SDIO/DE

Washington, DC 20301-7100

W. R. Hardie

Deputy Group Leader

Los Alamos National Laboratory

MS F611

P. O. Box 1663

Los Alamos, NM 87545

Neal Harold

AFWAL/POOC - 1

Wright-Patterson AFB

Ohio 45433-6563

Mr. Charlie D. Harper

CSSD - H-YA

US Army Strategic Defense Command

106 Wynn Drive

P. O. Box 1500

Hunstville, AL 35807-3801

Dr. M. Harrison

WL/NTCA

Weapons Laboratory

Kirtland AFB, NM 87117

S. Harrison

Office of Science \& Technology

Executive Office of the President

Mailing Room 5013

New Executive Office Bldg.

Washington, DC 20506

\section{DO NOT MICROFILM} THIS PAGE
K. C. Hartkay

ANSER Corporation

Crystal Gateway 3

1225 Jefferson Davis Highway $\# 800$

Arlington, VA 22208

J. K. Hartman

U. S. Department of Energy

San Francisco Operations office

1333 Broadway Avenue

Oakland, CA 94612

L. Hatch

Rasor Associates

253 Humboldt Ct.

Sunnyvale, CA 94089

Col. C. Heimach

U. S. Air Force

$\mathrm{SD} / \mathrm{XR}$

P.O. Box 92960 WPC

Los Angeles AFB

CA 9009-2960

I. Helms

U. S. Department of Energy

NE -54

Washington, DC 20545

J. W. Henscheid

EG\&G Idaho, Inc./INEL

P. O. Box 1625

Idaho Falls, ID 83415

Mr. R. Herndon

AFSTC/SWL

Kirtland AFB, NM 87117

Lt. Col. C. Hill

SDIO/INK

Pentagon, Rm $1 E 178$

Washington, DC 20301-7100

J . Hipp

$\mathrm{S}$-Cubed

2501 Yale Blvd., SE

Suite 300

Albuquerque, NM 87106

J. Hnat

General Electric

Astro Systems

P. 0. Box 8555

B1dg. 100, Rm. M2412

Philadelphia, PA 19101 
E. E. Hoffman

U. S. Department of Energy

Oak Ridge Operations Office

P. O. Box E

Oak Ridge, TN 37830

H. W. Hoffman

Oak Ridge Nat'1 Lab.

P.O. BoX X

Oak Ridge, TN 37831

K. W. Hoffman

Air Force Foreign

Technology Division

TDTQ

Wright-Patterson AFB

Ohio 45433

R. L. Holton

U.S. Department of Energy

ALO/ETD

P.O. Box 5400

Albuquerque, NM 87115

J. L. Hooper

U. S. Department of Energy

Chicago Operations Office

9800 So. Cass Avenue

Argonne, IL 60439

CNSE/Capt. Howard

Space Systems Division

P. O. Box 92960

Worldway Postal Center

Los Angeles, CA 90009-2960

A. Huber

Air Force Space Technology Center XLP

Kirtland Air Force Base

New Mexico 87117-6008

A. K. Hyder

W. J. Schafer Associates

1901 No. Ft. Myers Drive

Suite 800

Arlington, VA 22209

Dr. T. Hyder

Auburn University

202 Sanform Hall

Auburn, AL 36849-3501
L. Isenberg

California Institute of Technology

Jet Propulsion Laboratory

4800 Oak Grove Drive

MS 264-770

Pasadena, CA 91109

D. E. Jackson

BDM Corporation

1801 Randolph Rd., SE

MS BV-24

Albuquerque, NM 87106

Jerry Jaggers

Attn: Document Control

for Bldg. 593

Lockheed Missiles and

Space Co. Inc.

P O Box 3504

Sunnyvale, CA 94088

Frank Jankowski

WL/TAPN

Kirtland AFB, NM 87117

Marshall Jew (MS: A02-105)

Grumman Aerospace Corporation

CDC (Ms: A04-35)

Bethpage, NY 11714

B. M. Johnson

Batelle Pacific Northwest Lab.

P.0. Box 999

Richland, WA 99352

R. Johnson

Rocket Dyne

HB -13

6633 Canoga Ave.

Canoga Park, CA 91303

A. Juhasz

NASA Lewis Research Center

MS 301-5, Rm. 101

21000 Brookpark Road

Cleveland, OH 44135

Col. John A. Justice

WL/NTN

Weapons Laboratory

Kirtland AFB, NM 87117 
Ehsan Kahn

BDM Corp.

7915 Jones Branch Dr.

MS West Brach 5B37

McLean, VA 22102-3396

Robert Karcher, MS EA-22

Rockwe11 Int'1 Space Transportation

Systems Division

12214 Lakewood Blvd.

Downey, CA 90241

W. Y. Kato

Deputy Chairman

Brookhaven National Laboratory

P. O. Box 155

Upton, NY 11973

R. J . Katucki

Manager, Space Power Programs

General Electric Company

Astro Systems

P. O. Box 8555

Philadelphia, PA 19101

D. Kelleher

Technical Director

Advanced Technology Division

AFWRDC/AW

Kirtland Air Force Base

New Mexico 87117

Peter Kemmey

DARPA

1400 Wilson Blvd.

Arlington, VA 22209

Lt. E. B. Kennel

AFWRDC/POOS

Bldg. 450

Wright Patterson AFB

Ohio 45433

K. Kennerud

Boeing Company

Boeing Aerospace System

P.O. Box 3707

Seattle, WA 98124

O. F. Kimbal1

Oak Ridge Nat' 1 Lab.

P.O. Box 2009

B1dg. 4508, MS 080

Oak Ridge, TN 37831-6080

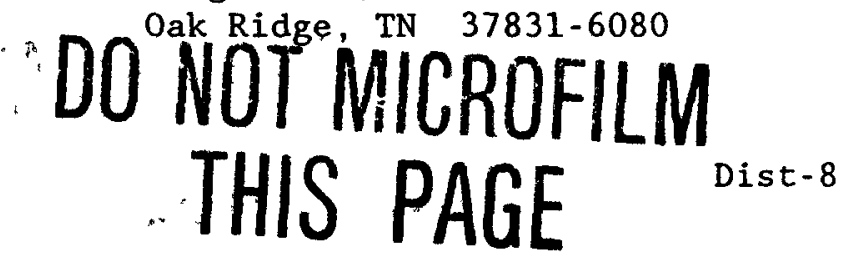

F. King

U. S. Army Defense Command 106 Wynn Drive

Huntsville, AL 35807

W. L. Kirk

Los Alamos National Laboratory

P. O. Box 1663

Los Alamos, NM 87545

A. Klein

Oregon State University

Dept. of Nuclear Engineering

Corvallis, Oregon 97331

J . Krupa

U. S. Department of Energy

SAN-ACR Division

1333 Broadway

Oakland, CA 94612

K. D. Kuczen

Argonne National Laboratory

97000 So. Cass Avenue

Argonne, IL 60439

Gerald Kulcinski

University of Wisconsin

Fusion Technology Institute

1500 Johnson Drive

Madison, WI 53706-1687

A. S. Kumar

University of Missouri-Rolla

Department of Nuclear Energy

220 Engineering Research Lab.

Rolla, MO 65401-0249

W. Lambert

U. S. Department of Energy

SAN-ACR Division

1333 Broadway

Oakland, CA 94612

Dick Lancashire

PSIO/NASA

Lewis Research Center

21000 Brookpark Rd.

Cleveland, $\mathrm{OH} 44135$

S. J. Lanes

Deputy Director

Breeding Reactor Program

U. S. Department of Energy

Washington, DC 20545 
Lt. Col. F. Lawrence

HQ ASFPACECOM/XPXIS

Peterson Air Force Base

Colorado 80914-5001

R. J . LeClaire

Los Alamos National Laboratory

P. O. Box 1663

MS F611

Los Alamos, NM 87545

CNIS/Lt. Col. J. Ledbetter

Space Systems Division

P. O. Box 92960

Worldway Postal Center

Los Angeles, CA 90009-2960

J. P. Lee

U. S. Department of Energy

MS MA- 206

Washington, DC 20545

Dr. James Lee

SDIO/TNK

Washington, D.C. 20301-7100

Strategic Defense Initiative Org.

The Pentagon

Attn: Dr. James Lee

Washington, DC 20301-7100

Lt. Col. R. X. Lenard

SDIO/KE

The Pentagon

Washington, DC 20301-7100

S. Levy

U. S. Army ARDC

Building 329

Picatinny Arsenal

New Jersey 87806-5000

R. A. Lewis

Argonne Nat'1 Lab.

9700 So. Cass Avenue

Argonne, IL 60439

Larry Long

Westinghouse R\&D

1310 Beulah Road

Bldg. 501-3Y56

Pittsburgh, PA 15235
L. H. Luessen

Naval Surface Weapons Center

Code F12

Dahlgren, VA 22448-5000

Bruce MacCabee

$\mathrm{R} / 42$

Naval Surface Weapons Laboratory

White Oaks

Silver Springs, MD 20910

Phil Mace

W. J. Schafer Associates

1901 North Ft. Myers Drive

Suite 800

Arlington, VA 22209

P. Mahadevan

MS M7-597

Aerospace Corporation

Po box 92957

Los Angeles, CA 90009-2957

T. Mahefky

Group Leader, Thermal Systems

AFWRDC

Aeronautical Laboratory

Wright Patterson Air Force Base

Ohio 45433

B. J. Makenas

Westinghouse Hanford Company

P. O. Box 1970

Richland, WA 99352

P. Margolis

Aerospace Corporation

P. O. Box 92957

E1 Segundo, CA 90009

Charles Martin

U. S. Department of Energy

NE -54

F415/GTN

Germantown, MD 20545

Lee Mason

NASA Lewis Research Center

MS : $501-6$

21000 Brookpark Road

Cleveland, $\mathrm{OH} 44135$ 
L. D. Massie

AFWRDC/POOC - 1

Aeronautical Laboratory

Bldg. 450

Wright-Patterson AFB

Ohio 45433

Bill Matoush

AFSPACESOM/XPXY

Peterson AFB

Colorado Springs, co 80915-5001

Tom McComas

NASA Lewis Research Center/UF

21000 Brookpark Rd.

Cleveland, $\mathrm{OH} 44135$

Maj. Tom McDowel1

SDIO/INK

Pentagon, Rm $1 E 178$

Washington, DC 20301-7100

Glen McDuff

Texas Tech. University

Dept. of Electrical Engr.

Lubbock, TX 79409

Barbara McKissock

NASA Lewis Research Center

MS 301-5

21000 Brookpark Road

Cleveland, OH 44135

D. McVay

United Technologies

International Fuel Cells

195 Governor's Highway

So. Windsor, CT 06074

M. A. Merrigan

Los Alamos National Laboratory

P. 0. Box 1663

Los Alamos, NM 87545

Ira Merritt

CSSD-H-LS

US Army Strategic Defense Command 106 Wynn Drive

P. 0. Box 1500

Huntsville, AL 35807-3801

B. Meyers

Naval Space Command

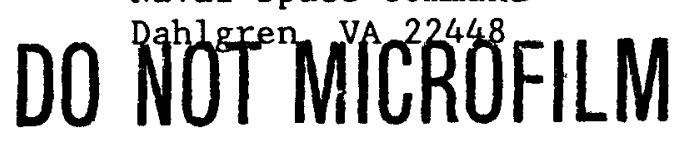

THIS. PAGE Dise-10
J. Metzger

Los Alamos National Laboratory

P. 0. Box 1663

Los Alamos, NM 87545

Tom Miller

ASAO/NASA

Lewis Research Center

21000 Brookpark Rd.

Cleveland, OH 44135

J. Mims

S-Cubed

2501 Yale Blvd., SE

Suite 300

Albuquerque, NM 87106

J. F. Mondt

Deputy Project Manager

California Institute of Technology

Jet Propulsion Laboratory

4800 Oak Grove Drive

Pasadena, CA 91109

Capt. J. Moody

AFSTC/SWW

Kirtland AFB, NM 87117

J. C. Moyers

Oak Ridge National Laboratory

P. O. Box Y

Bldg. 9201-3, MS -7

Oak Ridge, TN 37831

D. M. Mulder

AFWL/TAPN

Kirtland Air Force Base

New Mexico 87117-6008

Mr. J. Mullis

WL/NTCA

Weapons Laboratory

Kirtland AFB, NM 87117

I. T. Myers

NASA Lewis Research Center

MS 301-2, Rm. 116

21000 Brookpark Road

Cleveland, $\mathrm{OH} 44135$

Joseph Nainiger

MS 501-6

NASA Lewis Research Center

21000 Brookpark Road

Cleveland, OH 44135 
D. F. Nichols

AFWL/TAPN

Kirtland AFB

NM 87117-6008

J. P. Nichols

Oak Ridge National Laboratory

Bldg. K-1030, Room 110

P. O. Box 2003

Oak Ridge, TN 37831-7312

M. Nikolich

W. J. Schafer Associates

1901 No. Ft. Myers Drive

Suite 800

Arlington, VA 22209

Commander R. Nosco

Naval Space Command

Dahlgren, VA 22448

George Novak

Cost Analysis Org.

NASA/Lewis Research Center

21000 Brookpark Rd.

Cleveland, OH 44135

Capt. P. D. Nutz

USAF-SD/CNSD

P.O. Box 92960

LA-AFS

Los Angeles, CA 90009-2960

C. Oberly

AFWRDC/POOC - 1

Wright-Patterson AFB

Ohio 45433

M. Olszewski

Oak Ridge National Laboratory

P. O. BoX Y

Oak Ridge, TN 37831

D. Palac

NASA Lewis Research Center

MS : $501-6$

21000 Brookpark Road

Cleveland, OH 44135

Dr. D. Payton

EOS Technologies Inc.

200 Lomas NW, Suite 1121

Albuquerque, NM 87102
Capt. G. Peredo

U. S. Air Force

$\mathrm{SD} / \mathrm{XR}$

P.O. Box 92960 WPC

Los Angeles AFB

CA 9009-2960

Ed Peterson

Code 4611

Naval Research Laboratory

4555 Overlook Drive

Washington, DC 20375-5000

W. Portnoy

Texas Tech University

Dept of Electrical Engineering

Lubbock, TX 79409

J. Powell

Office of Reactor Systems

Brookhaven National Laboratory

MS 820M, Bldg. 701, Level 143

P. O. Box 155

Upton, NY 11973

J. L. Preston, Jr.

United Technologies

International Fuel Cells

195 Governor's Highway

South Windsor, CT 06074

Eric Proust

Commissariat A L'Energie Atomique

Dept. des Etudes Mechaniques

et Thermiques

IRDI/DEDR/DEMT/SERMA

C.E.N. Saclay

91191 Gif-Sur-Yvette Cedex

France

Lt. Col. H. Pugh

AFSTC/SWL

Kirtland AFB, NM 87117

C. Purvis

NASA Lewis Research Center

MS 302-1, Rm. 101

21000 Brookpark Road

Cleveland, $\mathrm{OH} 44135$

C. Quinn

U. S. Department of Energy

ALO/ETD

P. O. Box 5400

Albuquerque, NM 87115 
William A. Ranken

Los Alamos National Laboratory

Mail Stop: E552

P. O. Box 1663

Los Alamos, NM 87545

N. Rasor

Rasor Associates

253 Humboldt Ct.

Sunnyvale, CA 94089

D. Reid

Los Alamos National Laboratory MS $\mathrm{H} 811$

P. O. Box 1663

Los Alamos, NM 87545

CNBSS/Maj . L. Rensing

Space Systems Division

P. O. Box 92960

Worldway Postal Center

Los Angeles, CA 90009-2960

Dick Renski

AFWRDC/AA

Wright-Patterson AFB

Ohio 45433

J. R. Repp

Westinghouse R\&D

1310 Beulah Road

Bldg. 501-3Y56

Pittsburgh, PA 15235

W. H. Roach

$S$-Cubed

2501 Yale Blvd., SE

Suite 300

Albuquerque, NM 87106

Carlos D. Rodriquez

ASAO/NASA

Lewis Research Center

21000 Brookpark Rd.

Cleveland, $\mathrm{OH} 44135$

Frank Rose

Auburn University

Space Power Institute

231 Leach Center

Auburn, AL 36849-3501

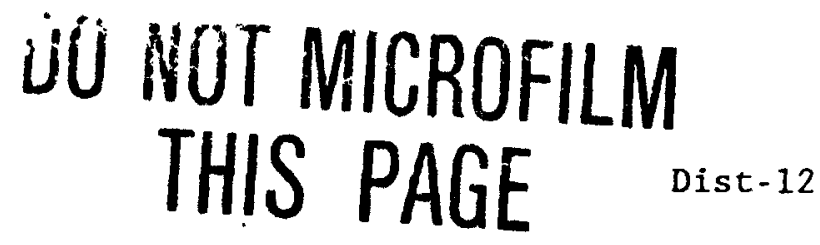

J. H. Saloio

ERC

1717 Louisiana NE

Suite 202

Albuquerque, NM 87110

S. L. Samuelson

U. S. Department of Energy

San Francisco Operations Office 1333 Broadway Avenue

Oakland, CA 94612

R. T. Santoro

Oak Ridge National Laboratory

P. O. Box 22008

Oak Ridge, TN 37831-6363

W. J. Sarjeant

State University of New York at

Buffalo

Dept. of Electrical Engineering

312 Bonner Avenue

Buffalo, NY 14260

Mike Saunders

Booz-Allen and Hamilton Inc.

4330 East-West Highway

Bethesda, MD 20814

L. Schmid

Assistant Project Manager

Battelle Pacific Northwest Lab.

P. O. Box 999

Richland, WA 99352

Paul Schmitz

MS : 301-5

NASA Lewis Research Center

21000 Brookpark Road

Cleveland, $\mathrm{OH} 44135$

Lt. Col. Schneider

WL/NTC

Weapons Laboratory

Kirtland AFB, NM 87117

Col. Garry Schnelzer

SDIO/SATKA

Washington, DC 20301-7100

A. D. Schnyer

NASA Headquarters

Room 600, Code: RP

600 Independence Ave., SW

Washington, DC 20546 
A. D. Schonfeld

TRW

One Space Park

Redondo Beach, CA 90278

Co1. J. Schofield

SDIO/SY

Washington, DC 20301-7100

J. Scholtis

Directorate of Nuclear Safety AFISC/SN

DET 1, AFISC/SNRA

Kirtland AFB

New Mexico 87117-5000

M. J. Schuller

WL/TAPN

Kirtland Air Force Base

New Mexico 87117-6008

G. Schwarze

NASA Lewis Research Center

MS 301-2, Rm. 117

21000 Brookpark Road

Cleveland, $\mathrm{OH} 44135$

Jim Scott

Los Alamos National Laboratory

Mail Stop: E552

P. O. Box 1663

Los Alamos, NM 87545

Clarence Severt

AFWRDC/POOC - 1

Wright-Patterson AFB

Ohio 45433-6563

Major Seward

AFWRDC/POOC

Aeronautical Laboratory

Bldg. 18

Wright Patterson Air Force Base

Ohio 45433

D. C. Sewe1l

DCSCON Consulting

4265 Drake Court

Livermore, CA 94550

C. Sharn

SDIO/SY

Washington, DC 20301-7100
B. J. Short

Babcock \& Wilcox

Nuclear Power Division

3315 old Forest Road

P.O. Box 10935

Lynchburg, VA 24506-0935

M. Simon-Tov

Oak Ridge Nat' 1 Lab.

Bldg. 9201-3, MS-7

Oak Ridge, TN 37831

CNIWT/Capt. Simpson

Space Systems Division

P. O. Box 92960

Worldway Postal Center

Los Angeles, CA 90009-2960

Dr. B. K. Singaraju

WL/NTCA

Weapons Laboratory

Kirtland AFB, NM 87117

Henry Smith

Nichols Research Corp.

4040 So. Memorial Pkwy

Huntsville, AL 35802

John Smith

NASA Lewis Research Center

MS 301-5

21000 Brookpark Road

Cleveland, $\mathrm{OH} 44135$

S. Solomon

Aerospace Corp.

P. O. Box 92957, MS: M1-131

Los Angeles, CA 90009-2957

R. J . Sovie

NASA Lewis Research Center

MS 301-5, Rm. 105

21000 Brookpark Road

Cleveland, $\mathrm{OH} \quad 44135$

0 . Spurlock

NASA Lewis Research Center

MS 501-6

21000 Brookpark Road

Cleveland, OH 44135 
G. Staats

U. S. Department of Energy

Pittsburgh Energy Tech. Center PM-20

P. O. Box 18288

Pittsburgh, PA 15236

M. L. Stanley

EG\&G Idaho, Inc./INEL

P. O. Box 1625

Idaho Falls, ID 83415

Steve Stevenson

NASA Lewis Research Center

ASAO

21000 Brookpark Rd.

Cleveland, $\mathrm{OH} \quad 44135$

D. C. Straw

W. J. Schafer Associates

2000 Randolph Road, SE

Suite 205

Albuquerque, NM 87106

O. Spurlock

NASA Lewis Research Center

MS : $501-6$

21000 Brookpark Road

Cleveland, $\mathrm{OH} \quad 44135$

T. P. Suchocki

Los Alamos National Laboratory P. O. Box 1663

Los Alamos, NM 87545

L. H. Sullivan

Los Alamos National Laboratory

P. O. Box 1663

Los Alamos, NM 87545

\section{A. Sutey}

Spacecraft Subsystems

Boeing Company

P. O. Box 999

MS $8 \mathrm{~K}-30$

Seattle, WA 98124-2499

D. W. Swallom

AVCO Research Laboratory

2385 Revere Beach Parkway

Everett, Mass. 02149

Major P. Talty

HQ USAF/RD-D
Owen Taylor

Westinghouse R\&D

1310 Beulah Road

Bldg. 501-3Y56

Pittsburgh, PA 15235

Charles Terre11

AFWRDC/TA

Kirtland AFB,

NM 87117-6008

R. Thibodeau

AFWRDC / POOC - 1

Bldg. 450

Wright Patterson Air Force Base

Ohio 45433

J. C. Trocciola

United Technologies

International Fuel Cells

195 Governor's Highway

South Windsor, CT 06074

V. C. Truscello

California Institute of Technology

Jet Propulsion Laboratory

4800 Oak Grove Drive

Bldg. 264-770

Pasadena, CA 91109

John Uecke

S-Cubed

Suite 300

2501 Yale Blvd., SE

Albuquerque, NM 87106

T. H. Van Hagan

General Atomics

10955 John Jay Hopkins Dr.

P. O. Box 85608

San Diego, CA 92121-1194

G. B. Varnado

Int'1 Energy Associates Ltd.

1717 Louisiana NE

Suite 202

Albuquerque, NM 87110

R. Verga

SDI Organization

The Pentagon

Washington, DC 20301-7100 
I. M. Vitkovitsky

Naval Research Laboratory

Washington, DC 20375-5000

Susan Voss

Department of Energy

Room GA093

1000 Independence Ave., SW

Washington, DC 20585

D. C. Wade

Applied Physics Division

Argonne National Laboratory

9700 So. Cass Avenue

Argonne, IL 60439

John Wagner

SAIC

2109 Air Park Road, SE

Albuquerque, NM 87106

E. J. Wahlquist

U. S. Department of Energy

NE -54

F415/GTN

Germantown, MD 20545

C. E. Walter, P.E.

Lawrence Livermore National Lab.

P. O. Box 808

MS L-144

Livermore, CA 94550

J . Warren

U. S. Department of Energy

$\mathrm{NE}-52$

GTN

Germantown, MD 20545

C. W. Watson

Los Alamos National Laboratory

MS $\mathrm{F} 607$

P. 0. Box 1663

Los Alamos, NM 87545

Robert C. Webb

RAEE

HQ Defense Nuclear Agency

6801 Telegraph Road

Alexandria, VA 22213
R. Weed

Nichols Research Corporation

2340 Alamo SE

Suite 105

Albuquerque, NM 87106

Eric Wennas

JAYCOR

11011 Torreyana Road

P. 0. Box 85154

San Diego, CA 92138-9259

J. R. Wetch

President

Space Power, Inc.

1977 Concourse Drive

San Jose, CA 95131

J. F. Wett

Space \& Defense Program

Westinghouse

Advanced Energy Systems Div.

Route 70, Madison Exit

Madison, PA 15663

J . F. Whitbeck

EG\&G Idaho, Inc./INEL

P. O. Box 1625

Idaho Falls, ID 83415

Dan Whittener

U.S. Army Strategic Defense Cm.

106 Wynn Drive

Huntsville, AL 35807

R. D. Widrig

Human Factors Projects

Battelle Pacific Northwest Laboratory

P. O. Box 999

Richland, WA 99352

F. W. Wiffen

Oak Ridge National Laboratory

P. O. Box Y

B1dg. $9201-3$, MS -7

Oak Ridge, TN 37831

Major J. Wiley

Naval Space Command

N5

Dahlgren, VA 22448

Robert Wiley

5998 Camelback Lane

Columbia, MD 21045 
E. L. Wilkinson

U. S. Army Strategic Defense Command 106 Wynn Drive

Huntsville, AL 35807

N. Wilson

U. S. Army Lab. Com.

SLKET/ML

Pulse Power Technology Branch

Ft. Monmouth, NJ 07703-5000

Jerry Winter

NASA Lewis Research Center

21000 Brookpark Road

Cleveland, OH 44135

William Wright

Ballena Systems Corporation

1150 Ballena Blvd., Suite 210

Alameda, CA 94501

T. S. Wuchte

AFWL/TAPN

Kirtland AFB

NM 87117-6008

E. R. Zercher

Martin Marietta Corporation

MS L8060

P. O. Box 179

Denver, CO 80201

J. Zielinski

U. S. Department of Energy

SAN-ACR Division

13333 Broadway

Oakland, CA 94612

G. L. Zigler

Science \& Engineering Associates

6301 Indian School NE

Albuquerque, NM 87110

\section{DO NOT MICROFILM THIS PAGE}




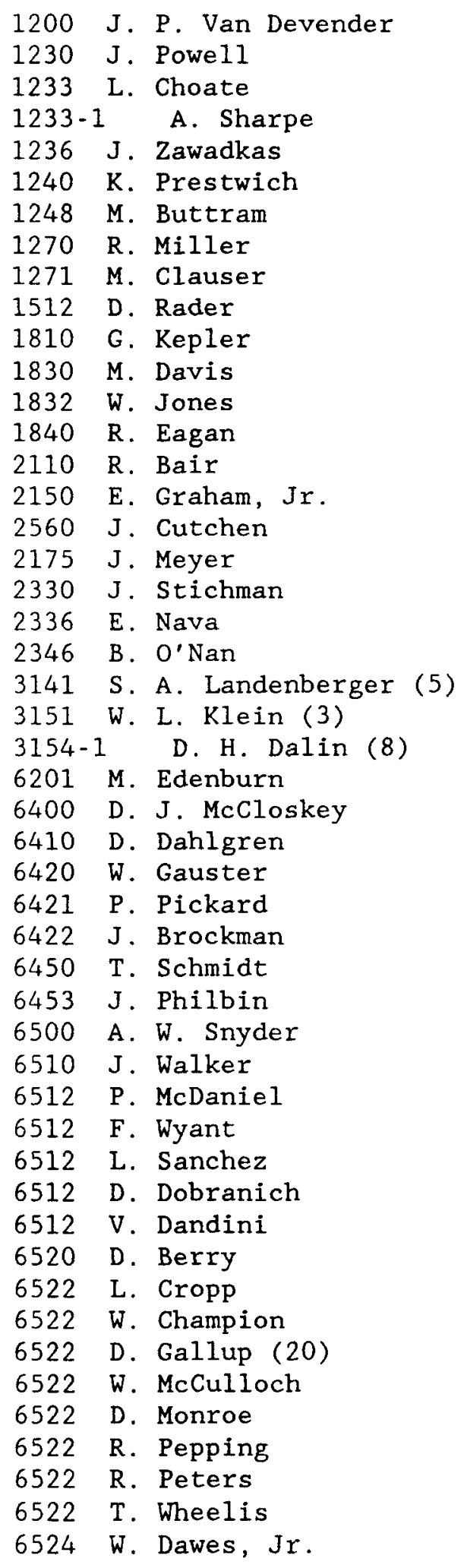

8400 R. Wayne

8524 J. A. Wackerly

9000 R. Hagengruber

9010 W. Hines

9012 J. Keizur

9012 R. Zazworski

9015 R. Preston

9100 R. Clem

9110 P. Stokes

9140 D. Rigali

9320 M. Navatril

9321 B. Boyer

9340 W. Beezhold

$9350 \mathrm{~J}$. Reinken

9351 F. Hartman 